\title{
Malacological news from the Czech and Slovak Republics in 2015-2019
}

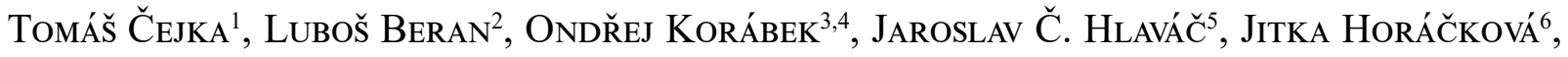 \\ Radovan Coufal ${ }^{7}$, Magda Drvotová ${ }^{8}$, Michal Mañas 9 , Veronika Horsáková ${ }^{7} \&$ Michal $^{2}$ \\ HORSÁK $^{7}$
}

This paper, the first in upcoming series, is dedicated to the memory of our great teacher Vojen Ložek.

\author{
${ }^{1}$ Institute of Botany, Plant Science and Biodiversity Centre, Slovak Academy of Sciences, Dúbravská cesta 9, SK-84523 Bratislava, \\ Slovakia,e-mail:t.cejka@gmail.com, (D) https://orcid.org/0000-0002-6485-5660 \\ ${ }^{2}$ Nature Conservation Agency of the Czech Republic, Regional Office Kokorínsko - Máchi̊v kraj Protected Landscape Area \\ Administration, Česká 149,CZ-27601 Mělník,Czech Republic, e-mail: lubos.beran@nature.cz, \\ (D) https://orcid.org/0000-0002-5851-6048 \\ ${ }^{3}$ Department of Ecology, Faculty of Science, Charles University, Viničná 7, CZ-128 44 Praha 2, Czech Republic, \\ email: ondrej.korabek@gmail.com, (D) https://orcid.org/0000-0002-2522-9165 \\ ${ }^{4}$ Nature Conservation Agency of the Czech Republic, Kaplanova 1931/1, CZ-148 00 Praha 11 - Chodov, Czech Republic \\ ${ }^{5}$ National Museum Prague, Department of Zoology, Cirkusová 1740, CZ-193 00 Praha 9 - Horni Počernice, Czech Republic, \\ e-mail: jaroslav.hlavac@nm.cz \\ ${ }^{6}$ Department of Land Use and Improvement, Faculty of Environmental Sciences, Czech University of Life Sciences Prague, \\ Kamýcká 129, CZ-16500 Prague 6 - Suchdol, Czech Republic, e-mail: jitka.horackova@gmail.com, \\ (D) https://orcid.org/0000-0003-3776-041X \\ ${ }^{7}$ Department of Botany and Zoology, Faculty of Science, Masaryk University, Kotlářská 2, CZ-61137 Brno, Czech Republic, \\ e-mails: radovan.coufal39@seznam.cz, (1) https://orcid.org/0000-0002-5870-5041; \\ veronika.horsakova@seznam.cz, (i) https://orcid.org/0000-0002-3264-7728; \\ horsak@sci.muni.cz, (D) https://orcid.org/0000-0003-2742-2740 \\ ${ }^{8}$ Department of Zoology, Faculty of Science, Charles University, Viničná 7, CZ-12844 Praha 2, Czech Republic, \\ e-mail: magda.drvotova@seznam.cz \\ ${ }^{9}$ Táboritů 23, Olomouc, CZ-77900, Czech Republic, e-mail: michal.manas@tiscali.cz, (1) https://orcid.org/0000-0003-2697-5140
}

Č́ejka T., Beran L., Korábek O., Hlaváč J. Č., Horáčková J., Coufal R., Drvotová M., Mañas M., Horsákoví V. \& Horsák M., 2020: Malacological news from the Czech and Slovak Republics in 2015-2019. - Malacologica Bohemoslovaca, 19: 71-106. Online serial at $<\mathrm{http}: / /$ mollusca.sav.sk $>18$-Oct-2020. Corrected 26-Oct-2020.

\begin{abstract}
Since the last comprehensive overview of the Czech and Slovak mollusc fauna, released in 2013, several records of species new for the countries or particular regions have appeared. In this paper, we summarize all such records and news collected in 2015-2019, including those affecting nomenclature and the national Check-lists made in 2013 and 2014. The rules for the selection of the records are: (i) the first record in Bohemia, Moravia or Slovakia, (ii) regionally important new records, (iii) records of species listed in NATURA 2000 and the national Red-lists as either critically endangered or endangered species, and (iv) currently spreading non-native species. New records are briefly commented and summarized for each species separately. Location data are published with all details in a supplementary table and are freely accessible.
\end{abstract}

Key words: mollusc fauna, faunistic survey, species list

\section{Introduction}

Starting with this contribution, we would like to continue the useful tradition of occasional publication of malacological news from the Czech and Slovak Republics, which was introduced in 1947 by the famous Czech malacologist LožEK (e.g. 1947, 1960). The latest comprehensive work dealing with Slovak mollusc fauna summarizes all published and collection data from 1945 to 1982 (LISICKÝ 1991). The next bulk of malacological news, coming again from Slovakia after nearly a quarter century, reported 14 newly recorded species (ČEJKA et al. 2006). The last comprehensive monograph commenting all known species of the Czech and Slovak fauna was published in 2013
(HorsÁK et al. 2013). Since then, changes in nomenclature and national Check-lists are monitored and provided in an online check-list (HorsáK, ČEJKA et al. 2020).

This paper primarily focus on faunistic news conducted between 2015-2019, but including also some important news from 2013-2014. The following contributions will have an annual periodicity.

The rules for the selection of the records are: (i) the first record in Bohemia, Moravia or Slovakia, (ii) regionally important new records, (iii) records of species listed in NATURA 2000 and the national Red-lists as either critically endangered or endangered species, and (iv) currently spreading non-native species. Location data are published with all details in Tab. 1. Samples used for molecular 
analyses are listed in Tab. 2, along with the corresponding GenBank accession numbers.

\section{Comments on individual species \\ Aegopinella nitidula (Draparnaud, 1805)}

This species reaches its south-eastern limit of distribution in northern and northwestern Bohemia and northern Moravia (Horsák et al. 2013). It lives in humid to waterlogged habitats in river floodplains, less often also in wet forests in foothills. Its occurrence was unexpectedly confirmed in the otherwise predominantly dry area of the České středohoří Mts in a riparian vegetation of the Žejdlík Brook.

Anisus septemgyratus (Rossmässler, 1835)

It is a rare and endangered species in many European countries, inhabiting small stagnant (often temporary) water bodies. In the Czech Republic, it is known only from southeastern Moravia near the confluence of the Dyje and Morava Rivers. Two new sites were found in this area in 2017 and 2019. In June and September 2019, four new localities of this rare species were discovered in eastern Slovakia near the villages of Beša, Kapušianske Kračany, Petrikovce, and Senné.

Arion intermedius Normand, 1852

This is the smallest slug species of the Czech Republic (body length up to $25 \mathrm{~mm}$ ), living in litter of mixed and coniferous forests. The main area of its distribution is in Western Europe while in the Czech Republic it is known to be common only in the Jizerské hory Mts and Ostrava region. There are some isolated findings from other mountain ranges in Bohemia such as the northern Šumava Mts (HLaváČ \& Horsák 2000) and newly also the Lužické hory Mts in 2015-2016. It was also recorded from a lowland site by the Elbe River near the town of Kolín. The latest findings are from the littoral vegetation of the Hlubošský Pond in the Běstvina village in eastern Bohemia and from two alluvial forests in the České středohoří Mts.

\section{Arion obesoductus P. L. Reischütz, 1973}

This slug has been only recently discerned from another similar species of the genus Arion (A. fuscus). Until now, it was mostly known from hilly and mountainous areas of the Czech Republic. Two recent findings in central Bohemia come from deciduous non-synanthropic forests and thus suggest more extensive occurrence of the species in suitable habitats throughout the whole country.

\section{Aplexa hypnorum (Linnaeus, 1758)}

Less common and vulnerable species that inhabits stagnant and temporary pools and wetlands. The finding of this species in the Velká Fatra National Park is outside its known distribution range in Slovakia.

\section{Balea perversa (Linnaeus, 1758)}

The species typically lives on scree slopes and rocks, having abundant and frequent occurrences on limestones of the Pavlovské vrchy Hills in southern Moravia and in open scree slopes of the České středohoří Mts in north- western Bohemia. However, the majority of our populations lives on walls of castle ruins throughout the Czech Republic and in western and central Slovakia. New findings in 2018-2019 document its rare occurrence in a montane sycamore-beech forest in southern Bohemia. Its distribution in a natural habitat at this site is peculiar, because this species was repeatedly found only on the same single old sycamore maple tree. The same situation was documented also by HLAvÁč (2010) in German part of the Šumava National Park (Bavarian Forest National Park).

\section{Chondrula tridens (O. F. Müller, 1774)}

This species is associated with warm steppe sites on deep soils. Its occurrence is scattered in warm lowlands throughout the Czech and Slovak Republics. In the last decades, however, it has been declining sharply due to changes in landscape management. Nowadays, it occurs more in secondary habitats - road embankments, sunny mown lawns, etc. Its new findings (2015) from two localities in the foothills of the Doupovské hory Mts in western Bohemia are probably the westernmost documented occurrence in Bohemia outside the main area of its distribution.

\section{Clausilia rugosa (Draparnaud, 1801)}

This species, associated with damp limestone and argillite rocks, is often abundant in tufts of plants growing on the rocks. It is common and continuously distributed only on argillite rock faces in eastern Bohemia, the Moravian Karst and western Slovakia, with scattered occurrence in the western half of Bohemia (Horsák et al. 2013). The new locality in the town of Horažd'ovice (Sušickohoražd'ovické limestones) represents the only one from the crystalline limestone areas in the Šumava Mts and Šumava foothills from northwest to southeast.

\section{Cochlicopa nitens (Gallenstein, 1852)}

The species is highly hygrophilous and found in undisturbed, mostly relic wetlands in lowlands. Stable and abundant populations are documented in the Kokorrínsko - Máchův kraj Protected Landscape Area (PLA) in Bohemia (BERAN 2006a), scattered and isolated populations are evidenced throughout the lowlands in the Czech and Slovak Republics (Horsák et al. 2013). A completely isolated new locality (2016) comes from the Sumava foothills in the area of phygeographical subdistrict Strakonické limestones near the Domanice village. This wetland meadow is the only recent one with the occurrence of $C$. nitens documented in southwestern Bohemia, while an older site from 2010 near the village of Žichovice in the area of Sušicko-horažd'ovické limestones must be revised.

\section{Corbicula fluminea (O. F. Müller, 1774)}

The gradual spread of this non-native bivalve has been monitored in detail especially in the Czech Republic since its first finding in 1999 (BERAN 2000). New findings made in the years 2015-2019 document its further spread especially in the Vltava and Ohre Rivers. In the case of the Vltava River it was already found in Prague and also in the lower section of the Berounka River, while it has not yet been proven in the Sázava River (BERAN 2020b). 
The database of the Nature Conservation Agency of the Czech Republic (NDOP) also contains data from 2018 on the occurrence in the Slapy dam reservoir. In addition to running water this species was recorded in the Elbe River lowland in sandpits. It was also found in Moravia in the Morava River (the tributary of the Danube River) in 2018 (KomzÁK et al. 2018). According to the newest data, its spread continues as it was recorded in the Morava River upstream of its first records in 2019, as well as in the Dyje River downstream of Břeclav. Due to its occurrence in the Polish part of the Odra River (e.g. Cebulska \& KRODKIEWSKA 2019) it is possible to expect its spread to the Odra River and its tributaries situated in the Czech Republic.

In Slovakia, C. Aluminea currently occurs essentially in the entire flowing section of the Danube River, especially from the Austrian-Slovak border to Bratislava - Cunovo District and from the village of Sap to Štúrovo, thus avoiding the original Danube riverbed in the so-called derivation area of the Gabčíkovo waterworks. Corbicula fluminea also penetrates into the Lesser Danube (the large sinistral branch of the main Danube River), the lower sections of the Danube tributaries (Morava, Váh, Hron and Ipel' Rivers), several sites are also known from the drainage ditches network in the Danubian Plain (ČEJKA 2019b). Due to its biology, C. fluminea is spreading very rapidly, creating mass populations, especially in the Danube (about 10,000 individuals per square meter).

Cornu aspersum (O. F. Müller, 1774)

Originally a Mediterranean species, currently it occurs along the west coast of Europe from Portugal to southern Sweden (voN Proschwitz 1997) and Great Britain. This species is relatively common in several European cities, e.g. in Vienna (DUDA \& MrKvicka 2014) or Budapest (PÁLl-Gergely et al. 2019). The first population in the Czech Republic was found in Prague, Holešovice in 2008 (JUŘIČKOVÁ \& KAPOUNEK 2009); as of 2020 the population thrives. In Slovakia, it was first recorded in the horticulture centre of the village of Vígl'aš in 2015 (Zvolenská kotlina geographical unit; ČEJKA 2015a), other records come from 2015-2018 from Bratislava (ČEJKA 2015a). The species is synanthropic and is probably introduced quite often: in Prague it was found in Hanspaulka in 2017 (D. Ríhová, pers. comm.), shells were uncovered near Viničná Street in 2018 (living population confirmed in July 2020) and in Veleslavín in 2020 (DolEžAL 2020). A live C. aspersum was found in a garden centre in Buštěhrad in 2013, several individuals near Mělník in 2016; a single shell near a parking lot in Brno in 2015, and a live individual in Stará Boleslav in 2020.

Deroceras invadens Reise, Hutchinson, Schunack \& Schlitt, 2011

It is a non-native species in the Czech and Slovak Republics, previously known as Deroceras panormitanum (Lessona et Pollonera, 1882). In the Slovak Republic reliably identified for the first time in 2003 from a greenhouse of the Bratislava Botanical garden (DvořÁK et al. 2003). The first outdoor occurrences were recorded in 2017 in a horticulture centre in Bratislava, and more recent record came from the Stupava town, SW Slovakia, in 2018. First findings of $D$. invadens from the Czech Republic were reported from a natural habitat in northern Moravia already in 1996 (HoRsÁK \& DvoŘÁK 2003). The second outdoor finding came from southern Moravia near the town of Zlín (VAŠÁT 2019).

\section{Deroceras juranum Wüthrich, 1993}

At the end of the 19th century, this slug was considered endemic to the Jura Mts in Switzerland. It was later included in the species complex of $D$. rodnae s. lat., but the research by Hutchinson \& ReISE (2009) proved, on the basis of their anatomy and mating behaviour, that there are at least two separate species $-D$. juranum and D. rodnae s. str. Deroceras juranum currently occurs in the Czech Republic in two separate populations in the Lužické hory Mts in northern Bohemia and, more abundantly, in the Šumava National Park and Protected Landscape Area in southern Bohemia (VAŠÁT 2019). Its occurrence is most commonly associated with humid floodplain forests and open riparian vegetation along brooks and rivers, but it occurs also in natural deciduous forests. This species is not yet known from Slovakia. The related species $D$. rodnae s. str. occurs east of the Elbe River and inhabits primarily the Carpathian part of the Czech Republic.

\section{Dreissena bugensis Andrusov, 1897}

It is a non-native species in Slovakia, originating from the mouths of the Southern Bug and Dnieper Rivers. It has been a slower invader than $D$. polymorpha until recently (for details on ecology, distribution and spreading see vAN DER VELTE et al. 2010). As part of an occasional survey of the malacofauna of the Gabčíkovo Reservoir near the village of Hamuliakovo, 126 young individuals of this species were found in a littoral zone of the Gabčíkovo Reservoir in 2013 (ČEJKA 2016). A year later in September 2014, several empty shells were found at the Danube riverbank near the village of Zlatná na Ostrove during the malacological survey (ČEJKA et al. 2015).

\section{Euomphalia strigella (Draparnaud, 1801)}

This species has a strong affinity to dry habitats of forest-steppe or shrubs, rocky steppes and other open habitats. In suitable places, it is common throughout the Czech and Slovak Republics, abundant in central Bohemia and southern Moravia, and rather rare in eastern and southern Bohemia and northern Moravia (Horsák et al. 2013). The occurrence of the species near the village of Brloh in the area of the Strakonice limestones (2015) is, after a long time, the first verified record in the area of the Sumava foothills. In historical times, several occurrences in southern Bohemia have been reported (ULIČNÝ 1892-95), however, none of them has been verified so far. The situation is improving towards central Bohemia, where, however, a number of sites are of older date and the species has declined significantly in the last two decades (HoráčKové et al. 2014). 
Ferrissia californica (Rowell, 1863)

Non-native gastropod inhabiting slowly flowing and stagnant waters. It is often found also in isolated artificial water bodies such as sandpits and quarries. New records from northwestern Bohemia (BERAN 2019a) and eastern Slovakia (BERAN 2020a) are outside of its known range.

Gyraulus acronicus (J. B. Férussac, 1807)

Rare gastropod with a scattered distribution in the Czech and Slovak Republics. Several new sites were found in the area of its known occurrence in the Sázava River basin (BERAN 2020b) and in the southwestern Bohemia near the town of Sušice.

\section{Gyraulus parvus (Say, 1817)}

It is a non-native species of the North American origin. It is a widespread species in the Czech Republic while its occurrence in Slovakia has not been confirmed yet. Gyraulus parvus is very similar to Gyraulus laevis (Alder, 1838), and the differences between them are subtle. Several specimens probably belonging to G. parvus were found in the Orava Reservoir in northern Slovakia and abundant populations in the Zemplínská Šírava Reservoir in the eastern part of Slovakia (BERAN 2020a). Due to the fact that the taxonomic status of this species is uncertain, material has been collected for future genetic analysis.

Gyraulus rossmaessleri (Auerswald, 1851)

Rare gastropod inhabiting temporary pools and wetlands with the scattered distribution in the Czech Republic and southwestern part of Slovakia. Several new sites were found in the area of its known occurrence in northwestern Bohemia, Silesia and central Moravia. An isolated population was found in the Chřiby Mts.

\section{Helix lucorum Linnaeus, 1758}

Non-native species for the Czech and Slovak Republics. Helix lucorum is one of the two most widely distributed species of the genus, with a large range extending from Iran in the east to France in the west, including areas where it has been introduced (KoRÁBEK et al. 2018). In the Czech Republic, this species was first recorded in Prague in 2009 (Žižkov; Peltanová et al. 2012); the latest finding comes again from Prague, from 2020 (a garden in Dejvice district). In the Slovak Republic, an abundant population of H. lucorum was found for the first time in 2013 in Bratislava (see ČEJKA \& ČAČANÝ 2014 for details), two other sites were recorded from the town of Nitra in southwestern Slovakia in 2016 and 2020.

\section{Helix thessalica O. Boettger, 1886}

Formerly considered a synonym of Helix pomatia Linnaeus, 1758 , it was recently reintroduced as a valid species and reported also from the Czech and Slovak Republics (KorÁBEK, JuǨičKová et al. 2016b, KoráBEK et al. 2020). In the Czech Republic, the occurrences are limited to the valleys of the Jihlava and Oslava Rivers just above their confluence in the town of Ivančice. The distribution there was thoroughly revised in May 2020 (O. Korábek) and tissue samples were taken for a planned study, which should reveal the extent of hybridization with $H$. pomatia. On the right bank of the Jihlava River, $H$. thessalica lives in the Pekárka Nature Monument; this population appears to be restricted to a small area of about 2.4 ha, followed by an approximately $400 \mathrm{~m}$ wide hybrid zone with $H$. pomatia. On the left bank, $H$. thessalica was found between the Jihlava River and a mill race near Mohelno. It also occurs almost continuously between the Letkovice and Hrubšice Villages, in places apparently with some admixture of H. pomatia. At the nearby site Bouchal, there is no pure $H$. thessalica population and only individuals of presumably hybrid origin were found. By the Oslava River, a large population has been found in the village of Čučice, from the valley bottom to the upper village margin, and some individuals exhibiting features of $H$. thessalica have been found in the town of Oslavany, across the river from the chateau. Earlier findings based on a few empty shells from the towns of Moravské Bránice and Nové Bránice (KoRÁBeK, JuŘičKoví et al. 2016a) could not be confirmed. It seems that the authors had a tendency to identify empty shells as $H$. thessalica more likely than live snails; these two localities are apparently based on misidentified shells.

In Slovakia, $H$. thessalica is found locally within a broad area in the centre of the country. Findings verified by dissections include sites by Podbrezová, Tisovec, Muráň, Bakta and Hájnáčka settlements. Further records are based only on empty shells and should therefore be considered less trustworthy: the central valley of the Pol'ana Mts and the villages of Budča, Nemecká, Čierny Balog, Ohnište near Liptovský Hrádok, Dudince, and Nová Bašta near Hajnáčka. Also here some of the populations show signs of an admixture with $\mathrm{H}$. pomatia. This Slovakian range of $H$. thessalica extends also to northern Hungary, where the species is found in the Bükk Mts.

\section{Ladislavella occulta (Jackiewicz, 1959)}

This aquatic species has been always rare, in the past known only from a single site in the Czech Republic since 1942 (BERAN 2002). Later on, a new site was discovered in southernmost Moravia (BERAN 2008). These populations were both recently confirmed. In June 2019, this species was recorded in Slovakia for the first time. An abundant population was discovered near the village of Senné (wetland meadows and shrubs, small shallow pools and ditches).

Limacus flavus (Linnaeus, 1758) and Limacus maculatus (Kaleniczenko, 1851)

Limacus flavus has been reported for a long time only from indoor sites, mainly cellars and city underground, and considered a true synanthropic species (DvořÁK \& Horsák 2004). In the Czech Republic, it occurred in many indoor sites at the beginning of the 20th century. When hygienic measures were later applied, it became rare, e.g. the record in 2003 from Olomouc (DVOř́́K \& Horsák 2004) and from the village of Kardašova Řečice (2013 and 2015). It was always rare in Slovakia, with only two recent indoor records: the village of Cabaj-Č́por near Nitra Town and the village of Zavar near the Trnava Town, where the 


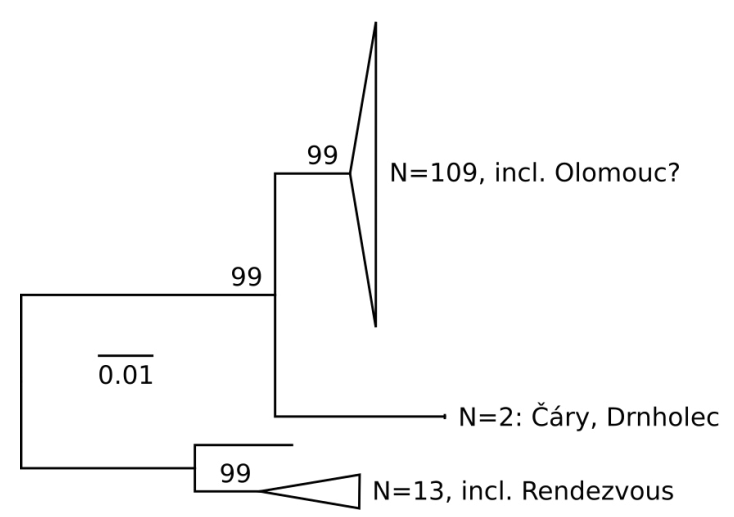

Fig. 1. Scheme of the phylogenetic relationships among coxl haplotypes of Limacus. A neighbor-joining tree is shown; the tree is unrooted because no taxon related closely enough to Limacus to be used to root the coxl phylogeny is known (Nitz et al. 2013). Number of samples in each clade and the placement of the four individuals analysed here is indicated for each group. The position of the sample from Olomouc is uncertain as we did not obtain a properly read sequence (see text for details).

slug was found in a 130-year-old grocery store building with a stone cellar. Indoor occurrences are certainly underestimated as the species is active at night and during rainy weather as observed at the latter site, where dozens of individuals climbed into the street through a ventilation opening of the cellar covered with stones. Over the last few years, Limacus has been reported also from several outdoor sites in the southernmost parts of the countries, with confirmed overwintering at several sites. The first outdoor record was made in southern Slovakia at a cemetery in the Čáry village (2003). Since 2015, a number of records were made in southernmost Moravia. Robert Vlk reported a colony of this slug from a cellar in the village of Drnholec in 2015 and in the same year he confirmed overwintering of the species in his garden. Between 2016 and 2019 , several outdoor records were made near the towns of Břeclav, Valtice, Hodonín and Lednice. Limacus slugs seem to be now common in the outdoors in this area.

The appearance of a population from the Rendezvous NNM near Valtice suggested that the slugs may actually belong to L. maculatus instead of $L$. flavus. This identification was corroborated by mitochondrial coxl DNA barcode. As a reference, we used the data from Rowson et al. (2014), who barcoded both L. flavus and L. maculatus in a study from the British Isles. The sample from Rendezvous NNM belongs to the clade identified as characteristic for L. maculatus by these authors and is identical to one of the sequences from their study. We also analysed three other samples, identified as L. flavus, from Čáry (ca. $25 \mathrm{~km} \mathrm{SE}$ from Rendezvous NNM), Drnholec (ca. $25 \mathrm{~km} \mathrm{NW}$ ), and Olomouc (ca. $100 \mathrm{~km} \mathrm{~N}$ ). These samples yielded identical sequences which grouped with a clade identified by Rowson et al. (2014) as typical for L. flavus, but were basal to all other sequences of this clade available from GenBank as of June 2020 (see Rowson et al. 2004, GómEZRoDRíGuEZ et al. 2019). The sample from the town of Olomouc yielded only poor quality fragments of the sequence, which did not allow for unambiguous phylogenet- ic placement; nevertheless, the results indicated that most probably it belongs to the lineage broadly distributed in western Europe (Fig. 1).

It has to be noted that Rowson et al. (2014) found the barcoding unreliable due to, probably extensive, hybridization upon contact between L. flavus and L. maculatus. Therefore, the results of the presented comparison are not per se conclusive with regards to the species identification. As with Monacha (see below), the problem here is that we lack detailed data from the native ranges of both species.

\section{Margaritifera margaritifera (Linnaeus, 1758)}

A critically endangered mussel species that is on decline everywhere across Europe. It has been broadly distributed in the southwest of Bohemia and in several other places (SIMON et al. 2015), but decades of decline culminated by its extinction or functional extinction at most of the remaining localities. Its last Czech populations survive in rivers of southern Bohemia: the most numerous one in the Blanice River and its tributaries, a scattered population in the Teplá Vltava River and a small one in the Malše River. Remnants of old populations survive also near Aš in western Bohemia. A few old individuals were found in the Otava River (which once had a very abundant population) in the town of Horažd'ovice in 2017 (ВöHм 2017) and four surviving individuals were confirmed in the Jankovský Brook in the Vysočina Highlands in 2018 (A. PavLíčKo, pers. comm.).

Across Europe, most of the remaining populations lack recruitment and their reproduction thus depends on (semi) artificial rearing of the young mussels. The reasons are low production of glochidia, lack of suitable host fish (brown trout, Atlantic salmon) and no or little survival of juveniles in the first years after metamorphosis. The causes of the problems are complex, but include changes in landscape use, water pollution, and erosion and the resulting siltation of the rivers. The latter cause is among the most significant issues, but is extremely difficult to fix. In the last years, climatic changes add to the problems.

In the last three decades, several projects have been carried out to save freshwater pearl mussels in the southern Bohemian rivers. Organic and, in part, chemical pollution of rivers has been improved, and many measures have been taken to prevent stream eutrophication and erosion. In the last decade, restoration of several tributaries of rivers with the mussel populations and many other management measures have been introduced, especially on the Teplá Vltava River. However, relatively little has been achieved where erosion is a major problem (as is the case of the Malše River or the Zlatý Brook, a tributary of the Blanice River) caused by an extensive network of drainage ditches in spruce plantations. Also restoration of food resources is a difficult task due to changes in land use after the World War II and straightened streams.

However, there were some positive discoveries in the last years. In the course of the AT/CZ Interreg project Malsemuschel (2017-2020), tens of young (still fast-growing with wedge-shaped shell margins) pearl mussels from natural recruitment were found in the upper Malše River, which is a unique case among the Czech localities of the 
species where there was no natural recruitment for decades. In the Teplá Vltava, young mussels from breeding were found and some other are believed to be a result of release of infested trouts. Another population of juvenile mussels (6-7 years) was found in 2019 in the Aš region in a stream where artificially infested trouts were kept.

There are ongoing projects to rejuvenate the populations by semi-natural breeding of juveniles and release of trouts infested by glochidia. These efforts are most advanced for the Vltava, Blanice and Malše; the breeding is about to start this year for the Zlatý potok. For the populations near Aš a rearing facility has been recently built in Bavaria. For the Zlatý Brook and Vltava populations, glochidia from the Blanice River (the same conservation unit; SIMON et al. 2015) are being used due to the difficulty to obtain glochidia in situ. The assisted reproduction thus bears a risk of causing a bottleneck effect and reducing the genetic diversity of the new generation. This is further illustrated by the situation in the Malše, where it was possible to obtain glochidia from just a few individuals (the target was six at each of two sampling sites, repeated for three years) and reduction in genetic variability among the juveniles was observed compared to the adult population. As a safety measure due to the risk of disturbance by visitors and even theft of the mussels, the precise locations of the freshwater pearl mussel occurrence are kept confidential by us as well as by nature conservation authorities.

\section{Massylaea vermiculata (O. F. Müller, 1774)}

This large land snail species is common in the Mediterranean area; its distribution ranges from eastern Spain to the Crimea (Israel, Egypt, eastern Spain, eastern Bulgaria, southern Greece). In the city of Bratislava, Slovakia, one living individual of this species was found in the horticultural facility, which is situated next to the Danube River arm on the south; the animal was found in the water supply shaft (ČEJKA 2019a) (Fig. 2). CAPINHA et al. (2014) claimed that $M$. vermiculata is able to establish viable populations only in areas where climatic conditions are similar to or warmer and wetter than those of the native range.
Later, Mienis $(2015,2017)$ as well as Ronsmans \& VAN DEN NEUCKER (2016) reported on successful overwintering of introduced populations in Belgium and the Netherlands. This might be an indication that also Central European climatic conditions might be suitable for the overwintering of this species. In Budapest, a newly discovered specimen was found in the yard of a condominium, suggesting that it arrived either with garden plants as a stowaway, or as a souvenir from holidays in the Mediterranean. The fact that it was discovered in March suggests that it may have overwintered there (PÁLL-GERGELY et al. 2020). The occurrence in Slovakia needs to be monitored to find out if this was a single released individual (the species is commonly kept as a pet) or a viable population has been already established outdoors.

\section{Menetus dilatatus (Gould, 1841)}

This species is native to North America. It was first found in the Czech Republic in 1994 (BERAN 1994), but has not yet been found in Slovakia. In 2017 and 2019, this species was found in new sites in the Elbe Lowland and northwestern Bohemia.

\section{Monacha claustralis (Rossmässler, 1834)}

PIEŃKOWSKA et al. (2015) found that there are two species of Monacha in the Czech Republic. Besides M. cartusiana (O. F. Müller, 1774), which is spreading in the Czech Republic since 1990s (KoLOUCH 1996, 2005, LožEK 1999, Peltanoví et al. 2012), they reported its close relative M. claustralis Rossmässler, 1834, found among Monacha samples from Prague. The species are very similar and cannot be distinguished by shell, but $M$. claustralis differs from $M$. cartusiana by a longer vagina lacking a vaginal sac (a lateral bulge on the vagina, HAUSDORF $2000 \mathrm{a}, \mathrm{b})$. The two species are also represented by two distinct mitochondrial clades (PIEŃKOWSKA et al. 2015). So far, M. claustralis has been reported from a number of sites in Poland, from Jena in Germany, Prague, Bosnia and Herzegovina, and Georgia (NeIBER \& HAuSdorf 2017, PieńkOWSKa et al. 2018, HutCHINSON et al. 2019).
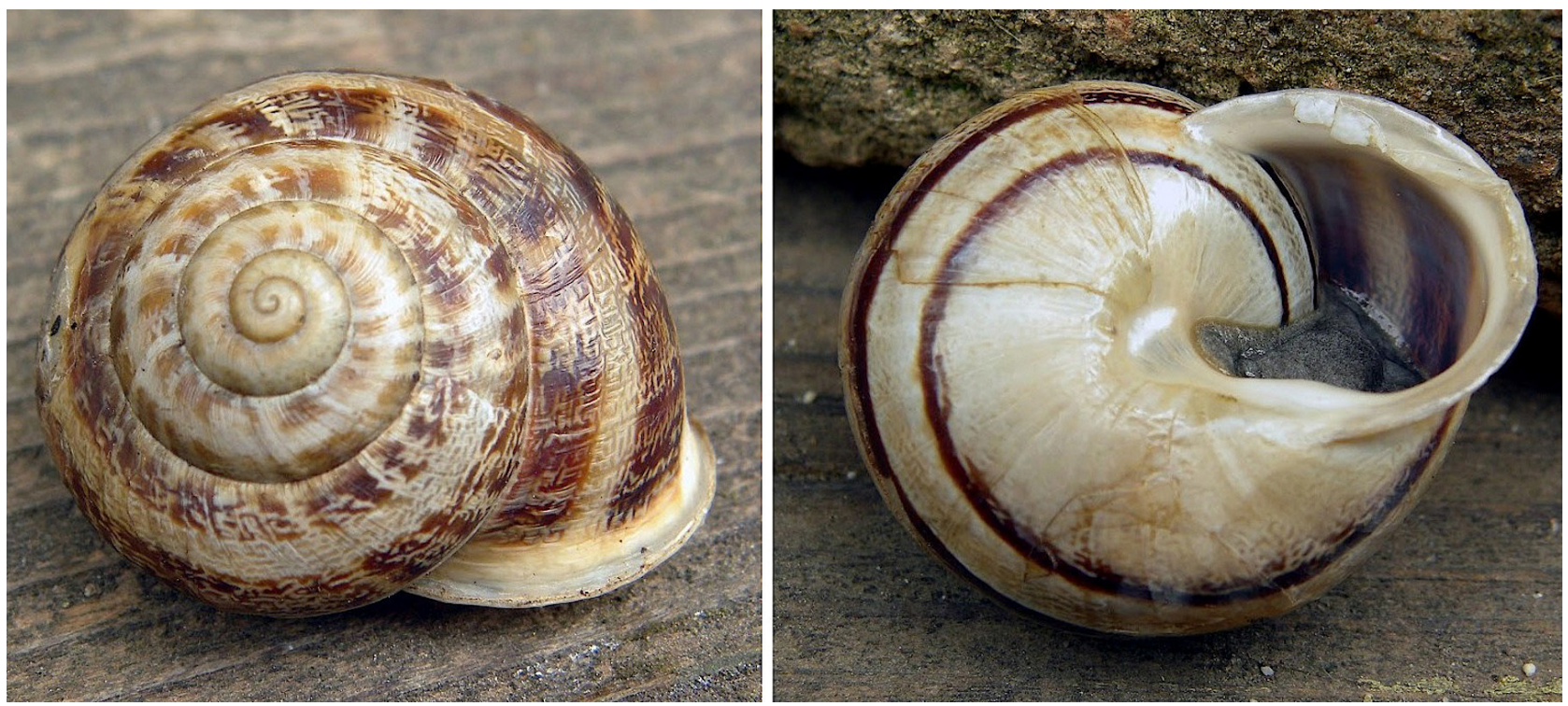

Fig. 2. Live individual of Massylaea vermiculata from the city of Bratislava, Slovakia. Foto ex PÁLL-GergELY et al. 2020. 


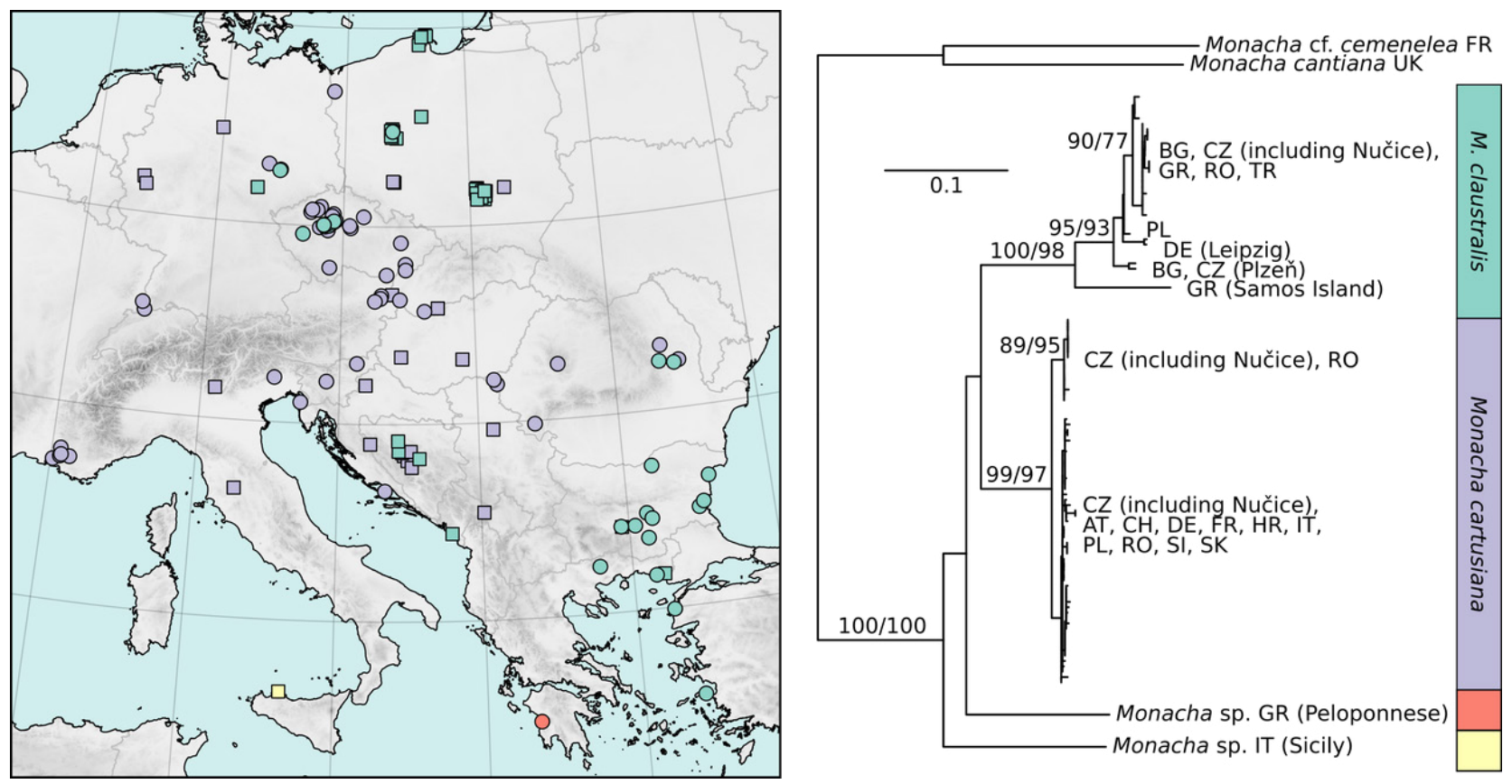

Fig. 3. Distribution of the mitochondrial lineages of the clade uniting Monacha cartusiana and M. claustralis based on published data from Manganelli et al. (2005), Pieńkowska et al. (2015, 2016, 2018), Neiber \& Hausdorf (2017) and Hutchinson et al. (2019) (squares) as well as our own data (circles). A phylogeny of the new samples (from a maximum likelihood analysis of a concatenated alignment of partial $16 \mathrm{~S} r R N A$ and coxl genes) is shown, labelled with two-letter country codes to indicate origin of the samples. The analysed samples and corresponding GenBank accession numbers are listed in Tab. 2. For a complete representation of relevant major lineages, a Sicilian sample from NeIBER \& HAUSDORF (2017) is included. Labels above branches show branch support values (SH-aLRT supports/bootstrap \%).

The core of its range lies in the southern and eastern Balkans (Albania, Macedonia, Greece, Bulgaria) and western Turkey (HAUSDORF 2000a, IRIKOV 2008, WELTER-SCHULTES 2012). Monacha cartusiana has generally a more westerly distribution extending from the Balkans to Spain (PIEŃKOwsKa et al. 2018), but, in the east, it is found up to the western Caucasus, where both species were probably introduced by humans (HAUSDORF 2000b).

In Fig. 3 we show the distribution of the mitochondrial clades corresponding to $M$. claustralis and M. cartusiana as recorded in an unfinished study of Monacha systematics (Míkovcová-Peltanová et al. unpublished data). The data complement those collected by PIEŃKOwSKA et al. (2018, Fig. 9). Besides three sites in Prague, M. claustralis haplotype was found in the villages of Choteč and Nučice west of Prague, and in the Plzeň Town. The phylogeny indicates that the population in Plzeň was introduced from a different source than the one in Prague. The alleged record of Monacha cantiana (Montagu, 1803) (HLAváČ \& Peltanoví 2010) from the premises of the National Museum in Horní Počernice, Prague, refers to M. claustralis (PIEŃKowska et al. 2015, here we present data from the original lot of Hlaváč \& Peltanová 2010).

The taxonomy of the $M$. cartusiana- $M$. claustralis pair may not be definitive. We disagree with PIEŃKOWSKA et al. (2015) that the "molecular affinity and the constancy of morphological characters of the M. claustralis specimens from widely distant sites also diminish the importance studying fresh topotypical materials". The type locality of M. claustralis is Corfu. As Fig. 3 shows, at the base of the clade uniting $M$. cartusiana and $M$. claustralis clades there are lineages found in Greece (Peloponnese, eastern Aegean) and Sicily. Species limits in this group thus can only be assessed taking populations from southernmost Europe into account, not only based on recently established populations from Central Europe. Sampling in the south would also uncover the original sources from where both species expanded.

The distinction between M. cartusiana and M. claustralis is not as clear-cut as presented by PIEŃKOWSKA et al. (2015, 2018). Specimens with M. claustralis haplotype but with a bulge on vagina from the Prokopské Valley in Prague, Choteč and Nučice led us to examine the population in Nučice more closely in 2015. We found the $M$. claustralis haplotype there also in individuals having a well-developed bulge on the vagina, not only in those with M. claustralis morphology. Haplotypes of M. cartusiana were also present. In addition, we examined some individuals from Romania. There, the bulge was developed as a triangular ridge and not as a distinct knob, but we found it present regardless whether the specimen possessed a M. cartusiana or M. claustralis haplotype. Monacha cartusiana and M. claustralis in Central Europe possibly represent lineages of the same species derived from different parts of its native range.

Pagodulina pagodula (Des Moulins, 1830)

It lives in leaf litter in shady woodlands, mainly on calcium-rich substrate. The main area of distribution is in the Alps, northern Italy and southern France (WELTER-SCHULTES 2012). Northwards from its continuous area of distribution, it was only known from two localities 


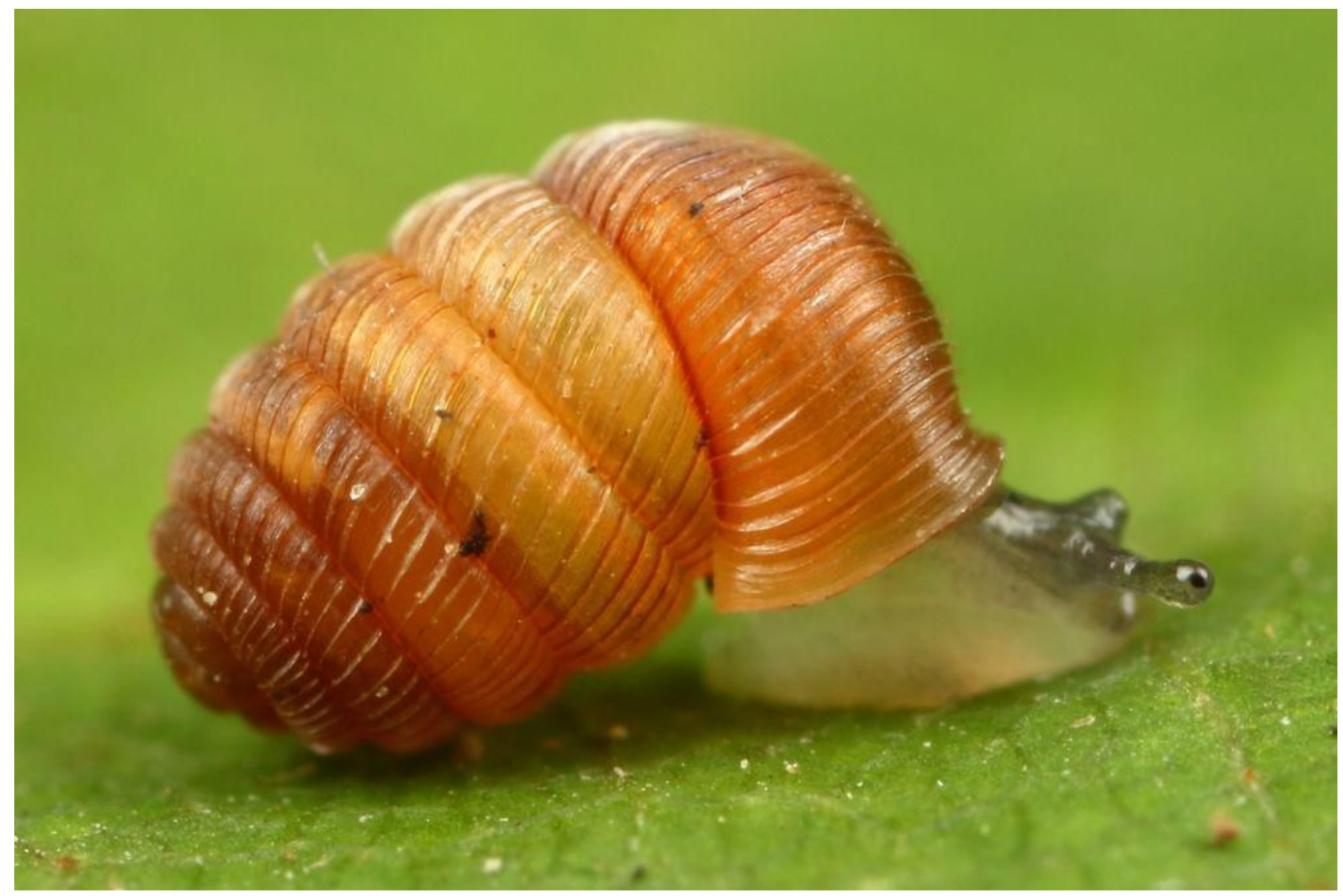

Fig. 4. Live individual of Pagodulina pagodula from the Podyjí National Park. Photo: R. Coufal.

in Slovakia and one in Poland (LISICKÝ 1986). In 2011, the species was found in the Mutenská obora NR near the town of Slavonice (LACINA \& HoRsáK 2012) followed by a discovery of another population in 2018. The latter population lives near Vranov nad Dyjí in a small valley of a nameless tributary of the Dyje (Thaya) in the Podyji National Park (Fig. 4), where it occurs in relatively high numbers within a small area. Based on these recent findings, northwards of its main area of distribution the species shows an affinity to undisturbed and humid deciduous forests. Fossil records of the species from the Czech and Slovak Republics indicate that throughout the Pleistocene, $P$. pagodula occupied much larger area than nowadays (LOŽEK 1986). From the Holocene deposits, the species is known only from the Mituchovci site in the Western Carpathians (Frodloví \& Horsák under revision) and from the Loucký spring in the Podyjí NP (ca. $8 \mathrm{~km}$ from the recent population; LOŽEK \& VAŠÁTKO 1997). Therefore, it appears that $P$. pagodula survived in the Podyjí NP only on this small patch, because it was not discovered there before, despite an extensive malacological survey (LOŽEK \& VAŠÁTKо 1997).

Pisidium amnicum (O. F. Müller, 1774)

Originally widespread pea mussel inhabiting lowland running waters. Due to pollution and straightening of most watercourses, it has currently become an endangered species occurring mostly in brooks or small rivers (BERAN et al. 2017). Between 2015-2019, this bivalve was confirmed at several known sites, e.g. brooks Klíčava, Liběchovka, Pšovka, Svitávka (BERAN 2018b), Žehrovka, and rivers
Ohře, Ploučnice (BERAN 2016b). Pisidium amnicum was also found in the Elbe River in 2013 and 2019, which are the first records from this river after more than 70 years.

\section{Pisidium globulare Clessin, 1873}

For a long time, the species has not been distinguished from the common generalist Pisidium casertanum (Poli, 1791). They differ in several shell features (HoRsÁk et al. 2013), but importantly also in autecology and habitats they occupy. Pisidium globulare is associated with shallow wetland waters from alluvial pools rich in submerged vegetation to sedge or even Sphagnum wetlands. About three dozens of sites have been recorded since the time the wetland populations of " $P$. casertanum" have been monitored as a separated species (Horsák \& Neumanová 2004). It occupies all large lowlands across the whole country, but some isolated populations in hilly landscapes were also found, as that newly reported one from the Chriby Mts (near the Stupava village). The conclusion that the species is not common is supported by the fact that only five new records have been conducted between 2015-2019; notice that three of them are very close to each other.

\section{Pisidium hibernicum Westerlund, 1894}

Originally reported only from standing waters, where it became virtually extinct during the last decades due to anthropogenic eutrophication and the intensification of fish production in ponds. During the last two decades, several new sites were discovered in preserved upper course of the rivers (hyporithral, grayling zone), mainly in SW Bohemia (VAŠÁTKO \& HoRSÁK 2000). Some new records were made 
in 2015 during a hydrobiological reference monitoring of the quality of running waters in the Czech Republic.

Pisidium moitessierianum Paladilhe, 1866

This rare pea mussel inhabits mostly slowly flowing waters with fine sediments. Several new sites were found in artificial canals of the Bečva River in Moravia and in the Elbe River in Bohemia.

Pisidium pseudosphaerium J. Favre, 1927

This critically endangered pea mussel inhabits mostly overgrown standing waters in the Czech Republic (BERAN 2016a). Some new sites were found between 2015-2019 in Bohemia, i.e. the western part of the Czech Republic.

\section{Pisidium tenuilineatum Stelfox, 1918}

A species with critically endangered status in the Czech Republic (BERAN et al. 2017) and Slovakia (ŠTEFFEK \& VAVROvá 2006). It inhabits mostly small watercourses with fine sediments. During 2015-2019, its occurrence was confirmed at some sites: the brooks of Pšovka and Liběchovka in the Kokořínsko - Máchův kraj PLA and in a small brook in the Poodři PLA. The latter site has been known from 1978 (MÁcHA 1982). One new site was found in Moravia in the artificial canal of the Bečva River and two new sites were found in Slovakia (BERAN \& ČEJKA 2019).

Planorbis carinatus O. F. Müller, 1774

This species is endangered in the Czech Republic (BERAN et al. 2017) and critically endangered in Slovakia (Š TEFFEK \& VAVROVÁ 2006). It is more common in the western part of the Czech Republic in basins of the Ohře and Berounka Rivers. Many new sites were found in 2015-2019. Some of them are outside of its known distribution range mentioned in Horsák, ČEJKA et al. (2020). In 2019, it was found in small and nutrient poor brooks Rokytnice and Lužní potok (boundary between the Czech Republic and Germany), together e.g. with Margaritifera margaritifera.

\section{Potamopyrgus antipodarum (Gray, 1843)}

This gastropod is native to New Zealand. Its occurrence in the Czech Republic has been known since 1981 (KUCHǍ 1983) and currently it inhabits extensive part of the Czech Republic (LoRENCOVÁ et al. 2015) and southwestern part of Slovakia (HoRsÁK, ČEJKA et al. 2020). Many new sites were discovered during 2015-2019; only the more notable records outside of its known range are shown in Table 1.

\section{Pseudanodonta complanata (Rossmässler, 1835)}

This mussel species is declining in most European countries and is listed in the IUCN Red List of Threatened Species as Vulnerable (VAN DAMme 2011). In the Czech Republic, it lives mostly in rivers (e.g. BERAN 2002, 2019b) but its occurrence is also known from dam reservoirs (HoRÁČKovÁ et al. 2014). In 2019, P. complanata was found in the Zemplínská Š́rava Reservoir in Slovakia (BERAN 2020a) and some noteworthy populations have been discovered in years 2015-2019 in the rivers of Sázava (BERAN 2020b), Chrudimka (BERAn 2016c), Radbuza, and Úhlava.

\section{Pupilla alpicola (Charpentier, 1837)}

It has always been a rare species in the Czech Republic, recently known only from a few calcareous fen meadows and low-sedge wetlands (HoRsÁK, ČEJKA et al. 2020, http://mollusca.sav.sk/malacology/maps/pupilla-alpicola. jpg). A new isolated population was found in northern Bohemia near the village of Stvolínky (BERAN 2017a).

\section{Pyramidula saxatilis (Hartmann, 1842)}

As a valid species recognized based on molecular phylogeny by RAZKIN et al. (2016), which also reported a single population from the Velká Fatra Mts in Slovakia. It is a common species in most of the Alps, mainly in higher elevations. Preliminary results suggest that it occurs only in a small area of the Velká Fatra Mts, in the vicinity of Horný Jelenec near Donovaly. The original record of J. Steffek (his sample was analysed by RAZKIN et al., 2016) was resampled in 2019 and confirmed by DNA data. Two other populations were found in close vicinity of the original site. Distribution in Slovakia and particularly in the Vel'ká Fatra Mts requires further investigation.

\section{Radix ampla (Hartmann, 1821)}

In Slovakia, it is known only from a few disjunct areas. Two new sites in the Turiec River were found in 2017 (BERAN \& ČEJKA 2019) and 2019.

\section{Sinanodonta woodiana (Lea, 1834)}

An invasive species that has been spreading rapidly in the last decades. It inhabits fishponds, dam reservoirs and rivers. At many places it becomes the dominant unionid. The occurrence of $S$. woodiana has been known from many sites, especially in southern Bohemia, southeastern and central Moravia and southern Slovakia. Plenty of new sites were found during 2015-2019. Notable records are from the Odra River in Silesia and from the Zemplínská Šírava Reservoir (BERAN 2020a).

\section{Sphaerium nucleus (Studer, 1820)}

A species recently distinguished from $S$. corneum, whose distribution is underexplored. It is probably more common, especially at suitable places in the lowlands as the findings during 2015-2019 suggest. New records came from Silesia (the Odra River basin), southeastern Moravia (the Morava River basin), Elbe Lowland, Kokořínsko - Máchův kraj PLA, and Český ráj PLA (the Elbe River basin).

\section{Sphaerium rivicola (Lamarck, 1818)}

The largest European orb mussel that inhabits slowly flowing larger rivers in lowlands. In the Czech and Slovak Republics, it is currently known in particular from the largest rivers (Elbe, Vltava, Morava, Danube). Some new records came from the Ohře (northwestern Bohemia) and Sázava (central Bohemia; BERAN 2020b) Rivers.

Stagnicola turricula (Held, 1836) and Stagnicola palustris (O. F. Müller, 1774)

Some authors (e.g. BARGUES et al. 2001, 2005) do not consider $S$. turricula to be a separate species and do not distinguish it from S. palustris while the others (e.g. PIEŃKows- 
KA et al. 2015, PIECHOCKI \& WAWRZYNIAK-WYDROWSKA 2016) consider them distinct. Due to clear anatomical differences both taxa are currently distinguished in the Czech and Slovak Republics (HorsáK, ČEJKA et al. 2020). Stagnicola turricula is a common and widespread species in both countries (e.g. BERAN 2002, 2008, HoRsÁK, ČEJKA et al. 2020) while $S$. palustris has been known only from the Elbe Lowland and Prague. The occurrence of $S$. palustris in Prague Zoo was confirmed in 2019 (BERAN 2020c). In 2018, S. turricula was found in the Oudoleňský Brook, which is the first record in the Bohemian-Moravian Highlands (BERAN 2020b).

\section{Subulina striatella (Rang, 1831)}

A tropical species indigenous to Western Africa, widely introduced to many countries, e.g. to the Mascarenes. This species has usually been introduced with plants to greenhouses outside the tropical zone. In January 2019, employees of the Bratislava Botanical Garden, J. Capka \& $\mathrm{N}$. Zlámal collected three living individuals of this species from the plant leaves (Anchomanes difformis) imported from Central Africa (Mt. Cameroon, 2011). The identification was confirmed by M. Horsák (HorsÁk, NAGGs et al. 2020).

Tandonia kusceri (Wagner, 1931)

It is a non-native species to Slovakia, first recorded in Bratislava in the autumn of 2014 (KORÁBEK, ČEJKA et al. 2016). Its native range lies in southeastern Europe, isolated occurrences are known from Moldova, Ukraine (Gural-Sverlova et al. 2019) and the United States. Recently, it has been found to be distributed across Hungary (TuRócI et al. 2020). After the first finding in Bratislava, other six relatively distant localities were confirmed. Thus, this species has probably been already well established in the Bratislava region. The findings of T. kusceri in Slovakia come mainly from open and semi-open cultural landscape (e.g. small degraded alluvial forests, or shrubby habitats). Tandonia kusceri hides mainly under stones or pieces of concrete, less frequently under rotting wood or wooden boards; more likely it is to be found on a calcareous substrate. It is possible that most of the findings of T. rustica reported by DvořÁK \& ČEJKA (2004) from Bratislava and the surrounding area actually belonged to $T$. kusceri. This would mean that $T$. kusceri lived in the city at least 10-15 years before the "first" record in the Bratislava Ružinov district. Unfortunately, the authors were convinced that it could not be other species than T. rustica, so they did not make photo documentation, nor did they dissect the individuals for an accurate identification. In the past, this species was reported from Bratislava by PonEC (1967, 1972) from the vineyards of the Rača district (Fig. 5), FLASAR \& Kroupoví (1976) listed T. rustica from the Bratislava Botanical Garden and ŠTEFFEK (1978) from the southernmost part of the Malé Karpaty Mts (Bratislava Forest Park, 48.1900N, 17.0823E) and from the Bratislava Nové Mesto district (48.1780N, 17.1425E). Seven hundred meters as the crow flies from the last named locality, a rich population of T. kusceri was found in 2018. The isolated record comes from the town of Banská Štiavnica. As this is the area of the field research centre of the Slovak Academy of Sciences in Bratislava, it is probable that this species was introduced there, e.g. with building material. However, TURócI et al. (2020) confirmed by dissection a record of $T$. rustica from Györ, which suggests these eastern records of the species may well be correct.

\section{Truncatellina costulata (Nilsson, 1823)}

This species is very rare in the Czech and Slovak Republics, known only from the Pavlovské vrchy Hills in southern Moravia (HoRsÁK 2000, NovÁK \& NovÁK 2013), recently found near the village of Trusnov in eastern Bohemia (MYš́́K 2011), and from several limestone hills in the Malé Karpaty Mts in Slovakia (Horsák et al. 2013). The last known site was found in the ruins of the Trosky castle in the Český ráj PLA (2013) (Fig. 6). The Trosky population is quite rich and lives only on grassy basalt rocks and their foot under the Baba tower (40 live specimens in the

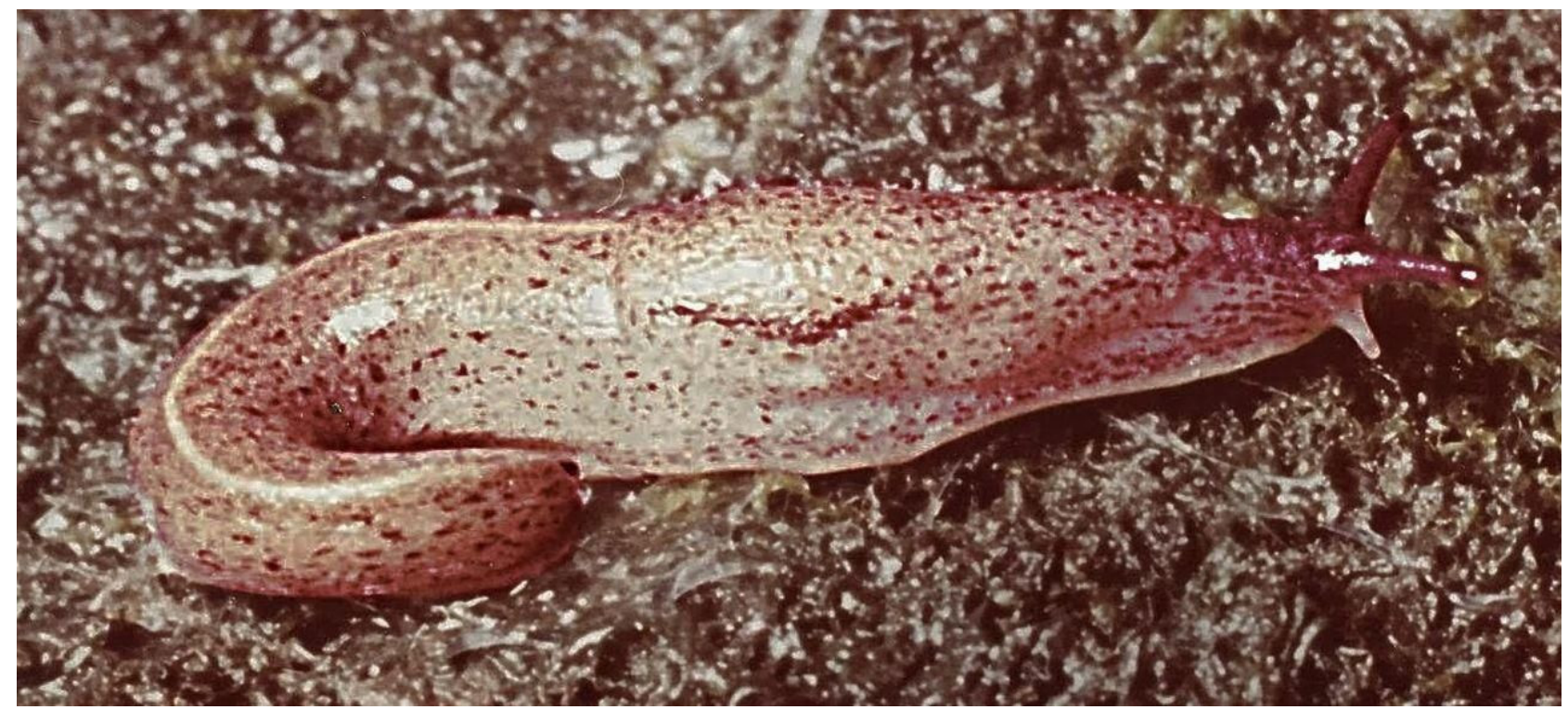

Fig. 5. The photograph which was published by PONEC (1967) in his diploma thesis. The spotted pattern suggests that it could indeed be Tandonia rustica. The individual comes from the vineyards of Bratislava - Rača City district. 


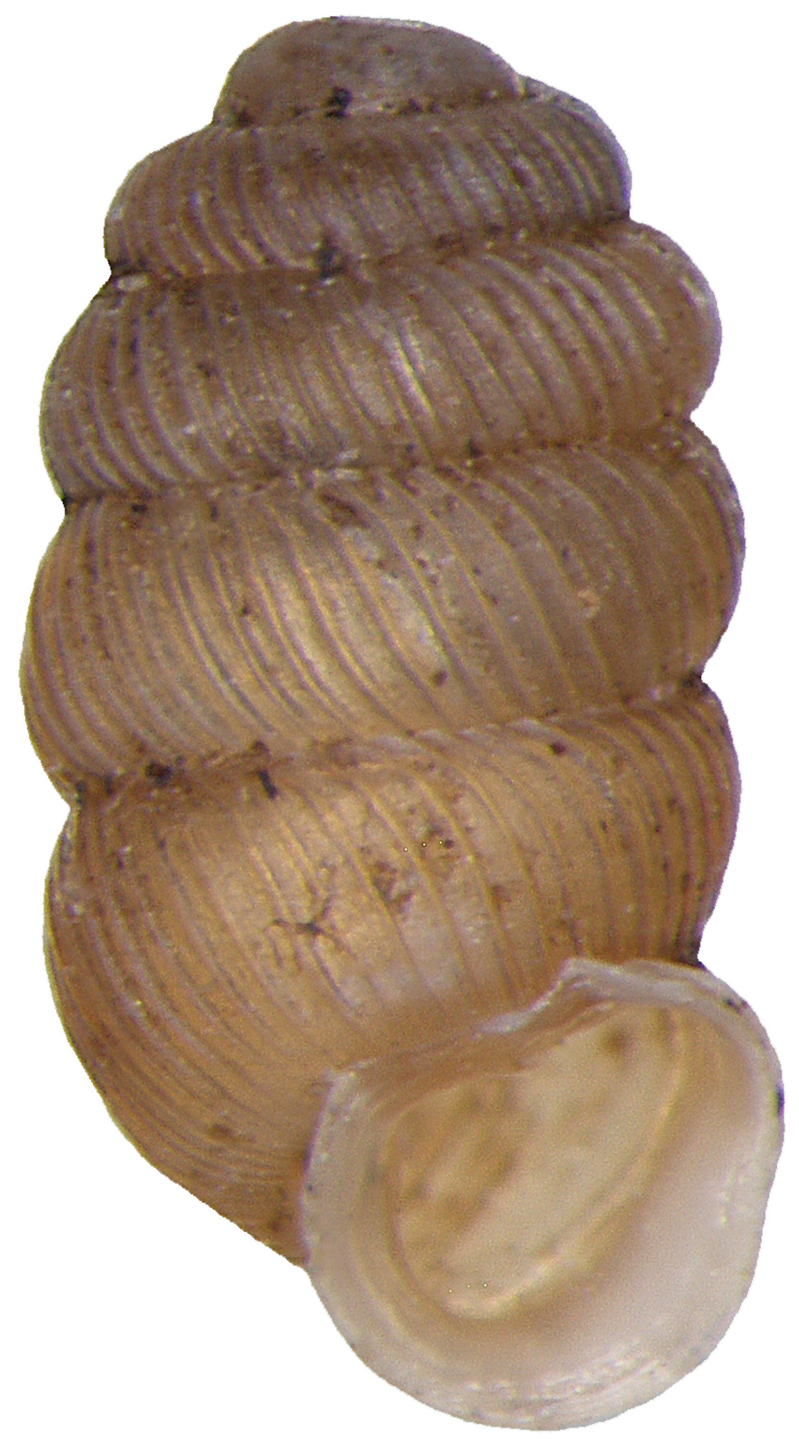

Fig. 6. The shell of the snail Truncatellina costulata from the Trosky castle ruins (northern Czechia). Photo: M. Horsák.

2 liters of soil/litter sample), while other suitable sites in the Trosky castle are inhabited only by $T$. cylindrica.

Unio crassus Philipsson, 1788

This unionid is considered endangered in the Czech Republic (BERAN et al. 2017) and is also listed in the IUCN Red List of Threatened Species as threatened (Lopes-LIma, Kebapçi \& Van Damme, 2014). By the end of the 20th century the volume of information had gradually increased and attention was paid mainly to the search for its more numerous populations. This survey was intensified at the beginning of the 21 st century in connection with the preparation of the Czech Republic's accession to the European Union and the need for establishment of NATURA 2000 network and Sites of Community Importance (SCI) with populations of this bivalve. Nearly all of the previously known sites in the Czech Republic became SCI (or part of SCI) and populations of this species are monitored. In years 2015-2019 some new populations were found in the Czech Republic especially in smaller rivers, e. g. Chrudimka and Novohradka in eastern Bohemia (BERAN 2016c, 2018a), Klejnárka in central Bohemia,
Oslava in southern Moravia (BERAN 2019c), Sázava and some of its tributaries (BERAN 2020b), Moravice, Bečva, and Úhlava. Surprisingly, in 2019 this species was found also in the Elbe River. This is the first finding in this river after more than 70 years. In the Czech Republic, U. crassus currently inhabits mostly smaller watercourses (BERAN 2019b) while in Slovakia it still lives also in the largest rivers such as the Danube or Morava. A new population of this species in Slovakia was found in the Turiec River (BERAN \& ČEJKA 2019).

\section{Vallonia enniensis Gredler, 1856}

This is a very rare species in both countries (HoRsÁK, ČEJKA et al. 2020, http://mollusca.sav.sk/malacology/ maps/vallonia-enniensis.jpg), with only a few modern populations, inhabiting mostly treeless calcareous fens. A new isolated population from southern Moravia was found in the Jezero NM - a fen meadow near the village of Vacenovice.

\section{Vertigo angustior Jeffreys, 1830}

Although internationally protected, this species is still common, chiefly in Slovakia (HoRSÁK, ČEJKA et al. 2020, http://mollusca.sav.sk/malacology/maps/vertigo-angustior. jpg) inhabiting mainly open alkaline wetlands. New and isolated populations were discovered in the Slavkovský les PLA near the village of Poutnov (Horsákoví \& Horsák 2018) and in the southernmost part of the Bohemian-Moravian Highlands near the town of Slavonice.

\section{Vertigo geyeri Lindholm, 1925}

Over the last decade, ca. 30 new sites have been discovered in the Czech Republic (Horsáková \& Horsák 2018, HorsÁK, ČEJKA et al. 2020, http://mollusca.sav.sk/malacology/maps/vertigo-geyeri.jpg), where it was originally known only from a single site in the Český ráj PLA. Most of the new sites are in two areas of the Bohemian-Moravian Highlands. Several isolated sites were found also in western Bohemia, namely in the Šumava foothills near Sušice (Albrechtice, NNM Pastviště u Fínů, 2013) and Soběšice (Ve Volešku, Novosedelský Brook, 2014) on the wetland meadows, and in the Slavkovský les PLA near the village of Poutnov (HorsáKová \& Horsák 2018). In some areas of northern Slovakia it is still common in preserved alkaline and neutral fens, with ca. 60 stable populations sampled over the last 20 years (VAVRoví et al. 2009, SCHENKOvá et al. 2012).

\section{Vertigo lilljeborgi (Westerlund, 1871)}

This species was for the first time discovered in the Czech Republic by J. Hlaváč in 2012 (Horsák et al. 2017). Since then, other nine sites were found (see Horsák et al. 2017 for a full list of sites), located mainly in the southern part of the Bohemian-Moravian Highlands and in the southeastern part of the Šumava NP (HoRsÁK, ČEJKA et al. 2020, http://mollusca.sav.sk/malacology/maps/vertigo-lilljeborgi.jpg). Two recent records were found in the Krušné hory Mts in westernmost Bohemia, near Chomutov and Kraslice. 
Vertigo moulinsiana (Dupuy, 1849)

A rare species in both countries. In the Czech Republic, a continuous occurrence is known from the Kokořínsko - Máchův kraj PLA (BERAN 2006a, 2006b, 2007, 2017a), with several isolated populations scattered in lowlands of the country (HoRsÁK, ČEJKA et al. 2020, http://mollusca. sav.sk/malacology/maps/vertigo-moulinsiana.jpg). Four nearby populations are known in the vicinity of Loučen in central Bohemia (populations resampled in 2015 and 2016). An isolated site is known from the U Houkvice NR (population resampled in 2018). Two viable and classic populations are known from the Znojmo region in southern Moravia and from eastern Moravia very close to the border with Slovakia, where several, but isolated populations are recently known from calcareous treeless fens (VAVRová et al. 2009). Two new isolated sites have been discovered during the Malakodny field workshop in 2018 in the southern part of the Ždánický les region. The most recent new populations from Slovakia were found in the Zrubárka NR (ČEJKA 2018b) and in the Abrod NNR (ČAČANÝ 2020).

Viviparus acerosus Bourquignat, 1862

In the Czech and Slovak Republics, this species is native to the Danube River basin and inhabits slow-flowing rivers and canals in lowlands. It has been found outside its native range in the Czech Republic in years 2015-2019 at five sites (BERAN et al. 2019).

\section{Zebrina detrita (O. F. Müller, 1774)}

A new finding of the species on the rocky steppe in the Prokopské údolí NR in Prague was made in 2019 (leg. M. Šafka), as an accidental finding of empty shells. In 2020, re-collecting was carried out and a strong population was documented together with the accompanying malacofauna. Overall, the species is very rare in Bohemia and Moravia, and has been evidenced from the vicinity of Slaný (near Znojmo) and from the Moravian Karst. Another isolated population, secondarily introduced, comes from the Czech Karst near the village of Srbsko (HoRsÁk et al. 2013, PoDrouŽKová et al. 2020). The newly discovered site in Prague is most likely an aerial dispersion.

\section{Acknowledgements}

T. Čejka thanks Eike Neubert (Natural History Museum of the Burgergemeinde Bern, Switzerland) for confirming the identification of Massylaea vermiculata.

This work was partially supported by the Slovak Grant Agency VEGA (No. 2/0079/18), by the Podyjí NP Administration, and Research Plan of the National Museum Prague (No. DKRVO 2019-2023/6.II.b, 00023272).

Research of species distribution of freshwater pearl mussel populations was supported by two projects: AT/CZ Interreg project Malsemuschel (2017-2020) for the Malše River and OPŽP project Strengthening and protection of the freshwater pearl mussel population in the Sumava National Park (2014-2020) for the Vltava River.

We would like to thank the following collectors for the data provided (in alphabetical order): K. Beran, J. Beran,
V. Beranová, J. Bojková, Š. Buchta, J. Čapka, J. Černecký, K. Čulík, L. Dvořák, D. Fischer, J. Hlava, B. Holienková, V. Hrdlička, M. Chytrý, V. Janský, V. John, L. Jurek, L. Juřičková, P. Krásenský, V. Melichar, T. Němec, D. Němejcová, P. Pařil, O. Simon, M. Straka, M. Šafka, M. Vašát, R. Vlk, O. Volf, A. Vránová, N. Zlámal.

\section{References}

Bargues M. D., Artigas P., Jackiewicz M., Pointier J. P. \& Mas-Coma S., 2005: Ribosomal DNA ITS-1 sequence analysis of European Stagnicoline Lymnaeidae (Gastropoda). - Heldia, 6: 57-68.

Bargues M. D., Vigo M., Horak P., Dvorak J., Patzner R. A., Artigas P., Pointier J. P., Jackiewicz M., Meier-Brook C. \& Mas-Coma S., 2001: European Lymnaeidae (Mollusca: Gastropoda), intermediate hosts of trematodiases, based on nuclear ribosomal DNA ITS-2 sequences. - Infection, Genetics and Evolution 1:85-107. https://doi.org/10.1016/S15671348(01)00019-3

Beran L., 1994: Severoamerický okružák Menetus dilatatus (Gould) v České republice [The North American species Menetus dilatatus (Gould) in the Czech Republic (Mollusca: Gastropoda)]. - Práce muzea v Kolíně, řada přírodovědná, 1: 31-32. (in Czech).

Beran L., 2000: First record of Corbicula fluminea (Mollusca: Bivalvia) in the Czech Republic. - Acta Societatis Zoologicae Bohemiae, 64: 1-2.

BERAN L., 2002: Vodní měkkýši České republiky - rozšíření a jeho změny, stanoviště, šíření, ohrožení a ochrana, červený seznam [Aquatic molluscs of the Czech Republic - distribution and its changes, habitats, dispersal, threat and protection, Red List]. - Sborník přírodovědného klubu v Uh. Hradišti, Supplementum 10, 258 pp. (in Czech).

Beran L., 2006a: Měkkýši (Mollusca) CHKO Kokořínsko [Molluscs (Mollusca) of Kokořínsko Protected Landscape Area]. - In: Beran L. et al., 2006: Bezobratlí Kokořínska. [Invertebrates of Kokořínsko]. - Bohemia centralis, Praha, 27: 41-73. (in Czech).

Beran L., 2006b: New records of Vertigo moulinsiana (Gastropoda: Vertiginidae) and notes on its distribution and habitats in the Czech Republic. - Malacologica Bohemoslovaca, 5: 14-17. Beran L., 2007: Poselský rybník pond - a new site with occurrence of Vertigo moulinsiana (Gastropoda: Vertiginidae) in Northern Bohemia (Czech Republic). - Sborník Severočeského Muzea, Př́rodní Vědy, Liberec, 25: 37-38. (in Czech).

Beran L., 2008: A contribution to distribution of genus Stagnicola and Catascopia (Gastropoda: Lymnaeidae) in the Czech Republic. - Malacologica Bohemoslovaca, 7: 70-73.

BerAn L., 2016a: Pisidium pseudosphaerium Favre, 1927 (Bivalvia: Sphaeriidae) in the Czech Republic - rare or overlooked? - Folia Malacologica, 24: 57-62. http://dx.doi.org/10.12657/ folmal.024.005

Beran L., 2016b: Příspěvek k poznání vodních měkkýšů Ploučnice a její nivy mezi Českou Lípou a Mimoní [A contribution to the knowledge of aquatic molluscs of the Ploučnice River between the town of Česká Lípa and Mimoň]. - Malacologica Bohemoslovaca, 15: 21-29. (in Czech).

BERAN L., 2016c: Vodní měkkýši dolního toku Chrudimky - jediná lokalita Unio crassus v Pardubickém kraji? [Aquatic molluscs of the lower stretch of the Chrudimka River - the only site of Unio crassus in Pardubice Region?]. - Malacologica Bohemoslovaca, 15: 30-36. (in Czech).

Beran L., 2017a: Měkkýši Dolanského rybníka (severní Čechy) - př́íspěvek k poznání měkkýšů CHKO Kokořínsko - Máchův kraj [Molluscs of the Dolanský rybník Pond (Northern Bo- 
hemia) - a contribution to the knowledge of molluscs of the Kokořínsko - Máchův kraj PLA]. - Malacologica Bohemoslovaca, 16: 1-6. (in Czech).

BERAN L., 2017b: Vodní měkkýši Vysočiny [Aquatic molluscs of Vysočina Region (Czech Republic)]. - Malacologica Bohemoslovaca, 16: 44-76. (in Czech).

BERAN L., 2018a: Vodní měkkýši Novohradky [Aquatic molluscs of the Novohradka River]. - Malacologica Bohemoslovaca, 17: 8-12. (in Czech).

BERAN L., 2018b: Vodní měkkýši Svitávky v severních Čechách [Aquatic molluscs of the Svitávka River in Northern Bohemia]. - Malacologica Bohemoslovaca, 17: 13-16. (in Czech).

BERAN L., 2019a: Colonisation of the newly-created artificial lake Medard and its surroundings by aquatic molluscs. - Folia Malacologica, 27: 91-100. https://doi.org/10.12657/folmal.027.010

BERAN L., 2019b: Distribution and recent status of freshwater mussels of family Unionidae (Bivalvia) in the Czech Republic. - Knowledge and Management of Aquatic Ecosystems, 420, 45. https://doi.org/10.1051/kmae $/ 2019038$

Beran L., 2019c: Vodní měkkýši Oslavy [Aquatic molluscs of the Oslava River]. - Malacologica Bohemoslovaca, 18: 8-12. (in Czech).

Beran L., 2020a: Aquatic molluscs of the Zemplínska Šírava dam reservoir (East Slovakia) - Folia Malacologica, 28: 114120. https://doi.org/10.12657/folmal.028.006

BERAN L., 2020b: Vodní měkkýši Sázavy a vybraných př́itoků se zaměřením na ohrožené a nepůvodní druhy [Aquatic molluscs of the Sázava River and its selected tributaries with a focus on threatened and non-native species]. - Malacologica Bohemoslovaca, 19: 29-54. (in Czech).

BERAN L., 2020c: Vodní měkkýši Zoologické zahrady hl. m. Prahy [Aquatic molluscs of Prague Zoo]. - Malacologica Bohemoslovaca, 19: 55-60. (in Czech).

BerAn L. \& ČEJKA T., 2019: New records of Pisidium tenuilineatum Stelfox, 1918 (Bivalvia, Sphaeriidae) from Slovakia. Malacologica Bohemoslovaca, 18: 15-18.

Beran L., Horsák M. \& Hofman S., 2019: First records of Viviparus acerosus Bourguignat, 1862 (Gastropoda: Viviparidae) from the Czech Republic outside its native range. - Folia Malacologica, 27: 223-229. https://doi.org/10.12657/folmal.027.021

BERAN L., JuŘIČKová L. \& HorsÁK M., 2017: Mollusca (měkkýši). - In: Hejda R., Farkač J. \& Chobot K. (eds): Červený seznam ohrožených druhů České republiky. Bezobratlí. [Red list of threatened species in the Czech Republic. Invertebrates] - Př́roda, Praha, 36: 71-76. (in Czech).

BöHм M., 2017: Zpráva o výsledku průzkumu Mlýnského náhonu v Horažd’ovicích dne 26. 9. 2017 se zaměřením na vodní mlže k ověřní výskytu perlorodky říční [Report on the result of the Mlýnský náhon Mill-race in the village of Horažd'ovice on 26 September 2017 focusing on freshwater bivalves to verify the occurrence of freshwater pearl mussel]. - Final report, ms., Nature Conservation Agency, Prague, 153 pp. (in Czech).

Capinha C., Rödder D., Pereira H. M. \& Kappes H., 2014: Response of non-native European terrestrial gastropods to novel climates correlates with biogeographical and biological traits. Global Ecology and Biogeography 23: 857-866. https://doi org/10.1111/geb.12176

Cebulska K. D. \& Krodkiewska M., 2019: Further dispersion of the invasive alien species Corbicula fluminea (O. F. Müller, 1774) in the Oder River. - Knowledge and Management of Aquatic Ecosystems, 420, 14. https://doi.org/10.1051/ kmae/2019008

ČAČANÝ J., 2020: Prvý nález živej populácie ulitníka Vertigo moulinsiana (Dupuy, 1849) na Borskej nížine [The first record of a living population of the snail Vertigo moulinsiana (Dupuy, 1849) in the Borská nížina Lowland]. - Acta rerum naturalium
Musei Nationalis Slovaci, 65: 26-32. (in Slovak).

ČEJKA T., 2015a: Brown garden snail - Cornu aspersum (O. F. Müller, 1774) in Slovakia. - Malakologický bulletin/ Malacological Bulletin. Online at https://malbull.blogspot. com/2015/08/first-record-of-cornu-aspersum-o-f.html, accessed July 19, 2020.

ČEJKA T. 2015b: Three new mollusc species for Slovakia - result of one visit of the garden centre. - Malakologický bulletin/Malacological Bulletin. Online at https://malbull.blogspot. com/2015/08/four-new-mollusc-species-for-slovakia.html, accessed September 19, 2020.

ČEJKA T., 2016: Prvé nálezy nepôvodného lastúrnika (Dreissena rostriformis bugensis) v slovenskom úseku Dunaja [First records of the non-native bivlave (Dreissena rostriformis bugensis) in the Slovak stretch of the Danube River]. - Limnologický spravodajca, 10: 46-49. (in Slovak).

ČEJKA T., 2018a: First outdoor records of the slug Deroceras invadens from the Slovak Republic. - Malakologický bulletin/Malacological Bulletin. Online at https://malbull.blogspot. com/2018/02/first-outdoor-records-of-slug-deroceras.html, accessed September 19, 2020.

ČEJKA T., 2018b: Z červenej knihy slovenských mäkkýšov: pimprlík bruškatý (Vertigo moulinsiana) [From the Red Data Book of Slovakia: Desmoulin's whorl snail (Vertigo moulinsiana)]. - Malakologický bulletin/Malacological Bulletin. Online at https://malbull.blogspot.com/2017/06/z-cervenej-knihy-slovenskych-makkysov.html, accessed July 19, 2020. (in Slovak).

ČEJKA T., 2019a: Finding of the living individual of the land snail Massylaea vermiculata in the horticultural center (SW Slovakia). - Malakologický bulletin/Malacological Bulletin. Online at https://malbull.blogspot.com/2019/07/finding-of-living-individual-of-land.html, accessed July 19, 2020.

ČEJKA T., 2019b: Freshwater molluscan fauna in Danubian drainage ditches in Slovakia: high species richness and conservation value. - Acta Zoologica Bulgarica, 71: 241-246.

ČejKa T., ČaČanÝ J., Horsák M., JuřičKová L., BuĎová J., Duda M., Holubová A., Horsáková V., Jansová A., Kocurková A., KorÁBeK O., MaŇAs M., ŘíHOvá D. \& Šizling A. L., 2015: Vodné mäkkýše ochranársky významných lokalít na Podunajskej nížine [Freshwater molluscs of water bodies with a high conservation value in the Danubian lowland (SW Slovakia)]. - Malacologica Bohemoslovaca, 14: 5-16. (in Slovak).

ČEJKA T. \& ČAČANÝ J., 2014: The first record of the Turkish snail (Helix lucorum L., 1758) in the Slovak Republic. - Malacologica Bohemoslovaca, 13: 124-125.

ČEJKA T., ČERneCKÝ J. \& Duricová V., 2019: Preverenie výskytu druhu európskeho významu Anisus vorticulus na základe požiadaviek Európskej komisie na východnom Slovensku [Verification of the occurrence of Anisus vorticulus, a species of European importance, based on the requirements of the European Commission in eastern Slovakia]. - Výskumná správa [Research report], ms., depon. in Štátna ochrana prírody, Banská Bystrica, 22 pp. (in Slovak).

ČEJKA T., DvořÁK L. \& HorsáK M., 2006: Malakologické novinky na Slovensku v poslednom štvrt'storočí [Malacofaunistical news in the Slovakia during last 25 years]. - In: Zoologické dny Brno 2006, Bryja J. \& Zukal J. (eds), sborník abstraktů z konference, Brno 9.-10. února 2006: 31-32. (in Slovak).

ČIliak M., ČEJKA T. \& DvoŘÁK L., 2016: The first record of Hawaiia minuscula (Binney, 1841) in Slovakia, with some remarks on other greenhouse snails. - Folia Malacologica, 24: 75-80. http://dx.doi.org/10.12657/folmal.024.012

DoležAL J. X., 2020: Hlemýždík zahradní ze Středomoří nedaleko Pražského hradu [The Mediterranean garden snail near the Prague Castle]. - Veronica, 34: 43. (in Czech).

Duda M. \& Mrkvicka A., 2014: Zur Ausbreitung der Neozoen Monacha cantiana (Montagu 1803), Hygromia cinctella 
(Draparnaud 1801), Cepaea nemoralis (Linné 1758) und Cornu aspersum (O. F. Müller 1774) im Südwestlichen Umland von Wien [On the distribution of Monacha cantiana (Montagu 1803), Hygromia cinctella (Draparnaud 1801), Cepaea nemoralis (Linné 1758) und Cornu aspersum (O. F. Müller 1774 in the south-western suburbs of Wien]. - Nachrichtenblatt der ersten Vorarlberger malakologischen Gesellschaft, 21: 11-13. (in German).

DvoŘÁK L., ČEJKA T. \& HorsáK M., 2003: First record of Deroceras panormitanum (Gastropoda: Agriolimacidae) from Slovakia. - Biologia, 58: 917-918.

DvoŘÁK L. \& HoRsáK M., 2004: Slimák pestrý - rarita v blízkosti lidských sídel [Cellar slug - a rarity near human settlements]. - Živa, sample issue, 1: 18. (in Czech).

Frodloví J. \& Horsák M. (under revision): High-resolution mollusc record from the Mituchovci tufa (W Slovakia): a reference for the Holocene succession of Western Carpathian mid-elevation forests. - Boreas.

Gómez-Rodríguez C., Miller K. E., Castillejo J., IglesiasPiñeiro J. \& Baselga A., 2019: Understanding dispersal limitation through the assessment of diversity patterns across phylogenetic scales below the species level. - Global Ecology and Biogeography, 28: 353-364. https://doi.org/10.1111/geb.12857

Gural-Sverlova N., Gleba V. \& Gural R., 2019: Einschleppung von Tandonia kusceri (Pulmonata: Milacidae) nach Transkarpatien und Verbreitung von Tandonia-Arten in der Ukraine [Introduction of Tandonia kusceri (Pulmonata: Milacidae) in Transcarpathia and distribution of Tandonia species in Ukraine]. - Malacologica Bohemoslovaca, 18: 19-26. (in German).

HAusDORF B., 2000a: The genus Monacha in Turkey (Gastropoda: Pulmonata: Hygromiidae). - Archiv für Molluskenkunde, 128: 61-151. https://doi.org/10.1127/arch.moll/128/2000/61

HAusdorf B., 2000b: The genus Monacha in the Western Caucasus (Gastropoda: Hygromiidae). Journal of Natural History, 34: 1575-1594. https://doi.org/10.1080/00222930050117495

HLavéČ J. \& HorsáK M., 2000: Nový výskyt plzáka Arion intermedius Normand, 1852 (Pulmonata: Arionidae) v CHKO Šumava (Západní Čechy) [The slug Arion intermedius Normand, 1852 (Pulmonata: Arionidae) - new find in the Šumava Protected Landscape Area (Western Bohemia)]. - Silva Gabreta, 5: 113-120. (in Czech).

Hlaváč J. Č. \& Peltanová A., 2010: First occurrence of the Kentish Snail Monacha cantiana (Mollusca: Gastropoda: Hygromiidae) in the Czech Republic. - Malacologica Bohemoslovaca 9: 11-15.

HoRÁČKOvÁ J., 2019: Malakologický inventarizační průzkum navrhované MZCHÚ Houžetín [Malacological inventory of the Houžetín Proposed Protected Area]. - Ms., depon. in SCHKO České středohoří, Litoměřice and AOPK ČR, Praha, 18 pp. (in Czech).

HorÁČKOVÁ J., LožEK V., BERAN L., JUŘIČKOvá L., PODROUŽKovÁ Š., Peterka J. \& Čech M., 2014: Měkkýši údolí Vltavy (Čechy) [Mollusc fauna of the Vltava valley (Bohemia)]. Malacologica Bohemoslovaca, 13: 12-105. (in Czech).

HorsÁK M., 2000: Drobnička žebernatá - Truncatellina costulata (Nilsson) [Bulging Whorl Snail - Truncatellina costulata (Nilsson)]. - Ochrana prírody, 55: 144-145. (in Czech).

Horsák M., ČejKa T., JuŘičKová L., Beran L., HoráčKová J., HlaváČ J. Č., DvoŘÁK L., HáJeK O., Divíšek J., MaŇas M. \& LožEK V., 2020: Check-list and distribution maps of the molluscs of the Czech and Slovak Republics. - Online at http:// mollusca.sav.sk/malacology/checklist.htm, checklist updated October 1, 2020. https://doi.org/10.5281/zenodo.4062430

HorsÁK M. \& DvořÁK L., 2003: First records of the introduced slug Deroceras panormitanum (Lessona et Pollonera, 1882) from the Czech Republic (Mollusca: Gastropoda: Agriolimaci- dae). - Folia Malacologica, 11: 57-58.

Horsák M., Hájek M., Horsáková V., Hlaváč J., Hájková P., Dítě D., Peterka T., Divíšek J., PotưčKová A. \& Preece R. C., 2017: Refugial occurrence and ecology of the land snail Vertigo lilljeborgi in fen habitats in temperate mainland Europe. - Journal of Molluscan Studies, 83(4): 451-460. https://doi.org/10.1093/mollus/eyx028

HorsÁk M., JuřičKová L. \& PickA J., 2013: Měkkýši České a Slovenské republiky [Molluscs of the Czech and Slovak Republics]. - Nakladatelství Kabourek, Zlín, 270 pp. (in Czech and English).

Horsák M., Naggs F. \& Backeljau T., 2020: Paropeas achatinaceum (Pfeiffer, 1846) and other alien subulinine and opeatine land snails in European greenhouses (Gastropoda, Achatinidae). - Malacologia, 63(1): 123-130. https://doi. org/10.4002/040.063.0112

Horsák M. \& Neumanová K., 2004: Distribution of Pisidium globulare Clessin, 1873 (Mollusca: Bivalvia) in the Czech Republic and Slovakia with notes to its ecology and morphological characters. - Journal of Conchology, 38: 373-381.

HorsáKová V. \& Horsák M., 2018: Vrkoč Geyerův a vrkoč útlý - první nálezy celoevropsky ohrožených plžů ve Slavkovském lese [Geyer's Whorl Snail and Narrow-Mouthed Whorl Snail - the first records of pan-European endangered snails in the Slavkovský les Forest]. - Arnika, 1: 30-33. (in Czech).

Hutchinson J. M. C., Schlitt B. \& Reise H., 2019: Monacha claustralis (Rossmässler 1834), a hygromiid snail new to Germany. - Mitteilungen der Deutschen Malakozoologischen Gesellschaft, 100: 17-22.

JUŘIČKovÁ J. \& KAPOUNEK F., 2009: Helix (Cornu) aspersa (O. F. Müller, 1774) (Gastropoda: Helicidae) in the Czech Republic. - Malacologica Bohemoslovaca, 8: 53-55.

Kerney M. P., Cameron R. A. D. \& Jungbluth J. H., 1983: Die Landschnecken Nord- und Mitteleuropas [Land snails of North and Central Europe]. - Paul Parey, Hamburg u. Berlin, 384 pp. (in German).

KolOUCH L. R., 1996: Hojný výskyt plže tmavoretky bělavé [Abundant occurrence of the Carthusian Snail]. - Živa, 44: 126-127. (in Czech).

Kolouch L. R., 2005: Další lokality tmavoretky bělavé [New evidence of the occurrence of the Cartusian Snail]. - Živa, 53: 123. (in Czech).

KOMzÁK P., BerAn L. \& Horsák M., 2018: The first record of Corbicula fluminea (O. F. Müller, 1774) in Moravia (SE Czech Republic). - Malacologica Bohemoslovaca, 17: 28-30.

KorÁBEK O., ČEJKA T. \& JuŘIČKovÁ L., 2016: Tandonia kusceri (Pulmonata: Milacidae), a slug new for Slovakia. - Malacologica Bohemoslovaca, 15: 3-8.

KoráBek O., JuŘičKová L., Balashov I. \& Petrusek A., 2018: The contribution of ancient and modern anthropogenic introductions to the colonization of Europe by the land snail Helix lucorum Linnaeus, 1758 (Helicidae). - Contributions to Zoology, 87: 61-74. https://doi.org/10.1163/18759866-08702001

KorÁBeK O., JuňičKová L. \& PetruseK A., 2016a: Hlemýžd’ pruhovaný, nový druh pro evropskou i českou faunu [Helix thessalica, a new species for European and Czech fauna]. Živa, 64: 31-34. (in Czech).

KorÁBeK O., JuřičKová L. \& PetruSeK A., 2016b: Splitting the Roman snail Helix pomatia Linnaeus, 1758 (Stylommatophora: Helicidae) into two: redescription of the forgotten Helix thessalica Boettger, 1886. - Journal of Molluscan Studies, 82(1): 11-22. https://doi.org/10.1093/mollus/eyv048

KorÁBeK O., JuŘičKovÁ L. \& PetruseK A., 2020: Inferring the sources of postglacial range expansion in two large European land snails. - Journal of Zoological Systematics and Evolutionary Research (in press). https://doi.org/10.1111/jzs.12368

KouteckÝ D., 2020: Dva nálezy trojzubky stepní (Chondrula 
tridens O. F. Müller, 1774) na Podbořansku (severozápadní Čechy) [Two findings of Chondrula tridens O. F. Müller, 1774 in vicinity of Podbořany town (northwestern Bohemia)]. - Sborník oblastního muzea $\mathrm{v}$ Mostě, řada př́rodovědná, 40: 154-155. (in Czech).

Krumpálová Z. \& Holienková B., 2018: Land snails in the Slovak open-air garden centres. - Ekológia (Bratislava), 37(4): 369-379. https://doi.org/10.2478/eko-2018-0028

Kuchaर̌ P., 1983: Potamopyrgus jenkinsi poprvé v Československu [Potamopyrgus jenkinsi in the Czechoslovakia for the first time]. - Živa, Praha, 31: 23. (in Czech).

LACiNA A. \& Horsák M., 2012: Včelínka ozdobná - další z úspěšných výsadků alpského původu $-\mathrm{z}$ červené knihy našich měkkýšů [Pagodulina pagodula - another successful alpine-origin skydiver]. - Živa, 6: 289-290. (in Czech).

LISICKÝ M., 1986: Z červené knihy našich měkkýšů - pikulík Pagodulina pagodula [From the red data book of our molluses - snail Pagodulina pagodula]. - Živa, 2: 61. (in Czech).

Lopes-Lima M., Kebapçı U. \& Van Damme D., 2014: Unio crassus. The IUCN Red List of Threatened Species 2014: e. T22736A42465628. Online at http://dx.doi.org/10.2305/IUCN. UK.2014-1.RLTS.T22736A42465628.en, accessed July 19, 2020.

Lorencová E., Beran L., Horsáková V. \& HorsáK M., 2015: Invasion of freshwater molluscs in the Czech Republic: time course and environmental predictors. - Malacologia, 59: 105120. https://doi.org/10.4002/040.059.0107

LoŽEK V., 1947: Malakozoologické novinky z ČSR. I. [Malacozoological news from Czechoslovakia I.]. - Časopis národního musea, 116, 2: 125-134. (in Czech).

LožEK V., 1960: Malakozoologické novinky z ČSR. VI. [Malacozoological news from Czechoslovakia VI.]. - Časopis národního musea, 129, 1: 72-78. (in Czech).

LožEK V., 1986: Pagodulina pagodula v československém kvartéru [Pagodulina pagodula in the Czechoslovak Quaternary]. - Živa, 2: 61. (in Czech).

LožEK V., 1999: Jihoevropský plž Monacha cartusiana v Českém krasu [South European snail Monacha cartusiana in the Bohemian Karst]. - Živa, 47: 175. (in Czech).

LožEK V. \& VAŠ́́TKo J., 1997: Měkkýši národního parku Podyjí [Molluscs of the Podyjí National Park]. - Česká speleologická společnost, Zlatý kůn̆, Praha, 67 pp. (in Czech).

MáchA S., 1982: Revizní malakozoologický výzkum Poodří [Revision of of the malacozoological research of the Poodři Region]. - Časopis Slezského Muzea Opava (A), 31: 97-106. (in Czech).

MÁcha S., 1988: Další nový druh měkkýše v našich sklenících Hawaia minuscula (Binney, 1840) [Another new mollusc species in our greenhouses - Hawaia minuscula (Binney, 1840)] - Časopis Slezského Muzea Opava (A), 37: 63-64. (in Czech). Manganelli G., Salomone N. \& Giusti F., 2005: A molecular approach to the phylogenetic relationships of the western palaearctic Helicoidea (Gastropoda: Stylommatophora). - Biological Journal of the Linnean Society, 85: 501-512. https:// doi.org/10.1111/j.1095-8312.2005.00514.x

Metcalf A. L. \& SmartT R. A., 1997: Land snails of New Mexico. - Bulletin - New Mexico Museum of Natural History and Science, 10: 1-145.

Mienis H. K., 2015: Nogmaals Eobania vermiculata in Purmerend [Once again Eobania vermiculata in Purmerend]. - Spirula, 402: 15. (in Dutch).

Mienis H. K., RitTNer O. \& VAisman S., 2017: Information concerning Eobania vermiculata, II. On the presence of extra-territorial material in the National Mollusc Collections in Israel (Mollusca, Gastropoda, Helicidae). - Triton, 35: 15-22.

MYšÁk J., 2011: Nové poznatky a revize rozšíření některých vzácných a ohrožených měkkýšů ve východních Čechách
[New findings and checking survey of the distribution of some rare and endangered molluscs in Eastern Bohemia]. - Východočeský sborník př́rodovědný: Práce a studie, 18: 141-148. (in Czech).

Neiber M. T. \& Hausdorf B., 2017: Molecular phylogeny and biogeography of the land snail genus Monacha (Gastropoda, Hygromiidae). - Zoologica Scripta, 46: 308-321. https://doi. org/10.1111/zsc. 12218

Nitz B., Hyman I., Schneppat U. E., Knechtle F., Heim R. \& HASZPRUNAR G., 2013: Back to the roots of the genus Limax: A framework based on an integrated taxonomic approach. - In: Roots of the genus Limax: An integrated taxonomic approach, Nitz B. Doctoral thesis, Fakultät für Biologie der Ludwig-Maximilians-Universität München: 81-115.

NovÁK J. \& NovÁK M., 2013: Nález drobničky žebernaté Truncatellina costulata (Nilsson, 1822) v PR Šibeničník u Mikulova [New find of Truncatellina costulata (Nilsson, 1822) in the Šibeničník Natural Reserve near Mikulov (South Moravia, Czech Republic)]. - Malacologica Bohemoslovaca, 12: 14-16. (in Czech).

PÁll-Gergely B., Fehér Z. \& ČejKa T., 2020: Appearance of the Mediterranean land snail Massylaea vermiculata $(\mathrm{O} . \mathrm{F}$. Müller, 1774) in Hungary and Slovakia. - Folia Malacologica, 28(4): 5 pp. https://doi.org/10.12657/folmal.028.021

Páll-Gergely B., Majoros G., Domokos T., Juhász A., TuróCi Á., Badacsonyi L., Fekete J. \& Asami T. 2019: Realtime Social Networking Service rapidly reveals distributions of nonindigenous land snails in a European capital. - BioInvasions Records, 8(4): 782-792, https://doi.org/10.3391/bir.2019.8.4.06 Peltanoví A., Dvořák L. \& JuŘičKová L., 2012: The spread of non-native Cepaea nemoralis and Monacha cartusiana (Gastropoda: Pulmonata) in the Czech Republic with comments on other land snail immigrants. - Biologia, 67: 384-389.

Peltanová A., Petrusek A., Kment P. \& Juřičková L., 2012: A fast snail's pace: colonization of Central Europe by Mediterranean gastropods. - Biological Invasions, 14: 759-764.

Piechocki A. \& Wawrzyniak-Wydrowska B., 2016: Guide to Freshwater and Marine Mollusca of Poland. Bogucki Wydawnictvo Naukove, Poznań.

Pieńkowska J. R., Manganelli G., Giusti F. \& Lesicki A., 2015: Monacha claustralis (Rossmässler 1834) new to Polish and Czech malacofauna (Gastropoda: Pulmonata: Hygromiidae). - Journal of Conchology, 42: 79-93.

Pieńkowska J. R., Proćków M, Górka M. \& Lesicki A., 2018: Distribution of Monacha claustralis (Rossmässler, 1834) and M. cartusiana (O. F. Müller, 1774) (Eupulmonata: Hygromiidae) in Central European and Balkan countries: new data. Folia Malacologica, 26: 103-120. https://doi.org/10.12657/ folmal.026.009

Pieńkowska J. R., Rybska E., Banasiak J., Wesolowska M. \& LeSICKI A., 2015: Taxonomic status of Stagnicola palustris (O. F. Müller, 1774) and S. turricula (Held, 1836) (Gastropoda: Pulmonata: Lymnaeidae) in view of new molecular and chorological data. - Folia Malacologica, 23: 3-18. http://dx.doi. org/10.12657/folmal.023.003

PodroužKová Š., LožEK V., JuŘičKová L., HoráčKová J., Beran L. \& HlaváČ J., 2020: Měkkýši Českého krasu [Molluscs of the Bohemian Karst]. - Prríroda, Praha, 40, 296 pp. (in Czech).

Ponec J., 1967: Mollusca Malých Karpát [Mollusca of the Malé Karpaty Mts]. - Diploma thesis, Prírodovedecká fakulta UK, Bratislava, 80 pp. (in Slovak).

PoneC J., 1972: Mollusca Malých Karpát [Mollusca of the Malé Karpaty Mts]. - Acta rerum naturalium Musei Nationalis Slovaci, 18: 71-114. (in Slovak).

Razkin O., Sonet G., Breugelmans K., Madeira M. J., Gómez-Moliner B. J. \& Backeljau T., 2016: Species limits, 
interspecific hybridization and phylogeny in the cryptic land snail complex Pyramidula: the power of RADseq data. - Molecular Phylogenetics and Evolution, 101: 267-278. https://doi. org/10.1016/j.ympev.2016.05.002

Ronsmans J. \& VAN DEN Neucker T., 2016. A persistent population of the chocolate-band snail Eobania vermiculata (Gastropoda: Helicidae) in Belgium. - Belgian Journal of Zoology, 146: 66-68. https://doi.org/10.26496/bjz.2016.41

Rowson B., Anderson R., Turner J. A. \& Symondson W. O. C., 2014: The slugs of Britain and Ireland: undetected and undescribed species increase a well-studied, economically important fauna by more than 20\%. - PLoS ONE, 9: e91907. https:// doi.org/10.1371/journal.pone.0091907

ŘíHová D. \& JuŘičKové L., 2011: The Girdled Snail Hygromia cinctella (Draparnaud, 1801) new to the Czech Republic. Malacologica Bohemoslovaca, 10: 35-37.

Schenková V., Horsák M, Plesková Z. \& Pawlikowski P., 2012: Habitat preferences and conservation of Vertigo geyeri (Gastropoda: Pulmonata) in Slovakia and Poland. - Journal of Molluscan Studies, 78(1): 105-111. https://doi.org/10.1093/ mollus/eyr046

Simon O. P., VaníčKová I., Bílý M., Douda K., Patzenhauerová H., HrušKa J. \& Peltánová A., 2015: The status of freshwater pearl mussel in the Czech Republic: Several successfully rejuvenated populations but the absence of natural reproduction. - Limnologica, 50: 11-20. https://doi.org/10.1016/j. limno.2014.11.004

ŠTEFFEK J. \& VAVROVÁ L., 2006: Current ecosozological status of molluscs (Mollusca) of Slovakia in accordance with categories and criterion of IUCN - version 3.1. (2001). - In: Molluscs: Perspective of Development and Investigation, Kyrychuk G. Y. (ed.) conference proceedings, Zytomyr, Ukraine 27-29th September 2006: 266-276.

Turóci Á., Fehér Z., Krízsik V. \& PÁll-Gergely B., 2020:
Two new alien slugs, Krynickillus melanocephalus Kaleniczenko, 1851 and Tandonia kusceri (H. Wagner, 1931), are already widespread in Hungary. - Acta Zoologica Academiae Scientiarum Hungaricae, 66: 265-282. https://doi.org/10.17109/ AZH.66.3.265.2020

UliČNÝ J., 1892-95: Měkkýši čeští [Czech molluscs]. - Přírodovědecký klub, Praha, 208 pp. (in Czech).

van Damme D., 2011: Pseudanodonta complanata. - The IUCN Red List of Threatened Species 2011: e.T18446A8279278. Online at http://dx.doi.org/10.2305/IUCN.UK.2011-2.RLTS. T18446A8279278.en, accessed July 19, 2020.

VAN der Velde G., Rajagopal S. \& Bij de VaAte A. (eds), 2010: The Zebra Mussel in Europe. - Margraf Publishers, Weikersheim, $490 \mathrm{pp}$.

VAŠÁT M., 2019: Rozšíření slimáčků rodu Deroceras v České republice ve vztahu $\mathrm{k}$ faktorům prostředí [Distribution of Deroceras species in the Czech Republic in relation to environmental factors]. - Diploma thesis, Masarykova univerzita: 94+5 pp. Online at https://is.muni.cz/th/ttc5j/DP_Martin_Vasat. pdf (in Czech).

VAš́́TKO J. \& HoRSÁK M., 2000: Měkkýši labské nivy u Přelouče [Molluscs of the Labe River floodplain near Přelouč]. - Východočeský sborník prŕrodovědný Práce a studie, 8: 237-246. (in Czech).

Vavrová L., Horsák M., ŠtefFek J. \& ČEJKa T., 2009: Ecology, distribution and conservation of Vertigo species of the European importance in Slovakia. - Journal of Conchology, 40: 61-71. von Proschwitz T., 1997: Flackig vinbergssnäcka (Cornu aspersum (O. F. Müller) funnen i Sverige [The "common snail" Cornu aspersum (O. F. Müller) found in Sweden]. - Göteborgs Naturhistoriska Museum, Årstryck, 1997: 23-27. (in Swedish). WeLter-Schultes F. W., 2012: European non-marine molluscs: a guide for species identification. - Planet Poster Editions, Göttingen, $679 \mathrm{pp}$

Table 1. Location data of the newly discovered occurences reported herein.

Species; live/empty; Nearest municipality; Coordinates $\left({ }^{\circ} \mathrm{N},{ }^{\circ} \mathrm{E}\right)$; Location (briefly); Date of coll.; Altitude; leg./det.; Citation (if published)

Aegopinella nitidula (Draparnaud, 1805); 3/1; Skalice; 50.48954, 13.89083; České středohoří Mts. PLA, alluvium of the Žejdlík Brook; 22. 9. 2019; 412; J. Horáčková; HoráčKOvá 2019

Anisus septemgyratus (Rossmässler, 1835); 18; Kapušianske Kračany; 48.49965, 22.05591; cutted, terrestrialised meander near the road from the village of Vel'ké Kapušany to village of Leles; 15. 9. 2019; 100; J. Černecký; ČEJKA et at. 2019

Anisus septemgyratus (Rossmässler, 1835); 6; Beša; 48.53080, 21.95047; Beša Meander, S from the village; 15. 9. 2019; 100; J. Černecký; ČEJKA et at. 2019

Anisus septemgyratus (Rossmässler, 1835); 1; Petrikovce; 48.54452, 21.85371; Brehovský kanál Ditch (W from village of Petrikovce); 15. 9. 2019; 100; J. Černecký; ČEJKA et at. 2019

Anisus septemgyratus (Rossmässler, 1835); 5/0; Břeclav; 48.72508, 16.92797; oxbow on the E edge of the deer-park at the cycle path to Lanžhot; 20. 7. 2019; 155; L. Beran

Anisus septemgyratus (Rossmässler, 1835); 15/0; Břeclav; 48.72701, 16.89617; Malý Martinec Pool by the Pohansko Chateau, W margin; 27. 4. 2017; 160; M. Horsák

Anisus septemgyratus (Rossmässler, 1835); 3/0; Senné; 48.66913, 22.03230; area of the Avescentrum in the village of Senné; 28. 6. 2019; 100; M. Horsák

Aplexa hypnorum (Linnaeus, 1758); 60/0; Blatná; 49.00228, 19.16353; Blatné jazero Reservoir; 27. 6. 2017; 794; L. Beran

Arion intermedius Normand, 1852; 1/0; Běstvina; 49.83260, 15.58351; Hlubošský rybník Pond; 16. 7. 2015; 340; M. Horsák 
Arion intermedius Normand, 1852; 1/0; Líska; 50.81275, 14.43744; Lužické hory Mts. PLA, Nolden Teich I. NM; 19. 6. 2015; 365; L. Juřičková a kol.

Arion intermedius Normand, 1852; 1/0; Mařeničky; 50.79500, 14.67555; Lužické hory Mts. PLA, Rašeliniště Mařeničky NM; 20. 6. 2015; 360; L. Juřičková a kol.

Arion intermedius Normand, 1852; 1/0; Kunratice u Cvikova; 50.78282, 14.67374; Lužické hory Mts. PLA, an alluvium under the Dolní Kunratický pond; 20. 6. 2015; 330; L. Juřričková a kol.

Arion intermedius Normand, 1852; 1/0; Srbská Kamenice; 50.82107, 14.35652; Lužické hory Mts. PLA, Arba NM; 24. 6. 2016; 210; L. Juřičková a kol.

Arion intermedius Normand, 1852; 1/0; Horní Podluží; 50.89444, 14.55438; Lužické hory Mts. PLA, Světlík NM; 24. 6. 2016; 593; L. Juřičková a kol.

Arion intermedius Normand, 1852; 1/0; Horní Světlá; 50.84894, 14.64678; Lužické hory Mts. PLA, Luž NM; 25.06.2016; 785; L. Juřičková a kol.

Arion intermedius Normand, 1852; 1/0; Horní Světlá; 50.84885, 14.66115; Lužické hory Mts. PLA, Brazilka NM; 25. 6. 2016; 550; L. Juřičková a kol.

Arion intermedius Normand, 1852; 1/0; Krásná Lípa; 50.91975, 14.49177; Lužické hory Mts. PLA; 25.06.2016; 406; V. Hrdlička

Arion intermedius Normand, 1852; 1/0; Karlovka; 50.73486, 14.41109; České středohoří Mts. PLA, an alluvium of the Vrbový brook; 28. 8. 2019; 346; J. Horáčková

Arion obesoductus P. L. Reischütz, 1973; 1/0; Láz; 49.67012, 13.87276; Brdy; 02. 7. 2019; 738; M. Drvotová

Arion obesoductus P. L. Reischütz, 1973; 1/0; Želízy; 50.42467, 14.46245; Kokořínsko PLA, Liběchovka river flood-plain; 15. 8. 2018; 175; J. Horáčková

Arion obesoductus P. L. Reischütz, 1973; 1/0; Heřmanice v Podještědí; 50.79066, 14.70413; Lužické hory Mts. PLA, Jezevčí vrch NNR, top of the Jezevčí hill; 20. 6. 2015; 663; L. Juřičková a kol.

Arion obesoductus P. L. Reischütz, 1973; 1/0; Vilémov; 49.62740, 16.97775; $1.3 \mathrm{~km} \mathrm{SW,} \mathrm{spruce} \mathrm{forest;} \mathrm{26.} \mathrm{10.} \mathrm{2017;}$ 432; M. Maňas

Balea perversa (Linnaeus, 1758); 5/11; České Žleby; 48.87389, 13.77117; Šumava NP, South Bohemia; 01. 5. 2019; 971; J. Horáčková

Balea perversa (Linnaeus, 1758); 0/1; České Žleby; 48.87389, 13.77117; Šumava NP, South Bohemia; 28. 4. 2018; 971; J. Horáčková

Chondrula tridens (O. F. Müller, 1774); 0/100; Dětaň; 50.19788, 13.32546; Podbořansko; 09. 11. 2015; 410; D. Koutecký, J. Horáčková; KouteckÝ 2020

Chondrula tridens (O. F. Müller, 1774); 0/100; Vrbička; 50.18411, 13.29710; Podbořansko; 19. 4. 2015; 501; D.

Koutecký, J. Horáčková; KouTECKÝ 2020

Chondrula tridens (O. F. Müller, 1774); 4/1; Toužín; 49.07725,15.41756; Toužínské stráně NR; 20. 8. 2019; 470; M. Horsák

Clausilia rugosa (Draparnaud, 1801); 12/0; Horažd'ovice; 49.31557, 13.70919; Šumava foothills, Sušicko-horažd'ovické limestones; 14. 5. 2016; 415; J. Hlaváč

Cochlicopa nitens (Gallenstein, 1852); 8/0; Domanice; 49.29647, 13.90991; Šumava foothills, Strakonické limestones; 11. 8. 2016; 415; J. Hlaváč

Cochlicopa nitens (Gallenstein, 1852); 120/45; Vacenovice; 48.95147, 17.17851; Jezero NR, fen meadow behind the NE edge of the village; 23. 6. 2015; 190; T. Němec

Corbicula fluminea (O. F. Müller, 1774); 4/0; Břeclav; 48.72447, 16.88464; Dyje River; 1. 9. 2019; 146; K. Beran, L. Beran

Corbicula fluminea (O. F. Müller, 1774); 90/0; Hostěnice; 50.43747, 14.16333; Ohře River; 3. 6.2018; 170; L. Beran Corbicula fluminea (O. F. Müller, 1774); 13/0; Ústí nad Labem; 50.65753, 14.04042; Bílina River; 3. 8. 2018; 135; L. Beran

Corbicula fluminea (O. F. Müller, 1774); 13/0; Kostice; 48.73231, 17.01789; Morava River 400 m downstream of a weir; 3. 8. 2019; 156; K. Beran, L. Beran

Corbicula fluminea (O. F. Müller, 1774); 120/0; Hostěnice; 50.43411, 14.15011; canal of the Ohře River in Hostěnice; 4. 6. 2017; 170; L. Beran

Corbicula fluminea (O. F. Müller, 1774); 600/0; Hostěnice; 50.43778, 14.14831; canal of the Ohře River north of Hostěnice; 4. 6. 2017; 170; L. Beran 
Corbicula fluminea (O. F. Müller, 1774); 70/0; Lanžhot; 48.71753, 17.01153; Morava River east of Lanžhot; 5. 10. 2019; 157; K. Beran, L. Beran

Corbicula fluminea (O. F. Müller, 1774); 250/0; Týnec; 48.75383, 17.03987; Morava River E of Týnec; 5. 10. 2019; 158; K. Beran, L. Beran

Corbicula fluminea (O. F. Müller, 1774); 25/0; Moravská Nová Ves; 48.77933, 17.06914; Morava River E of Moravská Nová Ves; 5. 10. 2019; 158; K. Beran, L. Beran

Corbicula fluminea (O. F. Müller, 1774); 3/0; Děčín; 50.77633, 14.20725; Ploučnice River; 8. 9. 2018; 148; L. Beran

Corbicula fluminea (O. F. Müller, 1774); 25/0; Vraňany; 50.31428, 14.35431; Vltava River downstream of a weir; 8. 12. 2015; 168; L. Beran

Corbicula fluminea (O. F. Müller, 1774); 40/0; Lužec nad Vltavou; 50.31931, 14.39711; Vltava River by the ferry; 8. 12. 2015; 164; L. Beran

Corbicula fluminea (O. F. Müller, 1774); 35/0; Račice; 50.44753, 14.32253; SW edge of a canal for rowing in Račice; 8. 12. 2018; 148; L. Beran

Corbicula fluminea (O. F. Müller, 1774); 60/0; Dobříň; 50.43667, 14.30514; SW edge of a sandpit; 12. 8. 2015; 155;

L. Beran

Corbicula fluminea (O. F. Müller, 1774); 250/0; Brozany; 50.45133, 14.14775; canal of the Ohře River; 14. 5. 2017; 156; L. Beran

Corbicula fluminea (O. F. Müller, 1774); 300/0; Brozany; 50.45944, 14.14808; canal of the Ohře River near Brozany; 14. 5. 2017; 156; L. Beran

Corbicula fluminea (O. F. Müller, 1774); 800/0; Brozany; 50.46111, 14.15639; canal of the Ohře River; 14. 5. 2017; 156; L. Beran

Corbicula fluminea (O. F. Müller, 1774); 20/0; Předonín; 50.44561, 14.32983; SE part of the sandpit; 14. 8. 2015; 169; L. Beran

Corbicula fluminea (O. F. Müller, 1774); 23/0; Radotín; 49.97264, 14.34722; Berounka River to the W of Radotín; 19. 9. 2019; 197; L. Beran

Corbicula fluminea (O. F. Müller, 1774); 15/0; Káraný; 50.18336, 14.73053; Jizera River by the bridge; 21. 10. 2019; 173; L. Beran

Corbicula fluminea (O. F. Müller, 1774); 27/0; Přelouč; 50.04389, 15.57333; Labe (Elbe) River downstream of the weir; 25. 7. 2019; 212; L. Beran

Corbicula fluminea (O. F. Müller, 1774); 150/0; Brozany; 50.44564, 14.15306; canal of the Ohře River; 27. 5. 2017; 156; L. Beran

Corbicula fluminea (O. F. Müller, 1774); 4/0; Troja; 50.11361, 14.41241; left bank of the Vltava River along the WWTP; 27. 8. 2017; 195; L. Beran

Corbicula fluminea (O. F. Müller, 1774); 4/0; Troja; 50.11361, 14.42022; left bank of the Vltava upstream of the bridge; 27. 8. 2017; 195; L. Beran

Corbicula fluminea (O. F. Müller, 1774); 15/0; Holešovice; 50.11139, 14.43500; Vltava River downstream of the bridge; 30. 12. 2019; 195; L. Beran

Corbicula fluminea (O. F. Müller, 1774); 13/0; Troja; 50.11494, 14.40319; right bank of the Vltava River along Prague Zoo; 31. 8. 2017; 195; L. Beran

Corbicula fluminea (O. F. Müller, 1774); 0/6; Sedlec (Praha 6); 50.12797, 14.3998; left bank of the Vltava; 31.12. 2017; 194; O. Simon

Cornu aspersum (O. F. Müller, 1774); 1/0; Praha; 50.10350, 14.37440; Praha, Hanspaulka, Na Viničních horách Street; 00. 00. 2017; 297; A. Vránová

Cornu aspersum (O. F. Müller, 1774); 1; Křivenice; 50.40547, 14.43933; cycling trail along the Labe River; 12.5. 2016; 155; L. Beran

Cornu aspersum (O. F. Müller, 1774); 1/0; Bratislava; 48.14673, 17.06386; bank of the Karloveské rameno Branch (cycling trail); 15. 5. 2015; 140; J. Čapka

Cornu aspersum (O. F. Müller, 1774); 1; Křivenice; 50.40547, 14.43933; cycling trail along the Labe River; 18.7. 2016; 155; L. Beran

Cornu aspersum (O. F. Müller, 1774); 3/3; Vígl'aš; 48.54933, 19.30297; Vígl’aš town, horticultural centre; 21. 5. 2015; 358; B. Holienková 
Cornu aspersum (O. F. Müller, 1774); 1; Křivenice; 50.40547, 14.43933; cycling trail along the Labe River; 22. 6. 2016; 155; L. Beran

Cornu aspersum (O. F. Müller, 1774); 2; Křivenice; 50.40547, 14.43933; cycling trail along the Labe River; 22. 7. 2016; 155; L. Beran

Cornu aspersum (O. F. Müller, 1774); few shells; Praha; 50.07050, 14.42540; Praha, Albertovské stráně; 24. 5. 2018; 225; O. Korábek

Cornu aspersum (O. F. Müller, 1774); 5/0; Bratislava; 48.15838, 17.06987; atrium with a children's park within the residential zone of the Cubicon shopping center; 25. 7. 2018; 175; J. Čapka

Deroceras invadens Reise, Hutchinson, Schunack \& Schlitt, 2011; 5; Stupava; 48.27399, 17.02794; Stupava Town, garden, Marcheggská Street; 18. 2. 2018; 176; T. Čejka; ČEJKA 2018a

Deroceras invadens Reise, Hutchinson, Schunack \& Schlitt, 2011; 4; Zlín; 49.24000, 17.68583; Vršava, family cabin garden; below paving stones; 6. 10. 2018; 259; M. Vašát; VAŠÁT 2019

Deroceras juranum Wüthrich, 1993; 1/0; Horní Planá; 48.74104, 14.01666; Šumava NP and PLA, stream-mouth of the Hamerský Brook; 13. 10. 2018; 733; J. Horáčková, M. Horsák; VAš́́t 2019

Deroceras juranum Wüthrich, 1993; 1/0; Želnava; 48.81820, 13.95100; Šumava NP and PLA, floodplain of the Starý brook; 13. 10. 2018; 732; J. Horáčková, M. Horsák; VAŠáT 2019

Deroceras juranum Wüthrich, 1993; 1/0; Stožec; 48.86117, 13.87275; Šumava NP and PLA, Mrtvý luh, floodplain of the Studená Vltava River; 13. 10. 2018; 750; J. Horáčková, M. Horsák; VAŠ́́t 2019

Deroceras juranum Wüthrich, 1993; 2/0; České Žleby; 48.87230, 13.77180; Šumava NP and PLA, Žlebský vrch foothill; 13. 10. 2018; 952; J. Horáčková, M. Horsák; VAŠ́́ 2019

Deroceras juranum Wüthrich, 1993; 1/0; Dobrá; 48.88527, 13.84809; Šumava NP and PLA, small brook floodplain; 13. 10. 2018; 746; J. Horáčková, M. Horsák; VAš́́́ 2019

Deroceras juranum Wüthrich, 1993; 5/0; Líska; 50.83055, 14.45555; Lužické hory Mts. PLA, Studený vrch NR; 19. 6. 2015; 680; M. Horsák; VAšát 2019

Deroceras juranum Wüthrich, 1993; 1/0; Volary; 48.89610, 13.88480; Šumava NP and PLA, Luční brook floodplain; 20. 10. 2018; 748; M. Vašát, M. Horsák; VAŠát 2019

Deroceras juranum Wüthrich, 1993; 1/0; Svinná Lada; 48.99521, 13.65465; Šumava NP and PLA, Teplá Vltava River floodplain; 20. 10. 2018; 895; M. Vašát, M. Horsák; VAŠÁt 2019

Deroceras juranum Wüthrich, 1993; 2/0; Smolná Pec; 48.85858, 13.89202; Šumava NP and PLA, Mrtvý luh, floodplain of the Vltava River; 26. 10. 2018; 732; J. Horáčková, M. Horsák; VAš́́t 2019

Deroceras juranum Wüthrich, 1993; 1/0; Volary; 48.87513, 13.88397; Šumava NP and PLA, Mrtvý luh, floodplain of the Vltava River; 26. 10. 2018; 730; J. Horáčková, M. Horsák; VAšát 2019

Deroceras juranum Wüthrich, 1993; 1/0; České Žleby; 48.87907, 13.76926; Šumava NP and PLA, Žlebský vrch foothill; 28. 4. 2018; 965; J. Horáčková, M. Horsák; VAŠ́́T 2019

Deroceras juranum Wüthrich, 1993; 1/0; České Žleby; 48.89397, 13.78644; Šumava NP and PLA, Radvanovický Ridge; 28. 4. 2018; 995; J. Horáčková, M. Horsák; VAŠÁT 2019

Deroceras juranum Wüthrich, 1993; 2/0; České Žleby; 48.89791, 13.78536; Šumava NP and PLA, Radvanovický Ridge; 28. 4. 2018; 904; J. Horáčková, M. Horsák; VAš́́T 2019

Deroceras juranum Wüthrich, 1993; 1/0; České Žleby; 48.90115, 13.79515; Šumava NP and PLA, Radvanovický Ridge; 28. 4. 2018; 874; J. Horáčková, M. Horsák; VAŠ́́í 2019

Deroceras juranum Wüthrich, 1993; 1/0; Dobrá; 48.88024, 13.83833; Šumava NP and PLA, Stožec Hill; 29. 4. 2018; 905; J. Horáčková, M. Horsák; VAŠÁT 2019

Deroceras juranum Wüthrich, 1993; 2/0; Dobrá; 48.88169, 13.82695; Šumava NP and PLA, Stožec Hill; 29. 4. 2018; 1021; J. Horáčková, M. Horsák; VAŠ́́t 2019

Deroceras juranum Wüthrich, 1993; 1/0; Dobrá; 48.88381, 13.82286; Šumava NP and PLA, Stožec Hill; 29. 4. 2018; 940; J. Horáčková, M. Horsák; VAš́́́ 2019

Dreissena bugensis Andrusov, 1897; 126; Hamuliakovo; 48.03293, 17.24742; littoral of the left bank of the Gabčíkovo Reservoir; 18. 10. 2013; 176; T. Čejka

Dreissena bugensis Andrusov, 1897; 0/?; Zlatná na Ostrove; 47.75000, 17.95100; Vel'kolélsky ostrov, left bank of the Danube River; 26. 9. 2014; 107; M. Horsák; ČEJKA et al. 2015

Dreissena bugensis Andrusov, 1897; 0/1; Radvaň nad Dunajom; 47.74780, 18.37660; left bank of the Danube River; 27. 9. 2014; 106; M. Horsák; Č́JKA et al. 2015 
Euomphalia strigella (Draparnaud, 1801); 47/0; Brloh; 49.32803, 14.01194; Šumava foothills, Strakonické limestones; 7. 5. 2015; 420; J. Hlaváč

Ferrissia californica (Rowell, 1863); 3/0; Klokočov; 48.80822, 22.02931; N bank of the Zemplínská Š́rava dam reservoir; 25. 6. 2019; 114; L. Beran; BERAN 2020a

Ferrissia californica (Rowell, 1863); 2/0; Sokolov; 50.18867, 12.59598; shallow pool N of Medard Lake; 25. 8. 2018; 420; L. Beran; BERAN 2019a

Ferrissia californica (Rowell, 1863); 14/0; Kynšperk nad Ohří; 50.12286, 12.51883; southern pool by the railway station; 30. 9. 2018; 400; L. Beran

Gyraulus acronicus (A. Férussac, 1807); 6/0; Vlašim; 49.70103, 14.87625; Blanice River; 5. 11. 2017; 348; L. Beran; Beran 2020b

Gyraulus acronicus (A. Férussac, 1807); 6/0; Radonice; 49.79464, 14.93267; Blanice River NW of Radonice; 6. 10. 2018; 308; L. Beran; BERAN 2020b

Gyraulus acronicus (A. Férussac, 1807); 6/0; Louňovice pod Blaníkem; 49.64994, 14.85889; Blanice River upstream of the bridge; 10. 11. 2018; 375; L. Beran; BERAN 2020b

Gyraulus acronicus (A. Férussac, 1807); 12/0; Červená Řečice; 49.51861, 15.19250; right bank of the Trnávka dam reservoir; 12. 7. 2015; 455; L. Beran; BERAN 2020b

Gyraulus acronicus (A. Férussac, 1807); 14/0; Znosim; 49.69958, 14.87394; Blanice River; 24. 10. 2015; 350; L. Beran; BERAN 2020b

Gyraulus acronicus (A. Férussac, 1807); 7/5; Sušice; 49.25180, 13.52986; Ostružná creek; 29. 9. 2015; 468; J. Bojková

Gyraulus parvus (Say, 1817); 4/0; Námestovo; 49.40164, 19.51267; bank of the Orava dam reservoir; 16. 8. 2016; 612; L. Beran

Gyraulus parvus (Say, 1817); 4/0; Námestovo; 49.40711, 19.51478; Orava Reservoir in Slavický ostrov island; 16.8. 2016; 612; L. Beran

Gyraulus parvus (Say, 1817); 35/0; Klokočov; 48.80861, 22.03881; overgrown bight of the Zemplínská Š́rava Reservoir; 24. 6. 2019; 114; L. Beran; BERAN 2020a

Gyraulus parvus (Say, 1817); 300/0; Michalovce; 48.77781, 21.95397; W edge of the Zemplínská Sírava Reservoir; 25. 6. 2019; 114; L. Beran; BERAN 2020a

Gyraulus parvus (Say, 1817); 150/0; Vinné; 48.78878, 21.94653; Zemplínská Š́rava Reservoir at the inflow of the canal; 25. 6. 2019; 114; L. Beran; BERAN 2020a

Gyraulus parvus (Say, 1817); 250/0; Klokočov; 48.80822, 22.02931; N edge of the Zemplínská Š́rava Reservoir; 25. 6. 2019; 114; L. Beran; BERAN 2020a

Gyraulus parvus (Say, 1817); 7/0; Malé Zalužice; 48.76669, 21.99328; S edge of the Zemplínská Š́rava Reservoir; 26. 6. 2019; 114; L. Beran; BERAN 2020a

Gyraulus rossmaessleri (Auerswald, 1851); 3/0; Doubravice; 49.74147, 16.99294; temporary wetland by the Morava River; 9. 6. 2018; 242; L. Beran

Gyraulus rossmaessleri (Auerswald, 1851); 40/0; Stupava (ČR); 49.09713, 17.22197; U Mísy Spring; 15. 5. 2015; 455; M. Horsák

Gyraulus rossmaessleri (Auerswald, 1851); 28/0; Háj ve Slezsku; 49.90308, 18.08817; ditch by a road near the Opava River; 18. 4. 2015; 224; L. Beran

Gyraulus rossmaessleri (Auerswald, 1851); 60/0; Háj ve Slezsku; 49.90997, 18.10044; temporary ditch by a road; 18. 4. 2015; 224; L. Beran

Gyraulus rossmaessleri (Auerswald, 1851); 12/0; Zábřeh; 49.91739, 18.06717; Koutské and Zábřežské louky Meadows NR; 19. 4. 2015; 225; L. Beran

Gyraulus rossmaessleri (Auerswald, 1851); 35/0; Kouty; 49.91772, 18.05572; sedge wetlands in a meadow; 19.4. 2015; 225; L. Beran

Gyraulus rossmaessleri (Auerswald, 1851); 8/0; Přestanov; 50.69003, 13.92639; wetlands by a small pond; 22.8 . 2017; 210; L. Beran

Hawaiia minuscula (Binney, 1841); 2/3; Zvolen; 48.59452, 19.13516; Borová hora Arboretum; 10. 10. 2015; 330; T. Čejka, M. Čiliak; ČILIAK et al. 2016

Helix cf. thessalica; 3; Dudince; 48.1650, 18.8800; hill slope above the spa; 19. 7. 1987; 148; O. Korábek 
Helix lucorum Linnaeus, 1758; 3; Nitra; 48.31196, 18.09263; Wilsonovo nábrežie Waterfront; 13. 5. 2016; 145 ; J. Kollár

Helix thessalica O. Boettger, 1886; 1; Hájnačka; 48.21792, 19.95536; Hájnačka Castle ruin; 4. 5. 2016; 298; T. Čejka, J. Čačaný

Helix thessalica O. Boettger, 1886; - ; Nová Bašta; 48.17064, 19.94396; garden of the Pohanský Hrad boarding house (Pogányvár Panzió); 25. 5. 2016; 260; V. Janský

Hygromia cinctella (Draparnaud, 1801); 2/5; Bratislava; 48.15125, 17.031435; Karlova Ves, Devínska cesta Road; 7. 8. 2015; 142; T. Čejka; ČEJKA 2015b

Ladislavella occulta (Jackiewicz, 1959); 2/0; Lanžhot; 48.66161, 16.95217; small pools in a meadow; 5. 5. 2018; 152; L. Beran

Ladislavella occulta (Jackiewicz, 1959); 4/0; Lanžhot; 48.66217, 16.95200; small ditch; 5. 5. 2018; 152; L. Beran

Ladislavella occulta (Jackiewicz, 1959); 10/0; Kolesa; 50.08066, 15.48013; small pool by the road; 13. 5. 2017; 221;

L. Beran

Ladislavella occulta (Jackiewicz, 1959); 30/100; Senné; 48.66913, 22.03230; area of the Avescentrum in the village of Senné; 28. 6. 2019; 100; M. Horsák

Limacus flavus (Linnaeus, 1758); 3; Cabaj-Čápor; 48.25410, 18.01578; N edge of the village; 1. 9. 2016; 165; J. Kollár

Limacus flavus (Linnaeus, 1758); 2; Kardašova Řečice; 49.18358, 14.85147; J. Hrubý Square; 2. 1. 2015; 440; L. Dvořák

Limacus flavus (Linnaeus, 1758); 2; Drnholec; 48.86021, 16.48482; garden of a family house opposite the school; 8. 3. 2015; 200; R. Vlk

Limacus flavus (Linnaeus, 1758); 2; Lednice; 48.80676, 16.81736; park in the village; 14. 6. 2019; 185; R. Coufal

Limacus flavus (Linnaeus, 1758); 30; Zavar; 48.34730, 17.66890; Hlavná Street No. 550; 15. 8. 2016; 138; Š. Buchta lgt.

Limacus flavus (Linnaeus, 1758); 3; Drnholec; 48.86021, 16.48482; cellar of a family house opposite the school; 19. 1. 2015; 200; R. Vlk

Limacus flavus (Linnaeus, 1758); 6; Břeclav; 48.75794, 16.88578; flood wall of the river Dyje in the city center; 26.7. 2016; 159; M. Chytrý, L. Jurek

Limacus flavus (Linnaeus, 1758); 1; Lednice; 48.7987, 16.8021; Lednice, Valtická St; 26. 10. 2019; 175; O. Korábek Eimaeus flavus (Linnaets, 1758) Limacus maculatus (Kaleniczenko, 1851); 6; Valtice; 48.74921, 16.79418; Boř́i les, Rendez-vous NM; 30. 7. 2019; 200; V. John

Margaritifera margaritifera (Linnaeus, 1758); scattered; Dolní Př́íbrní-Dolní Dvořiště; 48.62852, 14.60626-48.66039, 14.47452; upper Malše River, South Bohemia; 2017-2019; 752-603; J. Horáčková, V. Stupková, O. Simon a kol.

Margaritifera margaritifera (Linnaeus, 1758); scattered; Soumarský Most-Nová Pec; 48.90841, 13.82527-48.79743, 13.94702; Teplá Vltava River and upper Vltava River; 2018-2019; 750-725; J. Horáčková, J. Švanyga, O. Simon a kol.

Massylaea vermiculata (O. F. Müller, 1774); 2/0; Bratislava; 48.15132, 17.03121; Karlova Ves district, horticultural centre „Agapé“; 15. 6. 2019; 142; J. Čapka; ČEJKA 2019a

Menetus dilatatus (Gould, 1841); 3/0; Bolevec; 49.78600, 13.38336; Třemošenský rybník Pond; 1. 1. 2015 - 31.12. 2015; 350; Anonymus, L. Beran

Menetus dilatatus (Gould, 1841); 40/0; Varvažov; 50.71306, 13.95317; E part of Oprán quarry; 22. 8. 2017; $290 ;$ L. Beran

Menetus dilatatus (Gould, 1841); 23/0; Lohenice; 50.04583, 15.60806; sandpit between Lohenice and Labiště; 25.7. 2019; 212; L. Beran

Pagodulina pagodula (Des Moulins, 1830); 2/6; Vranov nad Dyjí; 48.89013, 15.82551; valley opposite the Zadní Hamry settlement; 18. 7. 2018; 322; R. Coufal

Pagodulina pagodula (Des Moulins, 1830); 30/10; Staré Hobzí; 48.99547,15.43725; Mutenská obora NR, 660 m NW of the Dubová hill (538 m a.s.1.); 20. 8. 2019; 460; M. Horsák

Pagodulina pagodula (Des Moulins, 1830); 20/10; Staré Hobzí; 48.99553,15.43539; Mutenská obora NR, 660 m NW of the Dubová hill (538 m a.s.1.); 20. 8. 2019; 465; M. Horsák

Pisidium amnicum (O. F. Müller, 1774); 4/0; Česká Lípa; 50.68022, 14.57988; Ploučnice River; 1. 10. 2015; 248; J. Bojková 
Pisidium amnicum (O. F. Müller, 1774); 1/0; Šárovcova Lhota; 50.40611, 15.58000; Lukavecký potok ca 500 m upstream of its inflow into the Javorka Brook; 2. 10. 2016; 282; L. Beran

Pisidium amnicum (O. F. Müller, 1774); 2/0; Šárovcova Lhota; 50.40611, 15.57556; Lukavecký potok ca $100 \mathrm{~m}$ upstream of its inflow into the Javorka Brook; 2. 10. 2016; 282; L. Beran

Pisidium amnicum (O. F. Müller, 1774); 3/0; Medonosy; 50.49558, 14.48867; canal of the Liběchovka Brook; 4. 6. 2017; 170; L. Beran

Pisidium amnicum (O. F. Müller, 1774); 18/0; Bohušovice nad Ohř́́; 50.49389, 14.15806; Ohře River by a bridge in Bohušovice nad Ohř́; 04.08.2018; 150; L. Beran

Pisidium amnicum (O. F. Müller, 1774); 80/0; Žd'ár; 50.54789, 15.06419; canal of the Žehrovka Brook; 05.05.2019; 237; V. Beranová, L. Beran

Pisidium amnicum (O. F. Müller, 1774); 16/0; Žd’ár; 50.54831, 15.06500; Žehrovka Brook upstream of the Žabakor Pond; 05.05.2019; 237; V. Beranová, L. Beran

Pisidium amnicum (O. F. Müller, 1774); 18/0; Doubrava; 50.55061, 15.05901; Žehrovka Brook by the cemetery; 5. 5. 2019; 237; V. Beranová, L. Beran

Pisidium amnicum (O. F. Müller, 1774); 30/0; Brenná; 50.65111, 14.63000; Ploučnice River upstream of a bridge; 5. 8. 2015; 295; L. Beran; BERAN 2016b

Pisidium amnicum (O. F. Müller, 1774); 20/0; Hradčany nad Ploučnicí; 50.62417, 14.68113; Ploučnice River south of Tvarožník hill (321 m a. s. 1.); 5. 8. 2015; 265; L. Beran; Beran 2016b

Pisidium amnicum (O. F. Müller, 1774); 3/0; Ruda; 50.11375, 13.87581; Klíčava Brook 1 km downstream of the Pilský rybník Pond; 5. 11. 2016; 225; L. Beran

Pisidium amnicum (O. F. Müller, 1774); 8/0; Osek nad Bečvou; 49.50972, 17.53694; canal of the Bečva River; 5. 11. 2016; 225; L. Beran

Pisidium amnicum (O. F. Müller, 1774); 6/0; Lány; 50.10494, 13.87903; Klíčava Brook; 9. 9. 2018; 345; L. Beran

Pisidium amnicum (O. F. Müller, 1774); 5/0; Bohušovice nad Ohř́́; 50.49389, 14.15806; Ohře River by a bridge in Bohušovice nad Ohř́; 10. 8. 2015; 150; L. Beran

Pisidium amnicum (O. F. Müller, 1774); 4/0; Brozany; 50.44564, 14.15306; canal of the Ohře River; 14. 5. 2017; 156; L. Beran

Pisidium amnicum (O. F. Müller, 1774); 2/0; Brozany; 50.45083, 14.14808; canal of the Ohře River; 14. 5. 2017; 156; L. Beran

Pisidium amnicum (O. F. Müller, 1774); 4/0; Heřmaničky; 50.66344, 14.60819; Ploučnice ca 250 m downstream of a bridge; 15. 9. 2015; 255; L. Beran; BERAN 2016b

Pisidium amnicum (O. F. Müller, 1774); 1/0; Malé Žernoseky; 50.53829, 14.06089; Labe (Elbe) River; 8. 5. 2013; 145; M. Straka, M. Horsák

Pisidium amnicum (O. F. Müller, 1774); 2/0; Velké Žernoseky; 50.53958, 14.06208; Labe (Elbe) River by the ferry in Velké Žernoseky; 15. 9. 2019; 149; V. Beranová, L. Beran

Pisidium amnicum (O. F. Müller, 1774); 3/0; Hled'sebe; 50.36747, 14.56069; Pšovka Brook near Hled'sebe; 15.11. 2017; 198; L. Beran

Pisidium amnicum (O. F. Müller, 1774); 120/0; Medonosy; 50.49567, 14.48881; Liběchovka Brook upstream of Medonosy; 16. 8. 2017; 200; L. Beran

Pisidium amnicum (O. F. Müller, 1774); 8/0; Šárovcova Lhota; 50.40528, 15.58361; Lukavecký potok by a road; 16. 9. 2018; 282; L. Beran

Pisidium amnicum (O. F. Müller, 1774); 2/0; Šárovcova Lhota; 50.40611, 15.57556; Lukavecký potok ca 100 m upstream of its inflow into the Javorka Brook; 16. 9. 2018; 282; L. Beran

Pisidium amnicum (O. F. Müller, 1774); 2/0; Ruda; 50.10483, 13.88192; Klíčava Brook upstream of the road Lány Zbečno; 17. 12. 2016; 412; L. Beran

Pisidium amnicum (O. F. Müller, 1774); 8/0; Ruda; 50.11705, 13.87192; Klíčava Brook 0.8 km downstream of the Pilský rybník Pond; 17. 12. 2016; 412; L. Beran

Pisidium amnicum (O. F. Müller, 1774); 35/0; Brozany; 50.45133, 14.14775; canal of the Ohře River; 17. 12. 2016; 412; L. Beran

Pisidium amnicum (O. F. Müller, 1774); 17/0; Podlažany; 50.51028, 15.18064; Žehrovka Brook ca $100 \mathrm{~m}$ upstream of confluence with the Jordánka Brook; 18. 5. 2019; 260; V. Beranová, L. Beran 
Pisidium amnicum (O. F. Müller, 1774); 13/0; Podlažany; 50.51131, 15.17528; Žehrovka Brook near Podlažany; 18. 5. 2019; 255; V. Beranová, L. Beran

Pisidium amnicum (O. F. Müller, 1774); 13/0; Lažany; 50.51431, 15.16667; Žehrovka Brook downstream of a road; 18. 5. 2019; 255; V. Beranová, L. Beran

Pisidium amnicum (O. F. Müller, 1774); 10/0; Heřmaničky; 50.66411, 14.61014; Ploučnice river by a bridge; 20.9 . 2018; 255; L. Beran

Pisidium amnicum (O. F. Müller, 1774); 16/0; Heřmaničky; 50.66564, 14.60450; Ploučnice river by a small bridge; 20. 9. 2018; 255; L. Beran

Pisidium amnicum (O. F. Müller, 1774); 23/0; Litoměřice; 50.52858, 14.13444; confluence of rivers Labe and Ohře; 20. 10. 2019; 148; J. Beran, L. Beran

Pisidium amnicum (O. F. Müller, 1774); 28/0; Vlčí Důl; 50.66039, 14.62058; Ploučnice River S of Vlčí Důl; 21. 7. 2015; 260; L. Beran; BERAN 2016b

Pisidium amnicum (O. F. Müller, 1774); 300/0; Křenovy; 50.49464, 15.22211; Žehrovka Brook downstrem of the pond Doly; 22. 6. 2019; 269; V. Beranová, L. Beran

Pisidium amnicum (O. F. Müller, 1774); 120/0; Roveň; 50.50756, 15.18575; Žehrovka Brook downstrem of the Podsemínský rybník Pond; 22. 6. 2019; 257; V. Beranová, L. Beran

Pisidium amnicum (O. F. Müller, 1774); 1/0; Vyskeř; 50.52889, 15.13811; Žehrovka Brook; 22. 6. 2019; 248 ; V. Beranová, L. Beran

Pisidium amnicum (O. F. Müller, 1774); 6/0; Svitava; 50.72958, 14.64414; Svitávka Brook; 24. 8. 2017; 280 ; L. Beran; BERAN 2018b

Pisidium amnicum (O. F. Müller, 1774); 3/0; Svitava; 50.73206, 14.64011; Svitávka Brook ca 300 m downstream of a bridge; 24. 8. 2017; 280; L. Beran; BERAN 2018

Pisidium amnicum (O. F. Müller, 1774); 17/0; Kunratice u Cvikova; 50.75608, 14.67522; Svitávka Brook; 24. 8. 2017; 310; L. Beran; BERAN 2018b

Pisidium amnicum (O. F. Müller, 1774); 15/0; Heřmaničky; 50.66411, 14.61014; Ploučnice river by a bridge; 26.7. 2016; 250; L. Beran; BERAN 2016b

Pisidium amnicum (O. F. Müller, 1774); 13/0; Brenná; 50.66275, 14.63928; Svitávka Brook by a bridge; 26. 7. 2016; 255; L. Beran; BERAN 2016b

Pisidium amnicum (O. F. Müller, 1774); 3/0; Hled'sebe; 50.36747, 14.56069; Pšovka Brook near Hled'sebe; 26.8. 2017; 275; L. Beran

Pisidium amnicum (O. F. Müller, 1774); 7/0; Velenice; 50.72514, 14.65758; Svitávka Brook upstream of Velenice; 26. 8. 2017; 275; L. Beran; BERAN 2018b

Pisidium amnicum (O. F. Müller, 1774); 6/0; Hostěnice; 50.43778, 14.14831; canal of the Ohře River N of Hostěnice; 27. 5. 2017; 154; L. Beran

Pisidium amnicum (O. F. Müller, 1774); 3/0; Vsetín; 49.33056, 17.99722; canal of the Bečva River by a hospital; 28. 11. 2015; 343; L. Beran

Pisidium amnicum (O. F. Müller, 1774); 20/0; Veselí; 50.64267, 14.64703; Ploučnice River by a camp; 29. 5. 2015; 270; L. Beran; BERAN 2016b

Pisidium globulare Clessin, 1873; 8/0; Stupava (ČR); 49.09713, 17.22197; U Mísy Spring; 15. 5. 2015; 455; M. Horsák

Pisidium globulare Clessin, 1873; 40/0; Zábřeh; 49.91605, 18.07369; sedge marshes S of Zábřeh; 19. 4. 2015; 225; L. Beran

Pisidium globulare Clessin, 1873; 25/0; Zábřeh; 49.91739, 18.06717; small sedge marshes SW of Zábřeh; 19. 4. 2015; 225; L. Beran

Pisidium globulare Clessin, 1873; 30/0; Kouty; 49.91772, 18.05572; sedge marshes in meadows SE of Kouty; 19. 4. 2015; 225; L. Beran

Pisidium globulare Clessin, 1873; 62/0; Jistebník; 49.73925, 18.13544; sedge marshes N of Starý rybník Pond; 31.12. 2018; 220; J. Hlava, L. Beran

Pisidium hibernicum Westerlund, 1894; 8/0; Kláštěrec n. Orlicí; 50.12816, 16.56100; Divoká Orlice River above the town; 5. 10. 2015; 493; J. Bojková

Pisidium hibernicum Westerlund, 1894; 6/0; Milíkov; 49.75069, 12.93577; Mže River; 14. 4. 2015; 375; J. Bojková 


\begin{tabular}{|c|c|}
\hline & $\begin{array}{l}\text { Pisidium hibernicum Westerlund, 1894; 84/0; Františkov; 48.89208, 14.95016; Dračice Creek; 23. 7. 2015; 458; D. } \\
\text { Němejcová }\end{array}$ \\
\hline & $\begin{array}{l}\text { Pisidium hibernicum Westerlund, 1894; 1/0; Loužek; 48.69716, 14.47544; Malše River; 25. 10. 2015; 575; D. Ně- } \\
\text { mejcová }\end{array}$ \\
\hline & $\begin{array}{l}\text { Pisidium hibernicum Westerlund, 1894; 7/0; Sušice; 49.25180, 13.52986; Ostružná Creek; 29. 9. 2015; 468; J. Boj- } \\
\text { ková }\end{array}$ \\
\hline & $\begin{array}{l}\text { Pisidium moitessierianum Paladilhe, 1866; 20/0; Prosenice; 49.50144, 17.50494; canal of the Bečva River (Strhanec); } \\
\text { 5. 11. 2016; 219; L. Beran }\end{array}$ \\
\hline & $\begin{array}{l}\text { Pisidium moitessierianum Paladilhe, 1866; 16/0; Osek nad Bečvou; 49.50972, 17.53694; canal of the Bečva River } \\
\text { (Strhanec) by the bridge; 5. 11. 2016; 225; L. Beran }\end{array}$ \\
\hline & $\begin{array}{l}\text { Pisidium moitessierianum Paladilhe, 1866; 1/0; Libochovany; 50.56809, 14.03805; Labe River in Libochovany; } 15.9 . \\
\text { 2019; 149; V. Beranová, L. Beran }\end{array}$ \\
\hline & $\begin{array}{l}\text { Pisidium moitessierianum Paladilhe, 1866; 2/0; Vsetín; 49.33219, 17.99517; canal of the Bečva River south of the } \\
\text { railway station; 28. 11. 2015; 330; L. Beran }\end{array}$ \\
\hline & $\begin{array}{l}\text { Pisidium pseudosphaerium J. Favre, 1927; 2/0; Hradčany nad Ploučnici; 50.61578, 14.73008; N edge of a sandpit; } \\
\text { 2. 5. 2018; 270; L. Beran }\end{array}$ \\
\hline & $\begin{array}{l}\text { Pisidium pseudosphaerium J. Favre, 1927; 6/0; Lázně Bohdaneč; 50.09622, 15.68314; edge of a cove of the Bohda- } \\
\text { nečský rybník Pond; 9. 9. 2015; 218; L. Beran }\end{array}$ \\
\hline & $\begin{array}{l}\text { Pisidium pseudosphaerium J. Favre, 1927; 8/0; Jestřebí; 50.62189, 14.55786; small pool near Novozámecký rybník } \\
\text { Pond; 10. 10. 2018; 255; L. Beran }\end{array}$ \\
\hline & $\begin{array}{l}\text { Pisidium pseudosphaerium J. Favre, 1927; 14/0; Jestřebí; 50.62211, 14.55753; small pool near Novozámecký rybník } \\
\text { Pond; 10. 10. 2018; 250; L. Beran }\end{array}$ \\
\hline & $\begin{array}{l}\text { Pisidium pseudosphaerium J. Favre, 1927; 5/0; Doksy; 50.57475, 14.65522; two small pools by the Máchovo jezero } \\
\text { Pond; 17. 6. 2017; 260; L. Beran }\end{array}$ \\
\hline & $\begin{array}{l}\text { Pisidium pseudosphaerium J. Favre, 1927; 30/0; Týnec nad Labem; 50.04778, 15.40419; small pool in reeds; } 25.4 . \\
\text { 2015; 210; L. Beran }\end{array}$ \\
\hline & $\begin{array}{l}\text { Pisidium pseudosphaerium J. Favre, 1927; 5/0; Týnec nad Labem; 50.04906, 15.38475; sedge marshes in the W part } \\
\text { of the Týnecké mokřiny NR; 25. 4. 2015; 210; L. Beran }\end{array}$ \\
\hline & $\begin{array}{l}\text { Pisidium pseudosphaerium J. Favre, 1927; 10/0; Týnec nad Labem; 50.05036, 15.38286; extensive pool in the W part } \\
\text { of the Týnecké mokřiny NR; 25. 4. 2015; 210; L. Beran }\end{array}$ \\
\hline & Pisidium tenuilineatum Stelfox, 1918; 6/1; Studénka; 49.69419, 18.06986; Kotvice NR; 5. 9. 2018; 240; M. Horsák \\
\hline & $\begin{array}{l}\text { Pisidium tenuilineatum Stelfox, 1918; 2/0; Hovězí; 49.30317, 18.07883; canal of the Bečva River in a camp; } 7.10 . \\
\text { 2017; 370; L. Beran }\end{array}$ \\
\hline & $\begin{array}{l}\text { Pisidium tenuilineatum Stelfox, 1918; 3/0; Medonosy; 50.49558, 14.48867; canal of the Liběchovka Brook; } 16.8 \text {. } \\
\text { 2017; 200; L. Beran }\end{array}$ \\
\hline & $\begin{array}{l}\text { Pisidium tenuilineatum Stelfox, 1918; 3/0; Medonosy; 50.49567, 14.48881; Liběchovka Brook upstream of Medo- } \\
\text { nosy; 16. 8. 2017; 200; L. Beran }\end{array}$ \\
\hline & Pisidium tenuilineatum Stelfox, 1918; 5/0; Jestřebice; 50.45350, 14.58553; Pšovka Brook; 17. 10. 2017; 235; L. Beran \\
\hline & Pisidium tenuilineatum Stelfox, 1918; 7/0; Korytná; 48.94456, 17.68183; Lubná Brook; 19. 12. 2018; 320; P. Pařil \\
\hline & $\begin{array}{l}\text { Pisidium tenuilineatum Stelfox, 1918; 15/0; Koštany nad Turcom; 49.03050, 18.89822; Turiec River upstream the } \\
\text { road bridge; 30. 6. 2017; 415; L. Beran; BERAN \& ČEJKA } 2019\end{array}$ \\
\hline & $\begin{array}{l}\text { Planorbis carinatus Müller, 1774; 20/0; Průhonice; 49.99436, 14.56400; four artificial pools in the botanical garden } \\
\text { Chotobuz; 3. 8. 2016; 306; L. Beran }\end{array}$ \\
\hline & $\begin{array}{l}\text { Planorbis carinatus Müller, 1774; 40/0; Spálené Poříćí; 49.61269, 13.60583; Bradava Brook by a castle; 11. 10. 2018; } \\
\text { 415; L. Beran }\end{array}$ \\
\hline & $\begin{array}{l}\text { Planorbis carinatus Müller, 1774; 16/0; Spálené Poříčí; 49.61436, 13.60719; fishpond by a castle; 12. 10. 2018; 415; } \\
\text { L. Beran }\end{array}$ \\
\hline & $\begin{array}{l}\text { Planorbis carinatus Müller, 1774; 20/0; Hodonín; 48.84344, 17.14247; Stará Morava canal ca } 50 \text { m from a weir; } \\
\text { 13. 7. 2017; 150; L. Beran }\end{array}$ \\
\hline & $\begin{array}{l}\text { Planorbis carinatus Müller, 1774; 10/0; Hodonín; 48.84686, 17.13058; Stará Morava canal by a bridge; 13. 7. 2017; } \\
\text { 150; L. Beran }\end{array}$ \\
\hline
\end{tabular}


Planorbis carinatus Müller, 1774; 6/0; Hodonín; 48.84811, 17.13278; Stará Morava canal ca 500 m from a weir; 13. 7. 2017; 150; L. Beran

Planorbis carinatus Müller, 1774; 8/0; Železnice; 50.47075, 15.36967; Valcha Reservoir; 13. 10. 2019; 298; L. Beran Planorbis carinatus Müller, 1774; 50/0; Pěkná; 48.84688, 13.92419; oligotrophic oxbow of the Vltava River; 18.8. 2015; 722; M. Horsák

Planorbis carinatus Müller, 1774; 16/0; Milovice; 50.22475, 14.85647; restored pools near the Mlynařice Brook; 19. 9. 2019; 191; L. Beran

Planorbis carinatus Müller, 1774; 10/0; Trojmezí; 50.30528, 12.12495; Lužní potok Brook 100 m upstream of its inflow to the Rokytnice Brook; 21. 9. 2019; 548; J. Beran, L. Beran

Planorbis carinatus Müller, 1774; 35/0; Trojmezí; 50.30625, 12.12619; Rokytnice Brook downstream of the inflow of the Lužní potok Brook; 21. 9. 2019; 546; J. Beran, L. Beran

Planorbis carinatus Müller, 1774; 14/0; Trojmezí; 50.31244, 12.11636; Rokytnice Brook ca 2 km upstream of the boundary; 21. 9. 2019; 538; J. Beran, L. Beran

Planorbis carinatus Müller, 1774; 23/0; Podhradí nad Dyjí; 48.89992, 15.68367; Dyje River downstream of a weir; 22. 7. 2018; 355; L. Beran

Planorbis carinatus Müller, 1774; 7/0; Trojmezí; 50.31769, 12.10150; Rokytnice Brook ca $50 \mathrm{~m}$ upstream of the boundary; 24. 7. 2019; 547; J. Beran, L. Beran

Potamopyrgus antipodarum (Gray, 1843); 7/0; Dráchov; 49.22903, 14.71281; Lužnice River downstream of a weir; 14. 9. 2019; 400; L. Beran

Potamopyrgus antipodarum (Gray, 1843); 30/0; Radějov; 48.85333, 17.36589; Radějovka Brook E of Radějov; 14. 12. 2019; 253; L. Beran

Potamopyrgus antipodarum (Gray, 1843); 120/0; Radějov; 48.85350, 17.35153; Radějovka Brook on the SE edge of Radějov; 14. 12. 2019; 253; L. Beran

Potamopyrgus antipodarum (Gray, 1843); 130/0; Radějov; 48.85697, 17.37556; Radějovka Brook by a bridge; 14.12. 2019; 278; L. Beran

Potamopyrgus antipodarum (Gray, 1843); 70/0; Tvarožná Lhota; 48.86167, 17.39036; Radějovka Brook downstream of Lučina Reservoir; 14. 12. 2019; 295; L. Beran

Potamopyrgus antipodarum (Gray, 1843); 40/0; Pohled; 49.60164, 15.64972; Sázava Brook by a bridge; 15. 9. 2018; 425; L. Beran

Potamopyrgus antipodarum (Gray, 1843); 7/0; Chlístov; 49.62178, 15.53169; Sázava River east of Chlístov; 15.9. 2018; 405; L. Beran

Potamopyrgus antipodarum (Gray, 1843); 20/0; Kamenná Lhota; 49.62367, 15.24792; Švihov Reservoir by a church; 15. 9. 2018; 375; L. Beran

Potamopyrgus antipodarum (Gray, 1843); 17/0; Česká Skalice; 50.42522, 16.04736; Úpa River by a weir; 16.8. 2018; 285; L. Beran

Potamopyrgus antipodarum (Gray, 1843); 28/6; Skalice; 50.48857, 13.89095; České středohoří Mts., Žejdlík brook; 22. 9. 2019; 407; J. Horáčková; HorÁčKová 2019

Pseudanodonta complanata (Rossmässler, 1835); 1/0; Pardubice; 50.01950, 15.78636; Chrudimka River ca 1 km downstream of a weir; 3. 9. 2016; 220; L. Beran; BERAN 2016c

Pseudanodonta complanata (Rossmässler, 1835); 5/0; Pardubice; 50.02328, 15.78739; Chrudimka River; 3. 9. 2016; 220; L. Beran; BERAN 2016c

Pseudanodonta complanata (Rossmässler, 1835); 2/0; Pardubice; 50.02903, 15.78442; Chrudimka River; 3. 9. 2016; 220; L. Beran; BERAN 2016c

Pseudanodonta complanata (Rossmässler, 1835); 1/0; Snopoušovy; 49.62008, 13.38947; Úhlava River near village Snopoušovy; 4. 6. 2017; 340; O. Volf, L. Beran

Pseudanodonta complanata (Rossmässler, 1835); 2/0; Chřenovice; 49.70819, 15.19606; Sázava River downstream of a weir; 11. 7. 2015; 342; L. Beran; BERAN 2020b

Pseudanodonta complanata (Rossmässler, 1835); 1/0; Chřenovice; 49.71603, 15.19794; Sázava River W of Chřenovice; 11. 7. 2015; 342; L. Beran; BERAN 2020b

Pseudanodonta complanata (Rossmässler, 1835); 9/0; Sechov; 49.70711, 15.23622; Sázava River; 11. 7. 2015; 343;

L. Beran; BERAN 2020b 
Pseudanodonta complanata (Rossmässler, 1835); 2/0; Dobrovítova Lhota; 49.67147, 15.31761; Sázava River; 18.7. 2015; 355; L. Beran; Beran 2020b

Pseudanodonta complanata (Rossmässler, 1835); 1/0; Bilantova Lhota; 49.66664, 15.33400; Sázava River NE of Bilantova Lhota; 18. 7. 2015; 360; L. Beran; BERAN 2020b

Pseudanodonta complanata (Rossmässler, 1835); 1/0; Bilantova Lhota; 49.66392, 15.32822; Sázava River; 18.7. 2015; 360; L. Beran; BERAN 2020b

Pseudanodonta complanata (Rossmässler, 1835); 1/0; Smrčná; 49.65961, 15.33994; Sázava River; 18. 7. 2015; 375;

L. Beran; BERAN 2020b

Pseudanodonta complanata (Rossmässler, 1835); 12/0; Tasovice; 48.83211, 16.15117; Dyje River upsream of a bridge in Tasovice; 18. 8. 2017; 195; L. Beran

Pseudanodonta complanata (Rossmässler, 1835); 1/0; Dobřany; 49.66239, 13.29589; Radbuza River ca $200 \mathrm{~m}$ upstream of the inflow of a brook; 18. 10. 2015; 360; L. Beran

Pseudanodonta complanata (Rossmässler, 1835); 4/0; Přeštice; 49.57128, 13.33311; Úhlava River ca $100 \mathrm{~m}$ downstream of a weir; 18. 11. 2018; 349; L. Beran

Pseudanodonta complanata (Rossmässler, 1835); 1/0; Přeštice; 49.57411, 13.34494; Úhlava River downstream of a weir; 18. 11. 2018; 349; L. Beran

Pseudanodonta complanata (Rossmässler, 1835); 1/0; Chotěšov; 49.64278, 13.19889; Radbuza River downstream of a weir; 22. 4. 2018; 335; L. Beran

Pseudanodonta complanata (Rossmässler, 1835); 1/0; Chotěšov; 49.64861, 13.20700; Radbuza River upstream of a weir; 22. 4. 2018; 335; L. Beran

Pseudanodonta complanata (Rossmässler, 1835); 2/0; Klokočov; 48.80861, 22.03881; overgrown bight of the Zemplínská Šírava Reservoir; 24. 6. 2019; 114; L. Beran

Pseudanodonta complanata (Rossmässler, 1835); 1/0; Dyjákovice; 48.74622, 16.30767; Dyje River by a shelter; 24. 8. 2019; 196; L. Beran

Pseudanodonta complanata (Rossmässler, 1835); 1/0; Malé Zalužice; 48.76669, 21.99328; S edge of the Zemplínská Sírava Reservoir; 26. 6. 2019; 114; L. Beran

Pseudanodonta complanata (Rossmässler, 1835); 3/0; Lúčky; 48.77717, 22.04019; SE edge of the Zemplínská Šírava Reservoir; 26. 6. 2019; 114; L. Beran

Pseudanodonta complanata (Rossmässler, 1835); 1/0; Hradiště; 49.71303, 13.39786; Úhlava River; 29. 11. 2015; 305; L. Beran

Pseudanodonta complanata (Rossmässler, 1835); 4/0; Plzeň; 49.71603, 13.40031; Úhlava River ca 1 km upstream of its inflow into the Radbuza River; 29. 11. 2015; 304; L. Beran

Pupilla alpicola (Charpentier, 1837); 0/1; Holany; 50.62108, 14.45719; sedge marshes on the bank of the Dolanský rybník Pond; 7. 10. 2016; 290; L. Beran; BERAN 2017a

Pyramidula saxatilis (Hartmann, 1842); 5/0; Horný Jelenec; 48.86427, 19.14786; small creek canyon with a waterfall above the village; 26. 10. 2019; 650; M. Horsák, V. Horsáková

Radix ampla (Hartmann, 1821); 12/0; Socovce; 48.95344, 18.86172; Turiec River by a bridge; 28. 6. 2019; 440; L. Beran

Radix ampla (Hartmann, 1821); 18/0; Košt'any nad Turcom; 49.03050, 18.89822; Turiec River upstream of a bridge; 30. 6. 2017; 405; L. Beran; BERAN \& ČEJKA 2019

Sinanodonta woodiana (Lea, 1834); 1/0; Mikulov; 48.80997, 16.65800; querry SE of Mikulov; 1. 5. 2015; 242; L. Beran

Sinanodonta woodiana (Lea, 1834); 3/0; Kostice; 48.73231, 17.01789; Morava River ca 400 m downstream of a weir; 3. 8. 2019; 156; K. Beran, L. Beran

Sinanodonta woodiana (Lea, 1834); 16/0; Kostice; 48.73308, 17.01703; oxbow of the Morava River SE of the village; 3. 8. 2019; 156; K. Beran, L. Beran

Sinanodonta woodiana (Lea, 1834); 17/0; Kostice; 48.73667, 17.00344; canal SE of the village; 3. 8. 2019; 156; K. Beran, L. Beran

Sinanodonta woodiana (Lea, 1834); 1/0; Krasoňov; 49.49217, 15.38495; Sýkora Pond; 4. 6. 2016; 540; L. Beran

Sinanodonta woodiana (Lea, 1834); 4/0; Týnec; 48.76831, 17.03539; Kopanice Canal E of the town; 4. 8. 2019; 157;

K. Beran, L. Beran 
Sinanodonta woodiana (Lea, 1834); 3/0; Týnec; 48.76861, 17.03028; canal E of the town; 4. 8. 2019; 157; K. Beran, L. Beran

Sinanodonta woodiana (Lea, 1834); 4/0; Košatka; 49.73350, 18.14750; Odra River near the village; 5. 5. 2018; 225; J. Kašinský, L. Beran

Sinanodonta woodiana (Lea, 1834); 30/0; Lanžhot; 48.71753, 17.01153; Morava River E of the town; 5. 10. 2019; 157; K. Beran, L. Beran

Sinanodonta woodiana (Lea, 1834); 70/0; Týnec; 48.75383, 17.03986; Morava River E of the town; 5. 10. 2019; 158;

K. Beran, L. Beran

Sinanodonta woodiana (Lea, 1834); 60/0; Moravská Nová Ves; 48.77933, 17.06914; Morava River E of the village; 5. 10. 2019; 158; K. Beran, L. Beran

Sinanodonta woodiana (Lea, 1834); 1/0; Telč; 49.18972, 15.45067; Nadýmák Pond in the town; 10. 7. 2018; 510; anonymous, L. Beran

Sinanodonta woodiana (Lea, 1834); 4/0; Oslov; 49.40620, 14.18300; junction of the Otava and Lomnice Rivers; 12. 11. 2019; 350; V. Hrdlička

Sinanodonta woodiana (Lea, 1834); 0; Oslov; 49.40619, 14.18300; Orlík Reservoir at the confluence of the Otava and Lomnice Rivers; 12. 11. 2019; 345; V. Hrdlička

Sinanodonta woodiana (Lea, 1834); 3/0; Hodonín; 48.84231, 17.14200; Morava River downstream of a weir; 13.7. 2017; 150; L. Beran

Sinanodonta woodiana (Lea, 1834); 2/0; Hodonín; 48.84294, 17.14397; Morava River upstream of a weir; 13.7. 2017; 150; L. Beran

Sinanodonta woodiana (Lea, 1834); 5/0; Hodonín; 48.84344, 17.14247; Stará Morava Canal ca 50 m downstream of a weir; 13. 7. 2017; 150; L. Beran

Sinanodonta woodiana (Lea, 1834); 8/0; Hodonín; 48.84686, 17.13058; Stará Morava Canal by a bridge; 13. 7. 2017; 150; L. Beran

Sinanodonta woodiana (Lea, 1834); 3/0; Hodonín; 48.84811, 17.13281; Stará Morava Canal ca 500 m downstream of a weir; 13. 7. 2017; 150; L. Beran

Sinanodonta woodiana (Lea, 1834); 14/0; Moravská Nová Ves; 48.79536, 17.03675; Kyjovka River by a bridge near Moravská Nová Ves; 20. 8. 2017; 190; L. Beran

Sinanodonta woodiana (Lea, 1834); 2/0; Moravská Nová Ves; 48.79972, 17.04403; Kyjovka River near the village; 20. 8. 2017; 190; L. Beran

Sinanodonta woodiana (Lea, 1834); 10/0; Moravská Nová Ves; 48.80486, 17.05147; Kyjovka River; 20. 8. 2017; 190; L. Beran

Sinanodonta woodiana (Lea, 1834); 3/0; Mikulčice; 48.80644, 17.05342; Kyjovka River near the town; 20. 8. 2017; 190; L. Beran

Sinanodonta woodiana (Lea, 1834); 4/0; Mikulčice; 48.80961, 17.05728; Kyjovka River by a bridge near the town; 20. 8. 2017; 190; L. Beran

Sinanodonta woodiana (Lea, 1834); 4/0; Košatka; 49.73419, 18.14997; Odra River; 22. 9. 2018; 225; L. Beran

Sinanodonta woodiana (Lea, 1834); 22/0; Strážnice; 48.91083, 17.31092; Velička River by a bridge; 23. 11. 2019; 177; L. Beran

Sinanodonta woodiana (Lea, 1834); 3/0; Michalovce; 48.77780, 21.95397; W edge of the Zemplínská Śírava Reservoir; 25. 6. 2019; 114; L. Beran; BERAN 2020a

Sinanodonta woodiana (Lea, 1834); 10/0; Vinné; 48.78878, 21.94653; Zemplínská Š́rava Reservoir at the inflow of the Síranský kanál Canal; 25. 6. 2019; 114; L. Beran; Beran 2020a

Sinanodonta woodiana (Lea, 1834); 10/0; Budínek; 49.75908, 14.18347; Pařezitý NM; 25. 10. 2019; 372; K. Čulík, J. Hlaváč

Sinanodonta woodiana (Lea, 1834); 2/0; Kaluža; 48.79878, 22.00078; NW edge of the Zemplínská Šírava Reservoir; 27. 6. 2019; 114; L. Beran; BERAN 2020a

Sinanodonta woodiana (Lea, 1834); 0/2; Hluboká nad Vltavou; 49.04163, 14.41650; SW edge of the Munický Pond; 27. 12. 2019; 390; L. Dvořák

Sinanodonta woodiana (Lea, 1834); 2/0; Lhotka; 49.75379, 14.14612; Př́ivaží Pond; 28. 10. 2019; 396; K. Čulík, J. Hlaváč 
Sinanodonta woodiana (Lea, 1834); 3/0; Troubky; 49.41331, 17.33358; Malá Bečva Canal by a bridge near a sandpit; 30. 11. 2019; 196; L. Beran

Sinanodonta woodiana (Lea, 1834); 90/0; Troubky; 49.42944, 17.33861; Malá Bečva Canal by a bridge of a road Tovačov - Troubky; 30. 11. 2019; 196; L. Beran

Sinanodonta woodiana (Lea, 1834); 2/0; Troubky; 49.43133, 17.33328; Bečva River downstream of a weir; 30.11. 2019; 196; L. Beran

Sphaerium nucleus (Studer, 1820); 3/0; Děhylov; 49.86089, 18.19728; wetland by the Štěpán Pond; 1. 6. 2017; 210; L. Beran

Sphaerium nucleus (Studer, 1820); 15/0; Hradčany nad Ploučnicí; 50.61772, 14.71083; NE edge of Hradčanský rybník Pond; 1. 11. 2018; 268; L. Beran

Sphaerium nucleus (Studer, 1820); 20/0; Neratov; 50.08633, 15.63761; alderwoods by the Rozhrna Pond; 2. 6. 2018; 222; L. Beran

Sphaerium nucleus (Studer, 1820); 5/0; Březina; 50.54397, 15.05950; SE part of the Žabakor Pond; 5. 5. 2019; 237; V. Beranová, L. Beran

Sphaerium nucleus (Studer, 1820); 28/0; Žd'ár; 50.54517, 15.06108; alder carr by the Žabakor Pond; 5. 5. 2019; 237; V. Beranová, L. Beran

Sphaerium nucleus (Studer, 1820); 40/0; Březina; 50.54539, 15.05567; reeds by the S bank of the Žabakor Pond; 5 . 5. 2019; 237; V. Beranová, L. Beran

Sphaerium nucleus (Studer, 1820); 22/0; Březina; 50.54544, 15.05153; S bank of the Žabakor Pond; 5. 5. 2019; 237; V. Beranová, L. Beran

Sphaerium nucleus (Studer, 1820); 8/0; Žd'ár; 50.54586, 15.06256; alder carr by the E bank of the Žabakor Pond; 5. 5. 2019; 237; V. Beranová, L. Beran

Sphaerium nucleus (Studer, 1820); 40/0; Doubrava; 50.55039, 15.05897; wetlands by the N bank of the Žabakor Pond; 5. 5. 2019; 237; V. Beranová, L. Beran

Sphaerium nucleus (Studer, 1820); 2/0; Tvrdonice; 48.74944, 17.00278; N part of the extensive oxbow in the Stibůrkovská jezera NM; 6. 5. 2017; 156; L. Beran

Sphaerium nucleus (Studer, 1820); 10/0; Stvolínky; 50.62964, 14.43972; reeds in the NE part of the Dolanský rybník Pond; 7. 9. 2016; 270; L. Beran; BERAN 2017a

Sphaerium nucleus (Studer, 1820); 2/0; Litice; 50.62108, 14.45719; sedge marshes by the Dolanský rybník Pond; 7. 10. 2016; 305; L. Beran; BERAN 2017a

Sphaerium nucleus (Studer, 1820); 8/0; Brenná; 50.66122, 14.63381; wetland by the Svitávka River; 14. 4. 2016; 280; L. Beran

Sphaerium nucleus (Studer, 1820); 1/0; Tvrdonice; 48.74833, 17.00250; shallow pool in the Stibůrkovská jezera NM; 16. 3. 2019; 156; L. Beran

Sphaerium nucleus (Studer, 1820); 2/0; Tvrdonice; 48.74944, 17.00278; N part of the extensive oxbow in the Stiburrkovská jezera NM; 16. 3. 2019; 156; L. Beran

Sphaerium nucleus (Studer, 1820); 10/0; Tvrdonice; 48.75075, 17.00278; pool SE of Tvrdonice; 16. 5. 2015; 156; L. Beran

Sphaerium nucleus (Studer, 1820); 3/0; Doksy; 50.57778, 14.66222; wetland in the E part of the Swamp NNM; 16.6 . 2016; 266; L. Beran

Sphaerium nucleus (Studer, 1820); 10/0; Doksy; 50.57475, 14.65522; two pools by the Máchovo jezero Pond; 17.6 . 2017; 260; L. Beran

Sphaerium nucleus (Studer, 1820); 2/0; Dolní Benešov; 49.91308, 18.10097; pool by the Nezmar Pond; 18. 4. 2015; 224; L. Beran

Sphaerium nucleus (Studer, 1820); 20/0; Pěkná; 48.84688, 13.92419; oligotrophic oxbow of the Vltava River; 18.8. 2015; 722; M. Horsák

Sphaerium nucleus (Studer, 1820); 10/0; Zábřeh; 49.91694, 18.07414; sedge marshes in the Zábřežské a Koutské louky NR; 19. 4. 2015; 225; L. Beran

Sphaerium nucleus (Studer, 1820); 4/0; Zábřeh; 49.91761, 18.08111; ditch by the Zábřežské a Koutské louky NR; 19. 4. 2015; 225; L. Beran

Sphaerium nucleus (Studer, 1820); 13/0; Zábřeh; 49.91767, 18.05967; small pool by the Štěpánka Brook; 19. 4. 2015; 225; L. Beran 
Sphaerium nucleus (Studer, 1820); 40/0; Zábřeh; 49.91806, 18.07475; ditch in the E part of the Zábřežské a Koutské louky NR; 19. 4. 2015; 225; L. Beran

Sphaerium nucleus (Studer, 1820); 5/0; Stvolínky; 50.62642, 14.43969; NW part of the Dolanský rybník Pond; 19. 5. 2015; 265; L. Beran; BERAN 2017

Sphaerium nucleus (Studer, 1820); 2/0; Stvolínky; 50.62836, 14.44181; NE part of the Dolanský rybník Pond; 19.5. 2015; 265; L. Beran; BERAN 2017

Sphaerium nucleus (Studer, 1820); 5/0; Lipník nad Bečvou; 49.52222, 17.59806; overgrown oxbow in Škrabalka NR; 20. 8. 2016; 227; L. Beran

Sphaerium nucleus (Studer, 1820); 2/0; Košatka; 49.74233, 18.16042; pool by the S bank of the Oderský rybník Pond; 22. 9. 2018; 225; L. Beran

Sphaerium nucleus (Studer, 1820); 40/0; Košatka; 49.74278, 18.16264; pool by the Odra River; 22. 9. 2018; 225 ; L. Beran

Sphaerium nucleus (Studer, 1820); 4/0; Košatka; 49.74311, 18.16275; pool by the S bank of the Prosňák Pond; 22. 9. 2018; 225; L. Beran

Sphaerium nucleus (Studer, 1820); 3/0; Libice nad Cidlinou; 50.11964, 15.16291; pool Malý Přerov in the Libický luh NNR; 24. 3. 2017; 190; L. Beran

Sphaerium nucleus (Studer, 1820); 8/0; Týnec nad Labem; 50.04778, 15.40419; small pool E of the Týnecké mokřiny NR; 25. 4. 2015; 210; L. Beran

Sphaerium nucleus (Studer, 1820); 10/0; Stvolínky; 50.62056, 14.44742; S part of the Dolanský rybník Pond; 25.5. 2015; 265; L. Beran; BERAN 2017a

Sphaerium nucleus (Studer, 1820); 3/0; Chot'ovice; 50.14239, 15.35150; sedge marshes in the E part of the Žehuňský rybník NNR; 25. 7. 2019; 204; V. Beranová, L. Beran

Sphaerium nucleus (Studer, 1820); 22/0; Obora; 50.55278, 14.66806; alder carr by the Poselský rybník Pond; 26.11. 2019; 288; L. Beran

Sphaerium nucleus (Studer, 1820); 18/0; Doksy; 50.57528, 14.66456; small pool by the Máchovo jezero Pond; 27. 8. 2019; 255; L. Beran

Sphaerium nucleus (Studer, 1820); 2/0; Bartošovice; 49.66839, 18.01186; wetlands near the Odra River; 31. 12. 2018; 247; L. Beran

Sphaerium nucleus (Studer, 1820); 34/0; Jistebník; 49.73272, 18.13272; overgrown canal S of the Sítinový rybník Pond; 31. 12. 2018; 220; L. Beran

Sphaerium nucleus (Studer, 1820); 21/0; Jistebník; 49.73353, 18.12344; wetland SW of the mill; 31. 12. 2018; 220; L. Beran

Sphaerium nucleus (Studer, 1820); 20/0; Jistebník; 49.74017, 18.14292; flooded reeds in the Rákosina NR; 31.12. 2018; 220; L. Beran

Sphaerium rivicola (Lamarck, 1818); 14/0; Čerčany; 49.84642, 14.69150; Sázava River; 1. 12. 2018; 270; L. Beran Sphaerium rivicola (Lamarck, 1818); 8/0; Čerčany; 49.85500, 14.69944; Sázava River downstream of a weir; 1.12. 2018; 308; L. Beran

Sphaerium rivicola (Lamarck, 1818); 4/0; Hostěnice; 50.43747, 14.16333; Ohře River; 3. 6. 2018; 170; L. Beran Sphaerium rivicola (Lamarck, 1818); 2/0; Doksany; 50.44653, 14.16183; Ohře River; 3. 6. 2018; 156; L. Beran

Sphaerium rivicola (Lamarck, 1818); 100/0; Hostěnice; 50.43411, 14.15011; canal of the Ohře River; 4. 6. 2017; 170; L. Beran

Sphaerium rivicola (Lamarck, 1818); 15/0; Hostěnice; 50.43789, 14.14830; canal of the Ohře River; 4. 6. 2017; 170; L. Beran

Sphaerium rivicola (Lamarck, 1818); 30/0; Bohušovice nad Ohř́́; 50.49389, 14.15806; Ohře River by a bridge in the village; 4. 8. 2018; 150; L. Beran

Sphaerium rivicola (Lamarck, 1818); 4/0; Bohušovice nad Ohří; 50.49389, 14.15806; Ohře River by a bridge in the village; 10. 8. 2015; 150; L. Beran

Sphaerium rivicola (Lamarck, 1818); 2/0; Budyně nad Ohř́í; 50.40944, 14.11611; Ohře River by a bridge; 23. 7. 2015; 161; L. Beran

Sphaerium rivicola (Lamarck, 1818); 3/0; Chrást nad Sázavou; 49.83894, 14.57525; Sázava River downstream of a weir; 26. 7. 2015; 250; L. Beran; BERAN 2020b 
Stagnicola turricula (Held, 1836); 13/0; Oudoleň; 49.64828, 15.75253; Oudoleňský potok Brook; 1. 5. 2018; 510; L. Beran; BERAN 2020b

Subulina striatella (Rang, 1831); 3/0; Bratislava; 48.14699, 17.07249; tropical greenhouse in the Botanical garden; 5. 1. 2019; 147; J. Čapka

Tandonia kusceri (Wagner, 1931); 1; Bratislava; 48.14678, 17.06462; Karlova Ves, Danube branch; 17. 7. 2015; 142; T. Čejka

Tandonia kusceri (Wagner, 1931); 5; Bratislava; 48.20708, 16.97594; Devínska Nová Ves district, cemetery; 13. 9. 2017; 158; T. Čejka

Tandonia kusceri (Wagner, 1931); 3; Bratislava; 48.15125, 17.03143; Karlova Ves, Agapé horticultural centre; 2.7. 2018; 141; T. Čejka

Tandonia kusceri (Wagner, 1931); 2; Bratislava; 48.17276, 17.06645; Karlova Ves, Slovak Academy od Sciences complex, near the building of the Botanical Institute; 17. 7. 2018; 189; T. Čejka

Tandonia kusceri (Wagner, 1931); 15; Bratislava; 48.14170, 17.09408; Žižkova Street; 20. 7. 2018; 148; T. Čejka

Tandonia kusceri (Wagner, 1931); 2; Bratislava; 48.19224, 16.97827; Devín district, garden under the Weitov lom Quarry; 23. 7. 2018; 176; T. Čejka

Tandonia kusceri (Wagner, 1931); 2; Banská Štiavnica; 48.45615, 18.89947; Katova Street No. 11; 28. 8. 2018; 590; T. Čejka

Tandonia kusceri (Wagner, 1931); 2; Bratislava; 48.04628, 17.15209; Rusovce, railway road; 28. 2. 2019; 132; T. Čejka

Tandonia kusceri (Wagner, 1931); 2; Bratislava; 48.14649, 17.07335; Karlova Ves, Botanical garden; 15. 4. 2019; 144; T. Čejka

Tandonia kusceri (Wagner, 1931); 5; Stupava; 48.27417, 17.02928; Stupava, Marcheggská Street; 4. 5. 2019; 175; T. Čejka

Tandonia kusceri (Wagner, 1931); 3; Svätý Jur; 48.26121, 17.19544; Biely Kameň castle ruin; 15. 9. 2019; $298 ;$ T. Čejka

Tandonia kusceri (Wagner, 1931); 2; Bratislava; 48.10068, 17.12475; Petržalka, Pieskovisko Sandpit; 25. 11. 2019; 140; T. Čejka

Tandonia kusceri (Wagner, 1931); 7; Bratislava; 48.13013, 17.11860; Petržalka, Černyševského Street; 15. 4. 2015; 136; T. Čejka

Tandonia kusceri (Wagner, 1931); 18; Bratislava; 48.17360, 17.14680; Nové Mesto city district; 15. 6. 2018; 145; T. Čejka, J. Čačaný

Unio crassus Philipsson, 1788; 1/0; Vestec; 49.96811, 15.81378; Chrudimka River; 1. 10. 2016; 242; L. Beran; BERAN $2016 \mathrm{c}$

Unio crassus Philipsson, 1788; 1/0; Tuněchody; 49.96978, 15.83242; Chrudimka River; 1. 10. 2016; 239; L. Beran; BERAN 2016c

Unio crassus Philipsson, 1788; 1/0; Úhřetická Lhota; 49.98711, 15.86014; Chrudimka River 500 m upstream of confluence with Novohradka River; 1. 10. 2016; 235; L. Beran; BERAN 2016c

Unio crassus Philipsson, 1788; 2/0; Hostovice; 49.99755, 15.86017; Chrudimka River; 1. 10. 2016; 235; L. Beran; BERAN 2016c

Unio crassus Philipsson, 1788; 4/0; Senorady; 49.13586, 16.22619; Oslava River ca $800 \mathrm{~m}$ from the inflow of the Chvojnice River; 1. 10. 2017; 275; L. Beran; BERAN 2019c

Unio crassus Philipsson, 1788; 2/0; Senorady; 49.13722, 16.22861; Oslava River upstream of the infow of the Chvojnice River; 1. 10. 2017; 325; L. Beran; BERAN 2019c

Unio crassus Philipsson, 1788; 5/0; Krasíkovice; 49.46872, 15.22364; Hejlovka Brook by a bridge; 3. 6. 2017; 470; L. Beran; BERAN 2020b

Unio crassus Philipsson, 1788; 1/0; Kojčice; 49.48217, 15.24858; Hejlovka by the Prokopův Mlýn Mill; 3. 6. 2017; 460; L. Beran; BERAN 2020b

Unio crassus Philipsson, 1788; 0/1; Sázavka; 49.73592, 15.39469; Sázavka Brook; 3. 6. 2017; 440; L. Beran; BERAN $2020 \mathrm{~b}$

Unio crassus Philipsson, 1788; 3/0; Čakovice; 49.46011, 15.17428; Hejlovka Brook near the Čakovický Mlýn Mill; 4. 6. 2017; 490; L. Beran; BERAN 2020b 
Unio crassus Philipsson, 1788; 1/0; Čakovice; 49.47208, 15.18481; Hejlovka Brook by a bridge of the road Pelhřimov - Červená Řečice; 4. 6. 2017; 490; L. Beran; Beran 2020b

Unio crassus Philipsson, 1788; 1/0; Žižín; 50.01364, 15.84939; Chrudimka River; 4. 9. 2016; 230; L. Beran; BERAN $2016 \mathrm{c}$

Unio crassus Philipsson, 1788; 4/0; Úhřetická Lhota; 49.98805, 15.86408; Novohradka River ca 100 m upstream of the confluence with the Chrudimka River; 9. 5. 2015; 240; L. Beran; BERAN 2018a

Unio crassus Philipsson, 1788; 2/0; Úhřetická Lhota; 49.98853, 15.86297; Chrudimka River upstream of the confluence with the Novohradka River; 9. 5. 2015; 240; L. Beran; BERAN 2016c

Unio crassus Philipsson, 1788; 7/0; Úhřetická Lhota; 49.99286, 15.86281; Chrudimka River; 9. 5. 2015; 240; L. Beran; BERAN 2016c

Unio crassus Philipsson, 1788; 1/0; Miletín; 49.56981, 15.24025; Želivka River; 12. 7. 2015; 385; L. Beran; BerAN 2020b

Unio crassus Philipsson, 1788; 1/0; Slavíć; 49.52778, 17.66225; Bečva River; 12. 8. 2019; 235; L. Beran

Unio crassus Philipsson, 1788; 6/0; Dubovice; 49.43903, 15.16544; Hejlovka Brook NW of Dubovice; 16. 9. 2017; 520; L. Beran; BERAN 2020b

Unio crassus Philipsson, 1788; 1/0; Nová Ves; 49.11814, 16.30567; Oslava River near Nová Ves; 18. 8. 2018; 228;

L. Beran; BERAN 2019c

Unio crassus Philipsson, 1788; 3/0; Oslavany; 49.12247, 16.32353; Oslava River near Oslavany; 18. 8. 2018; 226;

L. Beran; BERAN 2019c

Unio crassus Philipsson, 1788; 7/0; Litoměřice; 50.52858, 14.13444; confluence of rivers Labe and Ohře River; 20. 10. 2019; 148; L. Beran, J. Beran

Unio crassus Philipsson, 1788; numerous live individuals; Močovice - Čáslav - Církvice - Jakub; 49.9106, 15.3532 49.9506, 15.3313; Klejnárka, several places in the stretch from Močovice through Čáslav and Církvice to Jakub; 2015-2016; 238-214; O. Korábek

Unio crassus Philipsson, 1788; 26/0; Kylešovice; 49.90950, 17.92406; canal of the Moravice River; 26. 10. 2019; 248; L. Beran

Unio crassus Philipsson, 1788; 2/0; Kylešovice; 49.91208, 17.91894; Moravice River; 26. 10. 2019; 248; L. Beran

Unio crassus Philipsson, 1788; 5/0; Kylešovice; 49.91378, 17.93536; canal of the Moravice River; 26. 10. 2019; 248;

L. Beran

Unio crassus Philipsson, 1788; 16/0; Kylešovice; 49.91792, 17.94250; canal of the Moravice River; 26. 10. 2019; 248; L. Beran

Unio crassus Philipsson, 1788; 1/0; Vejvanovice; 49.97361, 15.88636; Novohradka River by a bridge SE of the village; 29. 8. 2017; 238; L. Beran; BERAN 2018a

Unio crassus Philipsson, 1788; 1/0; Dvakačovice; 49.97553, 15.90455; Novohradka River E of the village; 29. 8. 2017; 238; L. Beran; Beran 2018a

Unio crassus Philipsson, 1788; 1/0; Úhřetice; 49.97875, 15.87372; Novohradka River by a bridge of the road Úhřetice - Dvakačovice; 29. 8. 2017; 234; L. Beran; BERAN 2018a

Unio crassus Philipsson, 1788; 3/0; Úhřetice; 49.98755, 15.86625; Novohradka River; 29. 8. 2017; 230; L. Beran; BERAN 2018a

Unio crassus Philipsson, 1788; 3/0; Hradiště; 49.71303, 13.39786; Úhlava River; 29. 11. 2015; 305; L. Beran

Unio crassus Philipsson, 1788; 3/0; Plzeň; 49.71603, 13.40031; Úhlava River $1 \mathrm{~km}$ upstream of its inflow into the Radbuza River; 29. 11. 2015; 304; L. Beran

Unio crassus Philipsson, 1788; 2/0; Kokšín; 49.46297, 13.28650; Točnický potok Brook in the village; 30. 8. 2016; 378; D. Fischer, L. Beran

Unio crassus Philipsson, 1788; 24/0; Jíno; 49.51000, 13.31031; Vlčí potok Brook in the village; 30. 8. 2016; 357;

D. Fischer, L. Beran

Unio crassus Philipsson, 1788; 1/0; Březovice; 49.95575, 15.96539; Novohradka River by a bridge in the village;

30. 8. 2017; 250; L. Beran; BERAN 2018a

Vallonia enniensis Gredler, 1856; 1/4; Vacenovice; 48.95186, 17.17927; Jezero NR, fen meadow behind the northeastern edge of the village ;23. 6. 2015; 190; T. Němec

Vertigo angustior Jeffreys, 1830; 2/2; Poutnov; 50.02658, 12.85083; spring fen $1 \mathrm{~km}$ SE from the village, near to the Jewish cemetery, below Tisovský Hill; 10. 8. 2017; 670; M. Horsák; HonsákOvá \& HoRsáK 2018 
Vertigo angustior Jeffreys, 1830; 10/0; Mutišov; 49.00258, 15.38222; fen meadow by the village; 20. 8. 2019; 500; M. Horsák

Vertigo geyeri Lindholm, 1925; 15/0; Soběšice; 49.18937, 13.65469; Ve Volešku, moisty grassland in the Novosedelský potok floodplain; 8. 9. 2014; 650; J. Hlaváč

Vertigo geyeri Lindholm, 1925; 24/91; Poutnov; 50.02658, 12.85083; spring fen $1 \mathrm{~km}$ SE from the village, near to the Jewish cemetery, below Tisovský Hill; 10. 8. 2017; 670; M. Horsák; Horsáková \& Horsák 2018

Vertigo geyeri Lindholm, 1925; 5/0; Albrechtice; 49.20948, 13.57109; Pastviště u Fínů NNM; 16. 7. 2013; 625; J. Hlaváč

Vertigo lilljeborgi (Westerlund, 1871); 1/0; Chomutov; 50.46766, 13.37988; Domovina; 15. 11. 2017; 387; P. Krásenský

Vertigo lilljeborgi (Westerlund, 1871); 4/0; Pěkná; 48.85027, 13.92016; Vltava River alluvium; 18. 8. 2015; 721; M. Horsák

Vertigo lilljeborgi (Westerlund, 1871); 3/3; Liboc; 50.27422, 12.47728; peat bog by the Čirý potok Brook; 8. 11. 2019; 584; V. Melichar, L. Beran

Vertigo moulinsiana (Dupuy, 1849); 5/0; Heršpice; 49.11379, 16.93172; Jalový dvůr NM, 1.6 km SE of the village, Jalovák Pond; 3. 7. 2018; 241; M. Horsák a kol.

Vertigo moulinsiana (Dupuy, 1849); 10/0; Rašovice; 49.12690, 16.93450; Rašovický zlom - Chobot NR, 1 km NW of the village; 3. 7. 2018; 225; M. Horsák a kol.

Vertigo moulinsiana (Dupuy, 1849); 4/0; Loučeň; 50.29125, 15.00769; fen on the bank of the Knížecí rybník Pond; 6. 10. 2015; 255; L. Beran

Vertigo moulinsiana (Dupuy, 1849); 3/0; Loučeň; 50.29147, 15.00583; calcareous fen downstream of the Knížecí rybník Pond; 6. 10. 2015; 255; L. Beran

Vertigo moulinsiana (Dupuy, 1849); 3/0; Loučeň; 50.29283, 15.00244; sedge marshes in the former pond Lutovník; 6. 10. 2015; 255; L. Beran

Vertigo moulinsiana (Dupuy, 1849); 15/0; Struhy; 50.29258, 14.92739; reeds on the bank of the pond in Struhy; 11. 10. 2016; 205; L. Beran

Vertigo moulinsiana (Dupuy, 1849); 6/3; Jablonica; 48.59632, 17.45120; Zrubárka NM; 12. 6. 2017; 244; T. Čejka, J. Čačaný

Vertigo moulinsiana (Dupuy, 1849); 30; Závod; 48.53105, 17.01403; East of the Abrod NNR, right bank of the Porec Stream; 16. 8. 2016; 168; J. Čačaný; ČAČANÝ 2020

Vertigo moulinsiana (Dupuy, 1849); 50/0; Třebechovice pod Orebem; 50.18408, 16.04255; U Houkvice NR, Malá Houkvice Pond; 20. 8. 2018; 250; M. Horsák

Viviparus acerosus (Bourguignat, 1862); 120/0; Kamenná Lhota; 49.62367, 15.24792; Švihov Reservoir by a church of former Zahrádka Village; 2. 8. 2015; 375; L. Beran; BERAN et al. 2019

Viviparus acerosus (Bourguignat, 1862); 60/0; Krasoňov; 49.48775, 15.39786; Tuksa Pond; 4. 6. 2016; 540; L. Beran; BERAN et al. 2019

Viviparus acerosus (Bourguignat, 1862); 30/0; Krasoňov; 49.49226, 15.38502; Sýkora Pond; 4. 6. 2016; 540; L. Beran; BERAN et al. 2019

Viviparus acerosus (Bourguignat, 1862); 3/300; Bartošovice; 49.67738, 18.02913; Horní Bartošovický Pond; 5.9. 2018; 245; M. Horsák; BERAN et al. 2019

Viviparus acerosus (Bourguignat, 1862); 130/0; Hodonín; 48.84344, 17.14247; Stará Morava canal ca 50 m downstream of a weir; 13. 7. 2017; 150; L. Beran

Viviparus acerosus (Bourguignat, 1862); 30/0; Hodonín; 48.84686, 17.13058; Stará Morava canal by a bridge; 13.7. 2017; 150; L. Beran

Viviparus acerosus (Bourguignat, 1862); 120/0; Hodonín; 48.84811, 17.13281; Stará Morava canal ca 500 m downstream of a weir; 13. 7. 2017; 150; L. Beran

Viviparus acerosus (Bourguignat, 1862); 80/0; Kamenná Lhota; 49.62367, 15.24792; Švihov Reservoir by a church of former Zahrádka Village; 15. 9. 2018; 375; L. Beran; BERAN et al. 2019

Viviparus acerosus (Bourguignat, 1862); 26/0; Hojanovice; 49.61431, 15.25278; bank of the Švihov Reservoir NE of the village; 25. 7. 2019; 392; L. Beran; BERAN et al. 2019

Zebrina detrita (Müller, 1774); 0/3; Praha - Butovice; 50.03988, 14.35439; Prokopské údolí NR, rocky steppe grassland in the area of the former medieval settlement Butovické hradiště; 27. 4. 2019; 295; M. Šafka, J. Hlaváč 


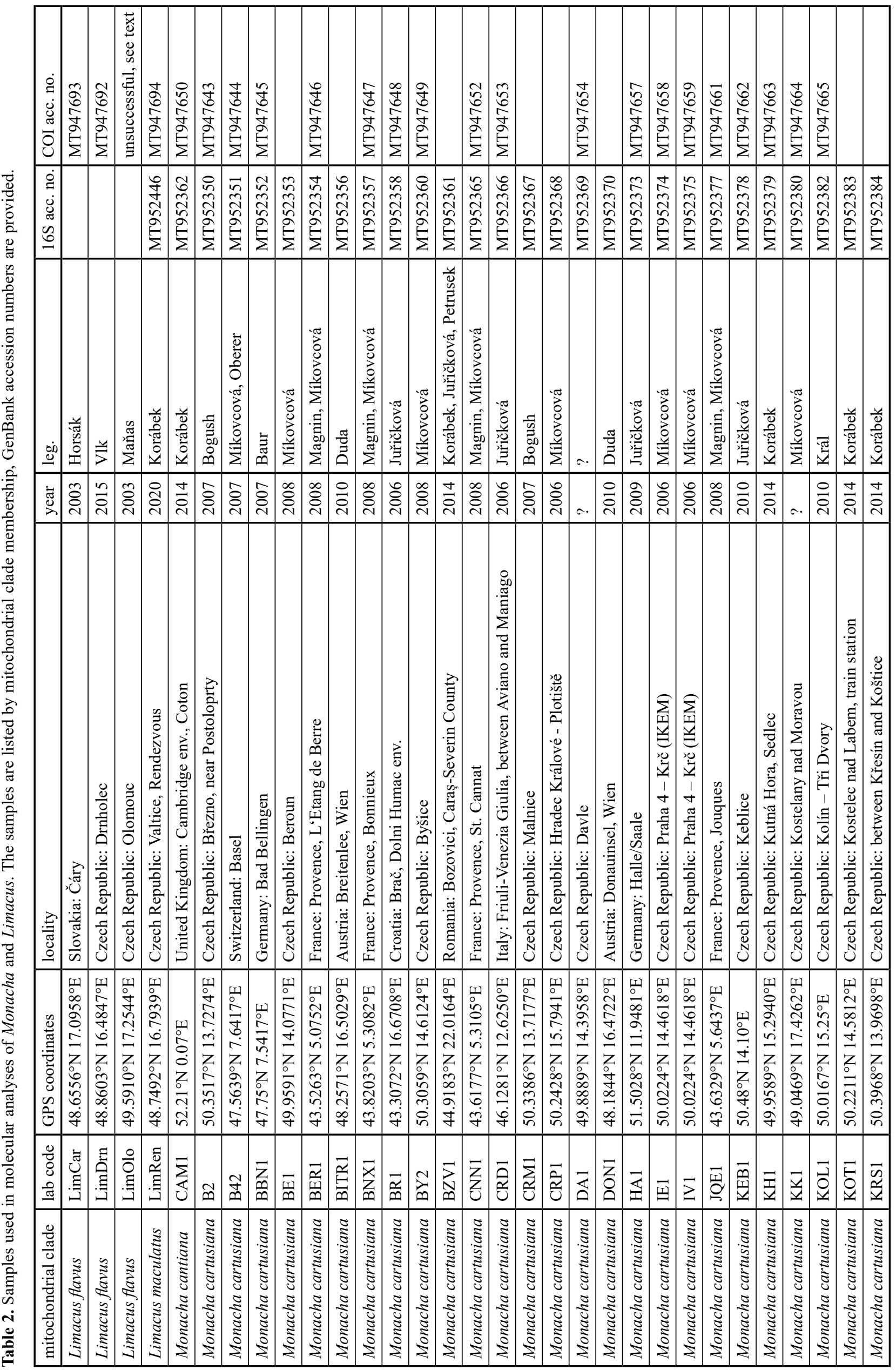




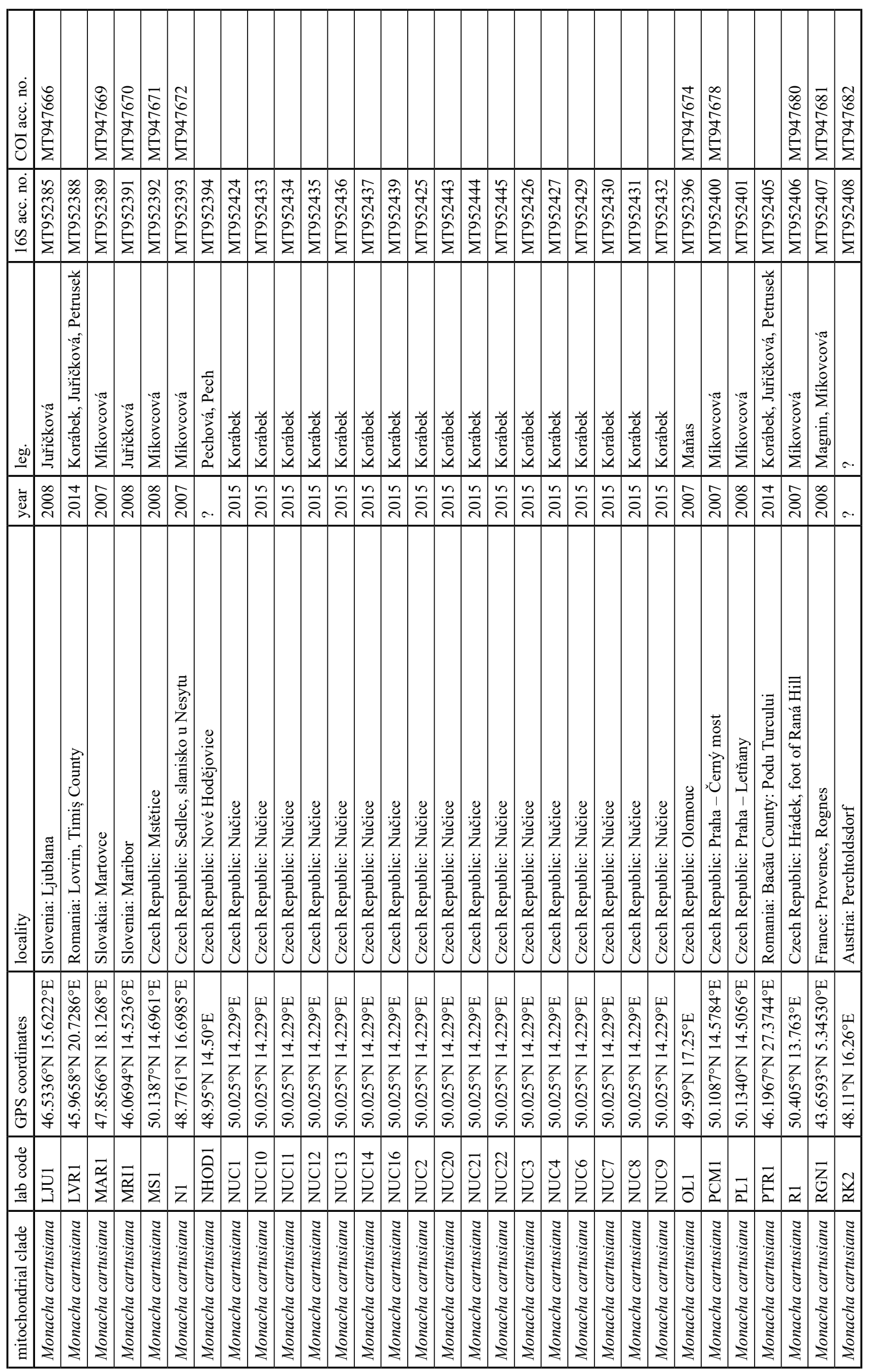




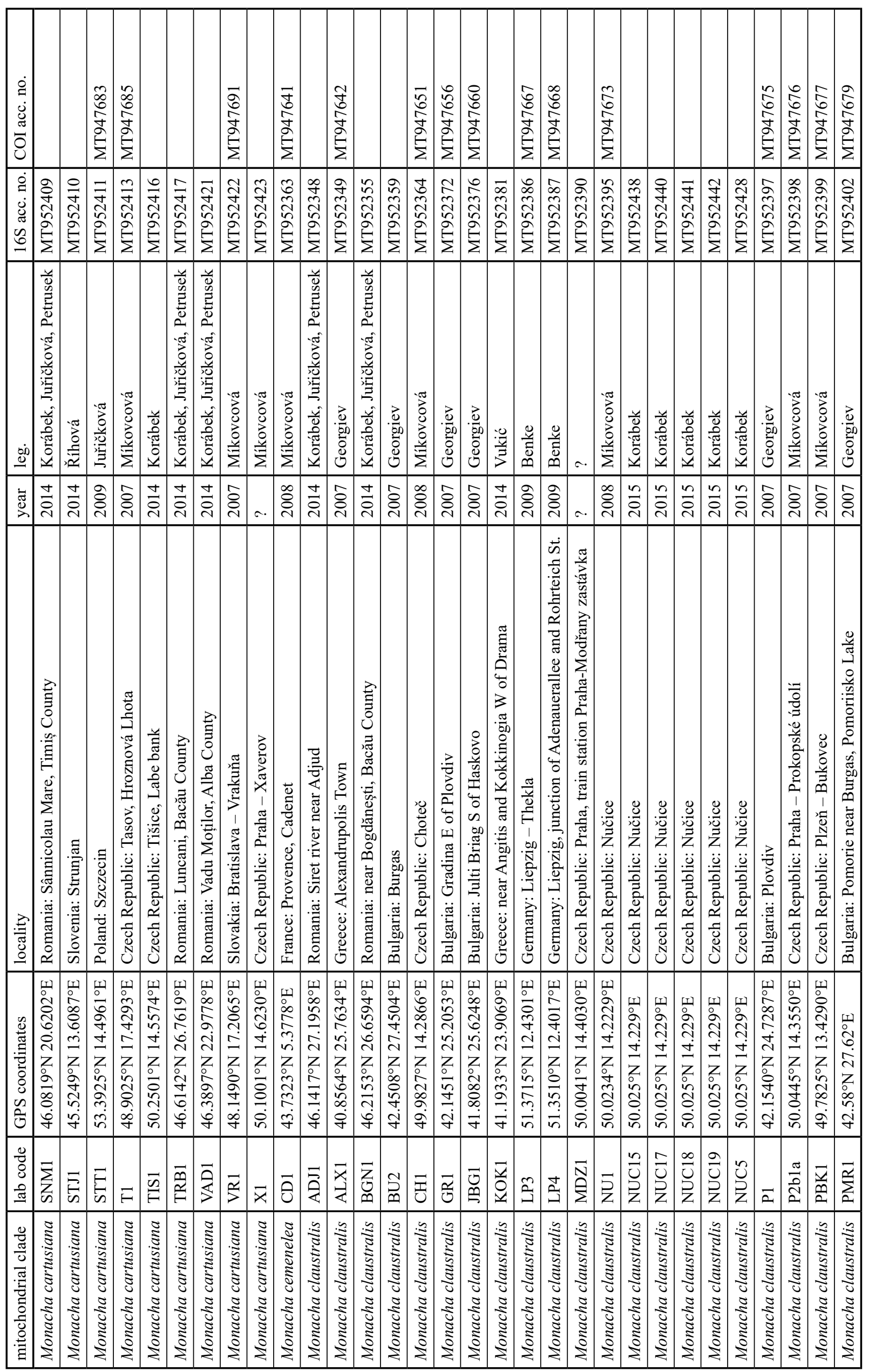




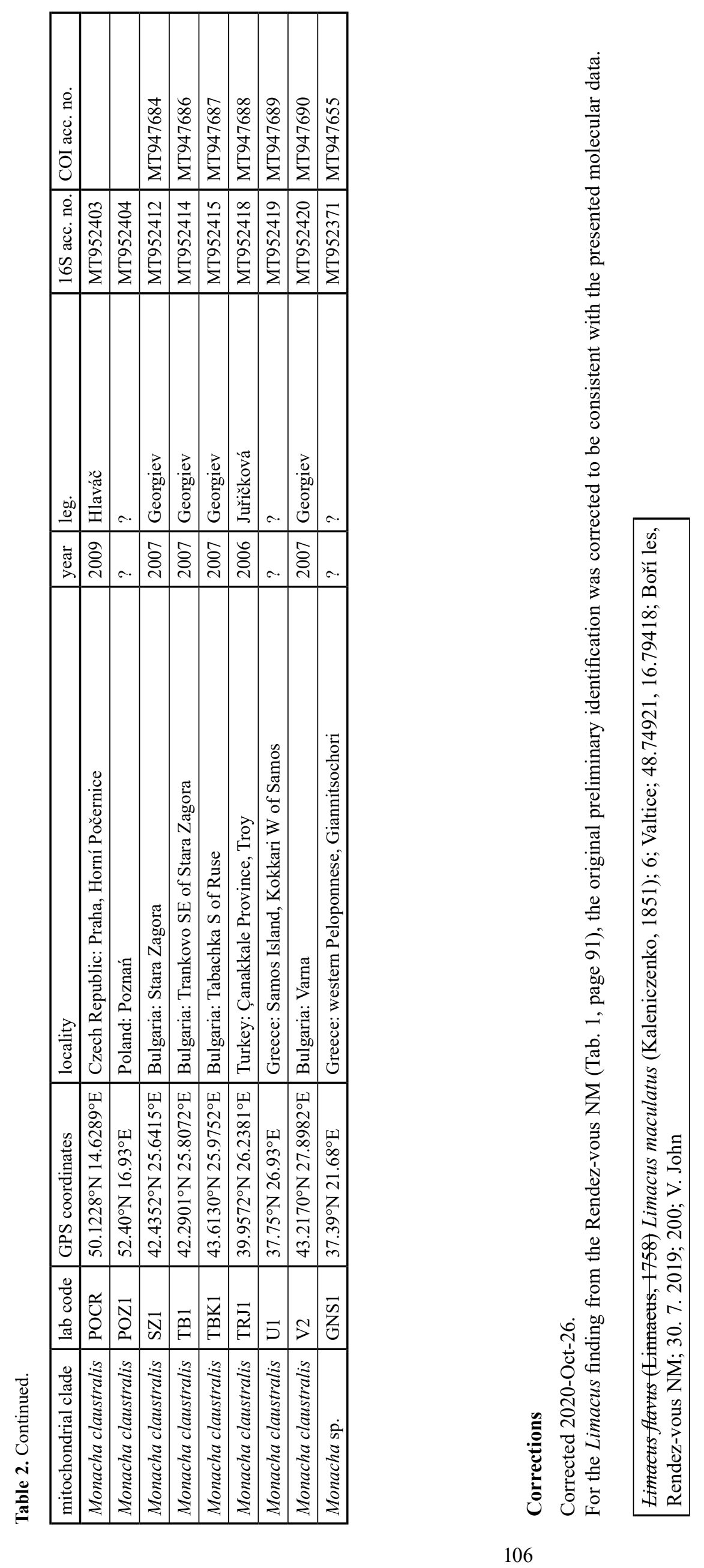

